Sheila Fernandes Pimenta e Oliveira

Vânia de Fátima Martino

Genaro Alvarenga Fonseca

Hilda Maria Gonçalves da Silva (org.)

\title{
Desafios da Gestão Educacional Democrática na Contemporaneidade
}

Coleção Educação e Educandos
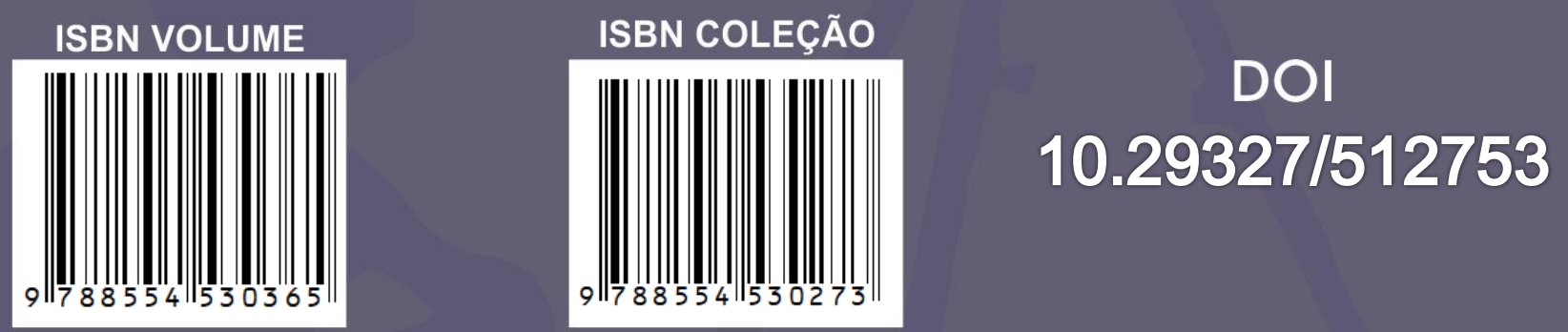


\section{DESAFIOS DA GESTÃO EDUCACIONAL DEMOCRÁTICA NA CONTEMPORANEIDADE}


Vânia de Fátima Martino

Genaro Alvarenga Fonseca

Hilda Maria Gonçalves da Silva (org.)

\section{DESAFIOS DA GESTÃO EDUCACIONAL DEMOCRÁTICA NA CONTEMPORANEIDADE}

ISBN 978-85-5453-036-5

FRANCA

Uni-FACEF/UNESP

2019

Comissão Científica 
Alessandra David (Centro Universitário Moura Lacerda)

Ana Lúcia Furquim Campos-Toscano (Uni-FACEF)

Célia Maria David (UNESP)

Fernando Silva Ribeiro (Universidade Estadual de Goiás)

Genaro Alvarenga Fonseca (UNESP)

Hilda Maria Gonçalves da Silva (UNESP)

Joana Correa Goulart (Universidade Estadual de Goiás)

Karina de Melo Conte (Centro Universitário Claretiano)

Karina Elizabeth Serrazes (Centro Universitário Claretiano)

Lucinda de Fátima Maria Coelho Rodrigues (Uni-FACEF)

Lucimary Bernabé Pedrosa de Andrade (FFCL)

Márcia Pereira da Silva (UNESP)

Maria Eloísa de Souza Ivan (Uni-FACEF)

Maria Madalena Graciloi (FFCL)

Maria Sílvia Pereira Rodrigues Alves Barbosa ((Uni-FACEF)

Pricila Bertanha (Centro Universitário Claretiano)

Sheila Fernandes Pimenta e Oliveira (Uni-FACEF)

Sílvia Regina Viel (Uni-FACEF)

Sílvio Carvalho Neto (Uni-FACEF)

Vânia de Fátima Martino (UNESP)

Tatiana Noronha de Souza (UNESP)

Welton Roberto Silva (Uni-FACEF)

\section{Conselho Editorial}

Ana Cláudia da Silva (UnB)

Antônio Carlos Petean (UFU)

Daniela Melaré Vieira Barros - Universidade Aberta / Portugal

Danilo Seithi Kato (UFTM)

Genaro Alvarenga Fonseca (UNESP)

Sheila Fernandes Pimenta e Oliveira ((Uni-FACEF)

Sílvio Carvalho Neto (Uni-FACEF)

Teise de Oliveira Guaranha Garcia - FFCLRP / USP

Vânia de Fátima Martino (UNESP) 
(C) 2019 dos autores

Direitos de publicação Uni-FACEF

www.unifacef.com.br

Coleção: Educação e Educandos, v.1. 


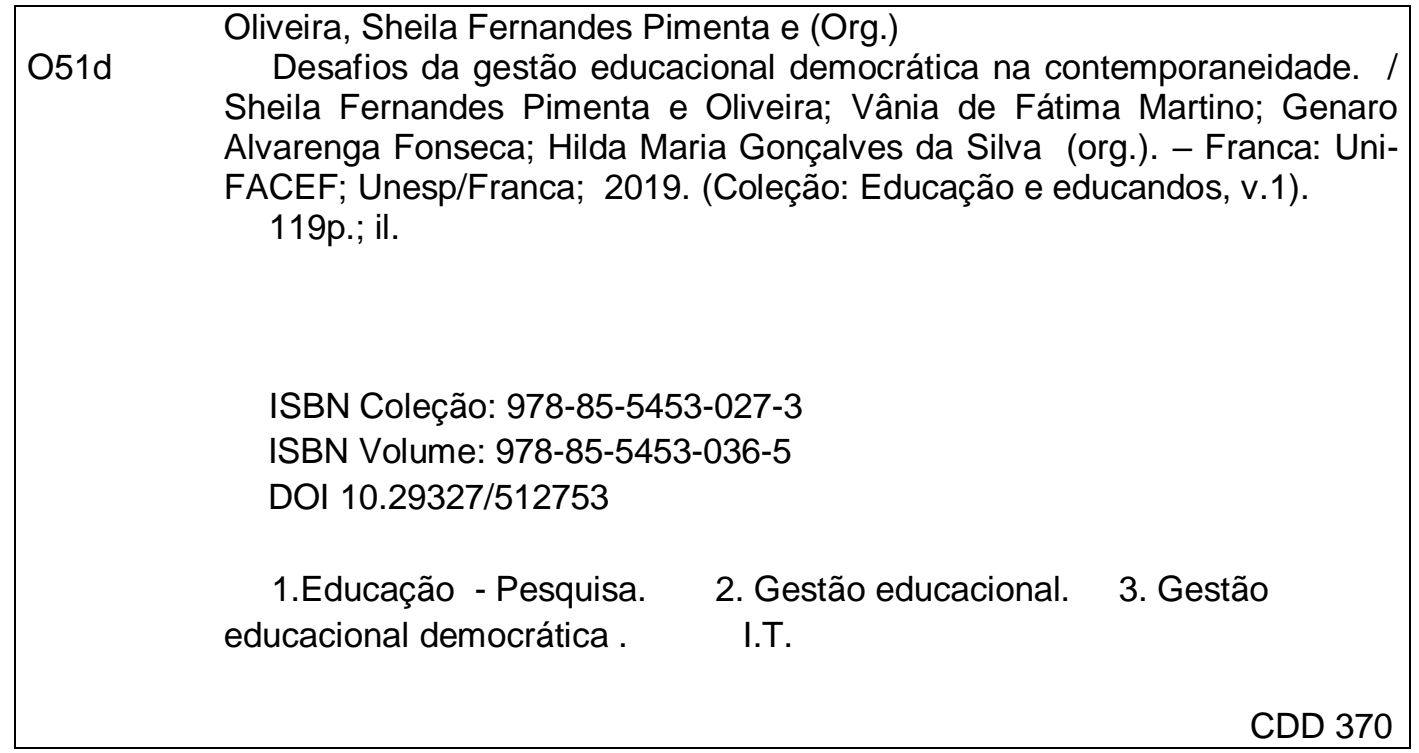

TODOS OS DIREITOS RESERVADOS.

É proibida a reprodução total ou parcial, de qualquer forma ou por qualquer meio. A violação dos direitos de autor (lei no. 9.610/98) é crime estabelecido pelo artigo 184 do código Penal. Todo o conteúdo apresentado neste livro é de responsabilidade exclusiva de seus autores.

Editora Uni-FACEF Centro Universitário Municipal de Franca Associada à ABEC - Associação Brasileira de Editores Científicos 


\section{PREFÁCIO}

O objetivo deste livro é discutir os desafios que se apresentam para a gestão contemporânea da educação. A escola como instituição historicamente construída possui uma gestão que é, ao mesmo tempo, o reflexo desse processo de construção e um esforço no sentido da superação dos desafios postos para a transformação desse espaço. Um olhar atento ao processo histórico de constituição da educação escolar no Brasil permite observar uma instituição que, por décadas, excluiu a população menos favorecida econômica e socialmente e durante anos a fio se caracterizou como elitista.

Foi somente, a partir Constituição de 1988 e nas décadas seguintes, que se passou a enfrentar com maior rigor o desafio do acesso e da permanência na educação básica. É a partir da Carta Magna também que se estabelece a necessidade de envidar esforços no sentido da construção de uma gestão escolar democrática.

Muitos dos entraves daquele contexto, de abertura democrática, estão presentes atualmente nos sistemas educacionais de nosso país. O resultado desses entraves, na dinâmica escolar, tem sido um visível descompasso entre o avanço democrático das últimas décadas e as persistências de um modelo de gestão, majoritariamente técnico-científico, ou tecnocrático. O mais grave dessa prevalência é o pouco apreço dessa tendência de gestão pela qualidade social da educação.

Este livro é o resultado da escolha dos melhores trabalhos, sobre a temática da Gestão Educacional, apresentados no VII Simpósio de Educação e IV Encontro Internacional de Políticas Públicas em Educação. Ótima leitura!

Prof $^{-}$Dr ${ }^{a}$ Hilda Maria Gonçalves da Silva Docente da Faculdade de Ciências Humanas e Sociais Unesp/Franca 


\section{SUMÁRIO}

A GESTÃO ESCOLAR E OS DESAFIOS DA APLICAÇÃO DA PRÁTICA INTERDISCIPLINAR

A MERCANTILIZAÇÃO DO ENSINO SUPERIOR BRASILEIRO COMO PROJETO DE EXCLUSÃO SOCIAL E CONTROLE ESTATAL

ATENDIMENTO EM INSTITUIÇÕES CONVENIADAS DE EDUCAÇÃO INFANTIL: O que apontam as pesquisas na área?

CULTURA E COMPORTAMENTO DE CIDADANIA ORGANIZACIONAL EM AMBIENTES DE ENSINO E APRENDIZAGEM

GESTÃO PÚBLICA E EDUCAÇÃO INFANTIL DE QUALIDADE

MONITORAMENTO E AVALIAÇÃO DE PLANOS MUNICIPAIS DE EDUCAÇÃO: Uma análise dos documentos orientadores nacionais

O LUGAR DO MONITORAMENTO E AVALIAÇÃO NOS PLANOS MUNICIPAIS DE EDUCAÇÃO: O caso da Região Administrativa de Marília/SP.

PARCERIAS INSTITUCIONAIS COM VISTAS À EDUCAÇÃO EMPRESARIAL: Relato da formação da Escola Prática de Negócios no âmbito do Programa de Desenvolvimento Empresarial

PRÁTICAS DE GESTÃO ESCOLAR DA EDUCAÇÃO BÁSICA: a estrutura da equipe gestora escolar da rede pública municipal de ensino em Franca/SP - perspectivas, atribuições e articulação do trabalho

ÍNDICE 


\title{
A GESTÃO ESCOLAR E OS DESAFIOS DA APLICAÇÃO DA PRÁTICA INTERDISCIPLINAR
}

\author{
FINETTE, Carolina Rodrigues \\ Graduanda em História - UNESP/ Franca \\ Carolinafinette@gmail.com \\ SILVA, Hilda Maria Gonçalves da \\ Doutora em Educação Escolar - FCLAR \\ Hilda gs@yahoo.com.br
}

\section{INTRODUÇÃO}

A literatura relacionada à Interdisciplinaridade no meio escolar se esforçou, durante anos, para compreender a legitimidade de sua aplicação, visando estudar se a última seria ou não atendida pela norma, quais são os artigos que a defendiam, qual o papel do professor em seu uso, quais as melhores maneiras de se fazer valer a Interdisciplinaridade e alguns pesquisadores, ainda, se esforçavam em estruturar um conceito mais consensual sobre seu significado. Porém, a literatura acerca do tema carecia de estudos que procurassem entender qual o impacto da gestão escolar, e não apenas dos docentes, na e para a ação Interdisciplinar em sala de aula.

É importante destacar que a influência da gestão na organização do tempo/espaço, nas atividades pedagógicas e na rotina da escola, em geral, também tem sido objeto de estudos de pesquisadores da área da gestão escolar que apontam que a identidade institucional da escola, em especial a sua gestão, está diretamente interligada aos resultados obtidos no aprendizado dos alunos, portanto, era provável que houvesse uma ligação entre gestão escolar e a Interdisciplinaridade como ferramenta pedagógica.

A apreensão de tal influência foi perseguida neste estudo por meio da análise dos documentos legais que tratam das funções da gestão escolar da rede pública do Estado de São Paulo, com especial atenção para as funções do gestor - diretor e coordenador - em relação à organização dos espaços e da rotina de sala de aula, bem como das atividades pedagógicas coletivas. Junto a isso, houve o acompanhamento da rotina da gestão escolar de duas escolas situadas no interior paulista, sendo analisadas quais eram as atribuições desempenhadas por cada um dos membros da gestão da escola, quais os papéis desenvolvidos por eles e quais as dificuldades enfrentadas por esses personagens. 
Além disso, analisou-se a fundo a rotina de cada uma das escolas, como se dava a organização dos processos de ensino e aprendizagem e a organização das atividades de apoio técnico-administrativo, visando compreender se esses fatores contribuíam ou dificultavam a aplicação da prática interdisciplinar na escola. Realizou-se, ainda, uma análise conjunta das condições observadas tanto com relação a gestão escolar como com relação às estruturas e ao ensino nas escolas, visando construir uma análise de caso relativa às duas escolas estudadas. $O$ objetivo dessa análise foi compreender a influência da gestão escolar nas escolas, contrastando com o que era determinado em lei e, dessa forma, traçou-se um panorama de como a gestão escolar influenciava a aplicação da prática interdisciplinar em ambos os casos.

O trabalho foi realizado à luz da bibliografia que versa sobre a temática em pauta, quais sejam: a Interdisciplinaridade e Gestão Escolar, constituindo-se um quadro conceitual baseado especialmente nos estudos de Hilton Japiassu (1976), Jurjo Torres Santomé (1998), Jayme Paviani (2008) e Juares da Silva Thiesen (2008). Foi analisada a utilização da Interdisciplinaridade no contexto escolar, por meio de uma investigação dos documentos de cunho legal que versam sobre a ocupação da gestão escolar. Efetuou-se uma comparação entre esses documentos e a rotina dos diretores e dos coordenadores com relação à organização do espaço da unidade, da rotina dentro das salas de aula e das atividades pedagógicas coletivas; de forma a determinar a ligação entre a gestão escolar, a prática interdisciplinar e o que é proposto na legislação estatal.

Portanto, o objetivo do trabalho aqui exposto foi compreender o alcance e as barreiras enfrentadas pelos membros da gestão escolar no emprego da Interdisciplinaridade dentro do ensino, em especial nos anos finais do Ensino Fundamental. A partir da investigação do tema, se buscou contribuir de forma significativa para os estudos no âmbito da Educação, de forma a aprofundar o debate sobre a Interdisciplinaridade e sua aplicação do contexto do ensino.

\section{A Gestão Escolar e a Interdisciplinaridade}

A literatura

A interdisciplinaridade possui múltiplas definições e aplicações. No trabalho aqui exposto, ela é tratada no meio educacional. Segundo Hilton Japiassu, existe a necessidade de se refletir acerca da fragmentação dos conhecimentos e quais são suas consequências para a formação do aluno, já que se encontra presente uma especialização dos conhecimentos científicos e uma ruptura das disciplinas, tornando o ensino fragmentado principalmente a 
partir do século XIX. Para ele, trabalhar a ação interdisciplinar não denota negar a objetividade de cada área do conhecimento, muito menos anular as disciplinas, mas sim, "interdisciplinaridade se caracteriza pela intensidade das trocas entre os especialistas e pelo grau de integração real das disciplinas, no interior de um projeto específico de pesquisa" (JAPIASSU, 1976, p. 74).

Portanto pode-se afirmar que alguém está diante de um empreendimento interdisciplinar quando ele:

conseguir incorporar os resultados de várias especialidades, tomar de empréstimo de outras disciplinas certos instrumentos e técnicas metodológicas, fazendo uso dos esquemas conceituais e análises que se encontram nos diversos ramos do saber, a fim de fazê-los integrarem e convergirem, depois de terem sido comparados e julgados (JAPIASSU, 1976, p. 75).

Por sua vez, Jurjo Torres Santomé afirma que “... alunos e alunas com uma educação mais interdisciplinar estão mais capacitados para enfrentar problemas que transcendem os limites de uma disciplina concreta e para detectar, analisar e solucionar problemas novos" (SANTOMÉ, 1994, p. 74).

Dessa forma, o autor discute a necessidade de uma prática interdisciplinar para a melhoria da formação do aluno, tornando-o mais plural e capaz de encontrar novos desafios. Além disso, destaca a necessidade de uma intervenção educativa mais aberta, dialógica, que propicia o exercício do protagonismo, tanto no ato de aprender como no ato de ensinar, uma maior abertura do canal de comunicação entre os atores sociais que constroem o cenário curricular, maior possibilidade de trabalho, análise e interpretação dos conteúdos culturais. Juares da Silva Thiesen destaca algo parecido:

[...] quanto mais interdisciplinar for o trabalho docente, quanto maiores forem as relações conceituais estabelecidas entre as diferentes ciências, quanto mais problematizantes, estimuladores, desafiantes e dialéticos forem os métodos de ensino, maior será a possibilidade de apreensão do mundo pelos sujeitos que aprendem (THIENSEN, 2008).

Por outro lado, Jayme Paviani afirma que a interdisciplinaridade atua como uma ferramenta de mediação entre a homogeneização e a pluralidade, onde o objetivo não seria acabar com as especificidades das matérias ou das disciplinas, mas de permitir, no atual estágio de complexidade do desenvolvimento dos conhecimentos, conjugar os conhecimentos necessários para resolver os problemas científicos.

Portanto, uma ação interdisciplinar aplicada no ensino público seria capaz de potencializar a apreensão dos conteúdos por parte dos alunos já que, a partir dela, haveria a formulação de novos problemas, mais 
estimulantes e desafiadores, além de oferecer ao sujeito a oportunidade de ser protagonista do seu próprio processo educativo.

Tendo em vista que o principal propósito da Gestão Escolar é prover a efetivação da formação do aluno, integrando esses conhecimentos a sua vivência e a comunidade, conclui-se que a Interdisciplinaridade é uma ferramenta capaz de englobar essas necessidades, desde que haja possibilidade de sua implantação, por meio de um maior diálogo entre os educadores e gestores, a utilização de métodos e instrumentos de outras disciplinas, além do empréstimo de outras formas de análise presente em outros campos do saber. Cabe, portanto, a Gestão Escolar incentivar essas trocas, seja na promoção de projetos específicos, seja ao permitir aulas conjuntas. Porém, durante a realização do trabalho aqui exposto, ficaram claras as dificuldades que a gestão escolar enfrenta na promoção da Interdisciplinaridade.

\subsection{A legislação educacional}

A Secretaria Estadual de Educação de São Paulo (SEE-SP), na Resolução SE 56, de 14-10-2016, "Dispõe sobre perfil, competências e habilidades requeridos dos Diretores de Escola da rede estadual de ensino" (SEE-SP, 2016). Nesse documento, estão listadas cento e vinte e cinco competências esperadas dos diretores da rede estadual de ensino, indicando de antemão a multiplicidade de tarefas sob responsabilidade desses atores. Entre elas:

Conhecimento de:

* Diretrizes curriculares nacionais.

[...] * Teorias de aprendizagem e de desenvolvimento.

* Abordagens do processo de ensino e aprendizagem.

* Referencial teórico-prático de monitoramento, observação e gestão da sala de aula e de processos de intervenção pedagógica.

* Estratégias para apoiar e intervir na gestão em sala de aula.

(SEE-SP, 2016)

Dessa forma, a legislação estadual determina o envolvimento da Gestão Escolar nos processos de aprendizagem, na gestão dentro de sala de aula e na aplicação das diretrizes curriculares nacionais, tais como a BNCC. A 
última determina em seu seio a utilização da metodologia interdisciplinar, como segue:

\begin{abstract}
É referendada em documentos oficiais propostos pelo Ministério da Educação, como na já citada BNCC (BRASIL, 2016) e nas Diretrizes Curriculares Nacionais para a Formação de Professores da Educação Básica, em nível superior (BRASIL, 2002). Podemos perceber que os documentos oficiais apresentam a interdisciplinaridade como objetivo [...] (MACKEDANZ; ROSA, 2016).
\end{abstract}

Portanto, a utilização da metodologia interdisciplinar pelos gestores no estado de São Paulo é prevista por lei, porém pouco se fala sobre o seu uso e tampouco são instruídas aos sujeitos as maneiras de sua aplicação na gestão escolar, já que "[...] os documentos oficiais [...] se isentam de definila, o que não auxilia no sentido de construir abordagens verdadeiramente interdisciplinares para a educação." (MACKEDANZ; ROSA, 2016).

Conclui-se, dessa maneira, que embora a Interdisciplinaridade seja prevista tanto nas legislações nacionais como do Estado de São Paulo, ela não é incentivada, seja pelo seu desconhecimento, seja pela falta de recursos ou então pelo acumulo excessivo de responsabilidades atribuídas aos gestores.

\title{
1.2. A rotina escolar
}

Foi realizado um estudo de campo acompanhando duas escolas no interior paulista, pelo período de seis meses, a fim de observar a rotina pedagógica e administrativa enfrentada pelos gestores escolares. Durante esse período, notou-se a complexidade que envolve a práxis dos gestores, já que existem diversos fatores contraditórios entre as normativas a serem executadas e as condições existentes para sua realização. Segundo os agentes das escolas, essas dificuldades ocorrem por múltiplas razões: falta de formação especifica para os cargos de gestão, falta de formação continuada, falta de recursos, falta de apoio da Gestão Educacional, etc.

Além desses fatores, ainda há queixas constantes de uma grande acumulação de atribuições a serem desempenhadas por um grupo seleto de atores na gestão, que normalmente é composta apenas por um diretor, um vice-diretor e um coordenador pedagógico, como destaca Heloísa Lück:

A gestão escolar constitui uma das áreas de atuação profissional na educação destinada a realizar o planejamento, a organização, a liderança, a orientação, a mediação, a coordenação, o monitoramento e a avaliação dos processos necessários à efetividade das ações educacionais orientadas para a promoção da aprendizagem e formação dos alunos (LÜCK, 2009, pg. 23) 
Fora isso, se aplica a falta de sincronia entre o trabalho de Gestão Escolar (direção e coordenação pedagógica) e o da Gestão Educacional (coordenadorias e secretarias de educação), já que, em diversos casos, relatou-se o desconhecimento dos gestores educacionais com relação a realidade das escolas e de seus membros ativos, muitas vezes impondo normativas consideradas, pelos integrantes da escola, como incoerentes e ineficazes.

Em conjunção, ainda há a divisão dos campos do saber em disciplinas específicas e estruturadas no currículo de forma a dificultar a ação interdisciplinar, colocando conteúdos muito passíveis de conexão em momentos diferentes do calendário escolar. Essa divisão das áreas do conhecimento está presente no Currículo do Estado de São Paulo e durante sua elaboração a ação interdisciplinar não se encontra presente, apesar do documento inclusive citar a Base Nacional Curricular Comum como base do documento, como segue: "As aprendizagens que devem ser garantidas aos alunos são organizadas em áreas do conhecimento (Linguagens, Matemática, Ciências da Natureza, Ciências Humanas e Ensino Religioso), obedecidas as determinações da legislação vigente, inclusive as da BNCC." (SEE-SP, 2019).

Portanto, a junção do excesso de tarefas com a falta de tempo, de recursos, de organização de formação e principalmente, a falta de defesa da Interdisciplinaridade nas legislações do Estado de São Paulo, tornaram a ação interdisciplinar relegada ou até mesmo pouco conhecida pelos gestores de ambas as escolas, que embora sempre estivessem dispostos a desenvolver uma boa prática educacional, em nenhum momento citaram ou realizaram qualquer atividade voltada a prática Interdisciplinar. As poucas experiências que se aproximaram de uma prática interdisciplinar na verdade foram multidisciplinares pois os professores definiam um tema comum e, na sequencia, cada docente abordava de maneira solitária o enfoque de sua disciplina relacionada ao tema escolhido.

\section{Considerações Finais}

A partir da análise das leituras, do confrontamento entre dados e observações do processo de educação e de gestão escolar se buscou, por meio desse projeto, compreender como se dá a relação entre Gestão Escolar e Interdisciplinaridade, seja ela facilitadora ou de empecilho, dando enfoque particular nos anos finais do Ensino Fundamental. Além disso se visou expandir os conhecimentos sobre 0 tema, ampliando os saberes sobre Interdisciplinaridade para além da influência dos docentes, compreendendo como o corpo gestor da unidade escolar, em especial diretores e 
coordenadores, também são capazes e responsáveis pela empregabilidade da Interdisciplinaridade.

A partir da leitura da bibliografia, da análise da legislação estadual e nacional acerca da gestão escolar e da interdisciplinaridade e também por meio do trabalho de campo em duas escolas estaduais no interior paulista, visou-se esclarecer que o papel de utilização da ação interdisciplinar não se limita aos professores, mas também deveria incluir os membros da administração do núcleo escolar. Porém, conclui-se que existem diversos empecilhos enfrentados diariamente pela gestão escolar para o incentivo e a aplicação da prática interdisciplinar na escola como, por exemplo: falta de recursos financeiros, acumulo intensivo de atribuições, normativas contraditórias advindas dos órgãos de gestão educacional, falta de formação inicial e continuada, etc. Esses obstáculos infelizmente contribuem para inaplicação da prática interdisciplinar no ensino público do Estado de São Paulo.

\section{REFERÊNCIAS}

BRASIL. Base Nacional Comum Curricular. Brasília: MEC, 2017. Disponível em: http://basenacionalcomum.mec.gov.br/abase/. Acesso em: 21 de agosto de 2019.

FAZENDA, Ivani (org.). Interdisciplinaridade: Dicionário em Construção. $2^{\underline{a}}$ Edição. São Paulo, SP: Cortez Editora, 2001.

FAZENDA, Ivani. Integração e interdisciplinaridade no ensino brasileiro. $4^{\circ}$ Edição. São Paulo: Loyola, 1996.

JAPIASSU, Hilton. A atitude interdisciplinar no sistema de ensino. Ver. Tempo Brasileiro, Rio de Janeiro, n. 108, p. 83 - 94, janeiro-março., 1992.

JAPIASSU, Hilton. Interdisciplinaridade e patologia do saber. Rio de Janeiro, RJ: Imago, 1976.

LIBÂNEO, J.C; OLIVEIRA, J. F; TOSCHI, M.S. Educação Escolar: políticas, estrutura e organização. $9^{\circ}$ Edição. São Paulo, SP: Cortez Editora, 2003.

LÜCK, Heloísa. Dimensões da gestão escolar e suas competências. Curitiba: Positivo, 2009.

LÜCK, Heloísa. Gestão Educacional: Uma questão paradigmática. $10^{\circ}$ Edição. Petrópolis, RJ: Vozes, 2013.

LÜCK, Heloísa. Pedagogia Interdisciplinar: Fundamentos TeóricoMetodológicos. 13를 edição. Petrópolis, RJ: Vozes, 2005. 
MACHADO, Maria Aglaê de Medeiros. A Gestão da Escola Básica: conhecimento e reflexão sobre a prática cotidiana da diretora de escola municipal. Em Aberto. Brasília, DF. V. 17, n. 72, p. 71-87, fev./jun. 2000.

MACKEDANZ, Luiz Fernando; ROSA, Liane Serra da. O discurso da interdisciplinaridade $e$ as impressões docentes sobre o ensino de Ciências Naturais no Ensino Fundamental. Rev. Thema, v. 13, n.3, p. 140-152, 2016. Disponível em: http://dx.doi.org/10.15536/thema.13.2016.140-152.392. Acesso em 15 de agosto de 2019.

MEIHY, J. C. S. B. Manual de História oral. $4^{\circ}$ Edição. São Paulo, SP: Edições Loyola, 2002.

OLIVEIRA, Dalila Andrade (Org.). Gestão democrática da educação: Desafios contemporâneos. 11 Edição. Petrópolis, RJ: Vozes, 2015.

PARO, Vitor Henrique. Gestão democrática da escola pública. $4^{\circ}$ Edição. São Paulo, SP: Cortez Editora, 2016.

PAVIANI, Jayme. Interdisciplinaridade: Conceitos e distinções. $2^{\circ}$ Edição. Caxias do Sul, RS: Educs, 2008.

PLACCO, Vera Maria Nigro de Souza; ALMEIDA, Laurinda Ramalho de Almeida (org.). O coordenador pedagógico e o cotidiano escolar. $8^{\circ}$ Edição. São Paulo, SP: Edições Loyola, 2003.

SANDER, Benno. Políticas Públicas e Gestão Democrática da Educação. Brasília, DF: Liber Livro, 2005.

SANTOMÉ, Jurjo Torres. Globalização e Interdisciplinaridade: O currículo integrado. Porto Alegre, RS: Artmed, 1998.

SECRETARIA DA EDUCAÇÃO DO ESTADO DE SÃO PAULO. Dispõe sobre perfil, competências e habilidades requeridos dos Diretores de Escola da rede estadual de ensino, e sobre referenciais bibliográficos e legislação, que fundamentam e orientam a organização de concursos públicos e processos seletivos, avaliativos e formativos, e dá providências correlatas. Resolução n. 56, de 14 de outubro de 2016. Disponível em: http://siau.edunet.sp.gov.br/ItemLise/arquivos/56 16.HTM?Time=04/09/2019\% 2013:08:10. Acesso em 01 de agosto de 2019.

SECRETARIA DA EDUCAÇÃO DO ESTADO DE SÃO PAULO. Homologando, com fundamento no artigo $9^{\circ}$ da Lei 10.403, de 6-7-1971, a Deliberação CEE 169/2019, que "Fixa normas relativas ao Currículo Paulista da Educação Infantil e Ensino Fundamental para a rede estadual, rede privada e redes municipais que possuem instituições vinculadas ao Sistema de Ensino do Estado de São Paulo, e dá outras providências". Resolução, de 06 de agosto de 2019. Disponível

em: 
http://siau.edunet.sp.gov.br/ItemLise/arquivos/38 19.HTM?Time=04/09/2019\% 2015:13:05. Acesso em 22 de agosto de 2019.

THIESEN, Juares da Silva. A interdisciplinaridade como um movimento articulador no processo ensino-aprendizagem. Rev. Bras. Educ., Rio de Janeiro, v. 13, n. 39, p. 545-554, Dec. 2008. Disponível em: http://www.scielo.br/scielo.php?script=sci arttext\&pid=S1413-

24782008000300010\&lng=en\&nrm=iso . Acesso em 13 de abril de 2019. 


\title{
A MERCANTILIZAÇÃO DO ENSINO SUPERIOR BRASILEIRO COMO PROJETO DE EXCLUSÃO SOCIAL E CONTROLE ESTATAL
}

\author{
DIAS, Matheus Henrique \\ Graduando em Direito - Faculdade de Direito de Franca \\ matheusdiasfdf@outlook.com \\ TOFFANO, Marcelo \\ Doutor em Direito - Faculdade de Direito de Franca \\ prof.toffano@gmail.com
}

\section{Introdução}

A Educação é direito humano fundamental que alcança a consciência social, a percepção coletiva da realidade, o pensamento político e o conhecimento crítico, além disso, tem proteção no ordenamento jurídico brasileiro na Constituição Federal de 1988, na Lei de Diretrizes e Bases da Educação n 9.394/96 e no Plano Nacional de Educação em Direitos Humanos.

A evolução humana com a conscientização e libertação dos oprimidos e opressores somente são possíveis com o desenvolvimento da Educação democrática, inclusiva, livre e crítica que cumpre, assim, o exercício efetivo da cidadania por constituir direito do povo e dever do Estado (FREIRE, 2019).

As características citadas devem estar presentes em todos os níveis do aprendizado, mas a pesquisa se concentrará no ensino superior brasileiro, especialmente sobre as graduações, como fonte de estudos.

No mesmo sentindo, conforme o entendimento de Elias de Oliveira Motta, a Educação é um processo de humanização e capacitação:

\begin{abstract}
A Educação constitui-se, portanto, no processo pelo qual o ser humano, por um lado, adquire conhecimentos e desenvolve sua capacidade intelectual, sua sensibilidade afetiva e suas habilidades psicomotoras. Por outro lado, é também o processo pelo qual ele transmite tudo isso a outra pessoa. A educação engloba, pois, de forma indissociável, tanto os processos de aprendizagem quanto os de ensino e, envolve, normalmente, dois interlocutores, o educando e educador, ou o educando e algum meio educativo. Dessa forma, a Educação se confunde com o próprio processo de humanização. Pois é a capacitação do indivíduo tanto para viver civilizadamente e produtivamente, quanto para formar seu próprio código de comportamento e para agir coerentemente com seus princípios e valores, com abertura para revisá-los e modificar seu comportamento quando mudanças se fizerem necessárias (MOTTA, 1997).
\end{abstract}


A universidade como instituição tem impacto direto na sociedade com sua produção acadêmica e profissional ao transformar os conhecimentos em ciências, os conhecimentos críticos, e exprimir as divergências de opiniões, atitudes e projetos que constroem a dialética indispensável para o progresso da comunidade.

\begin{abstract}
Essa relação interna ou expressiva entre universidade e sociedade é o que explica, aliás, o fato de que, desde seu surgimento, a universidade pública sempre foi uma instituição social, isto é, uma ação social, uma prática social fundada no reconhecimento público de sua legitimidade $e$ de suas atribuições, num princípio de diferenciação, que the confere autonomia perante outras instituições sociais, e estruturada por ordenamentos, regras, normas e valores de reconhecimento e legitimidade internos a ela (CHAUÍ, 2003).
\end{abstract}

A definição como instituição social deve ser entendida como um bem público e gratuito, a redundância é importante devido aos processos de mercantilização, fulcro deste trabalho, e sucateamento, que estão em cursos, para a redefinição como organização social, na qual os detentores do poder buscam atrofiar suas virtudes.

A inserção da Educação como setor de serviços no Acordo Geral sobre Comércio de Serviços da Organização Mundial do Comércio, a falta de regulação das universidades privadas devido ao interesse do Estado brasileiro na exclusão social e controle impositivo arbitrário, as crises da universidade, 0 financiamento das políticas sociais indicam que a Educação concebida como direito passou a ser tratada como serviço aos interesses particulares e com isso é considerada como organização social que adiante será explicada (CHAUÍ, 2003; LAVINAS, 2017; RIBEIRO, 2006; SANTOS, 2011).

As universidades se tornam instituições financeiras sem compromisso com o projeto pedagógico e a qualidade, assim, o tripé ensino, pesquisa e extensão são alterados para excesso de alunos, falta de autonomia dos professores com baixos salários e o fator determinante do lucro.

O mercado educacional com o setor universitário privado tem campo de atuação abrangente e vantajoso em países que o Estado se afasta de suas responsabilidades constitucionais e incentiva a mercantilização com projetos que interferem na autonomia universitária, como o "Programa Institutos e Universidades Inovadoras" - Future-se para as universidades federais brasileiras.

A reconfiguração nas características de uma universidade era perceptível apenas nas universidades privadas com campis sinônimos de franquias que buscam apenas a produtividade, entretanto a atual conjuntura política brasileira com a eleição de Jair Bolsonaro estendeu o problema para as universidades públicas. 
A mercadorização universitária é reforçada em um momento de desrespeitos aos ideais democráticos e princípios humanos e, além disso, a negação do conhecimento pelos próprios governantes comprovando o projeto de exclusão social e controle do Estado de características autoritárias, fascistas e opressoras com a redução do espaço universitário que deve ser público e livre, a exclusão de pessoas do acesso às universidades e a participação democrática das organizações estudantis.

Brunner e Uribe entendem que cada sistema de ensino superior efetua seu caminho em direção a mercantilização e por isso é impossível citarmos um procedimento único, mas algo plural com diferentes e diversas formas de se atingir o deslocamento, de acordo com os autores um conjunto de condições produzidas nos contextos nacionais, tais como o desenvolvimento dos sistemas de ensino superior, as medidas de políticas utilizadas pelos governos e as estratégias das instituições diante das forças de mercado, como, por exemplo, na disputa pela alocação de recursos, como o Future-se, supracitado, ou ainda a avaliação de sua efetividade (SAMPAIO apud BRUNNER e URIBE, 2007).

A sociedade crítica, livre e inclusiva somente é possível com a valorização da Educação em um sistema justo, democrático e igualitário, que deve se opor ao controle social impositivo arbitrário de natureza ilegal, imoral, injusta e arbitrária que tem indícios no projeto de privatização pelo atual governo brasileiro.

O direito à Educação em conjunto com o dever do Estado ao acesso, examinados em capítulo específico, são valores constitucionais que devem ser dotados de financiamento público para a indispensabilidade como garantia ao povo, entretanto 0 processo de mercantilização afasta a responsabilidade estatal na prestação do ensino em benefício da lucratividade das empresas.

\section{CONHECIMENTO COMERCIALIZADO}

Para desenvolvermos a problemática do trabalho, em primeiro lugar, deve-se explicar o conceito de mercadorização ou mercantilização como sendo o processo de transformação de coisas ou bens que não possuem a essência de mercadorias em sujeitos do mercado.

O Brasil, contexto da pesquisa, iniciou o processo de mercantilização da Educação com a Reforma Universitária de 1968 quando o Estado expandiu a rede privada e teve papel decisivo para levar adiante esse crescimento com duas práticas: investimento público em formas de subsídios e 
redução dos impedimentos legais para a criação de novos cursos, ambos para o comércio do saber (LOPES; VALLINA apud FASUBRA, 1988).

\begin{abstract}
Nesse cenário, enquanto o setor privado se expandia por meio da criação de instituições isoladas e do aumento do número de vagas, cursos/carreiras, o setor público, formado quase exclusivamente por universidades, investia em estruturas de pesquisa e de regulação e apoio à pós-graduação (SAMPAIO; KLEIN, 1994).
\end{abstract}

Percebe-se que nesse período o crescimento exponencial do número de matrículas no setor universitário privado brasileiro foi de quase $500 \%$, deslocando, assim, o foco do governo no tratamento entre os setores ao preferir reduzir o investimento no setor público e intensificar a concorrência entre as empresas educacionais, enquanto as universidades públicas visavam a qualidade pela pesquisa, as universidades privadas focavam na quantidade exorbitante do número de matrículas (SAMPAIO, 2000).

O mercado, com isso, enxergou a Educação como campo de atuação abrangente e extremamente lucrativo e em meados de 2000, a Organização Mundial do Comércio inseriu o ensino, em todos os níveis, como um dos dozes serviços abrangidos pelo Acordo Geral sobre Comércio de Serviços (GATS) com o objetivo de promover a liberalização do comércio deste "serviço" com a eliminação das barreiras comerciais (SANTOS, 2011).

A Comissão do Conselho de Cultura e Extensão da Universidade de São Paulo em 2003 publicou um relatório sobre a inclusão do ensino no GATS e listou as principais consequências: desnacionalização do setor, acirramento da competividade, prejuízo para os pequenos e médios empreendimentos e agravamento do quadro de diferenças regionais (RIBEIRO, 2006).

Boaventura de Sousa Santos distinguiu em quatro modos as ofertas previstas no GATS: oferta transfronteiriça, consumo de estrangeiro, presença comercial e presença de pessoas (SANTOS, 2011).

As descapitalizações dos governos brasileiros, de espectros políticos de direita ou de esquerda, somada a transnacionalização do tratado de liberalização da Organização Mundial do Comércio formaram as chamadas "universidades mercantis", como sinônimos de organização social e instituição financeira.

[...] as universidades particulares com explícitos fins lucrativos, geridos enquanto empresas educacionais, oferecendo produtos e serviços de acordo com a demanda do mercado, instituições estas que denominamos universidades mercantis [...] 0 mercado de oferta encontra-se representado pela grande diversificação de produtos e serviços, colocados no mercado por universidades com os mais variados perfis e missões institucionais (CALDERÓN, 2000). 
A reformulação da universidade como serviço a produção mercantil afasta o papel primordial de relacionar com a cultura, cidadania e formação da identidade nacional e, além disso, alteram-se o conceito e a função como instituição social, corroborando, assim, os ensinamentos de Marilena Chauí sobre os perigos de transmudar a essência de uma universidade (CASTELLS, 1994).

Percebe-se que a educação superior sofre um processo tanto de reformulação conceitual quanto de redução de suas funções sociais. No primeiro caso, a reformulação se dá quando se considera a educação como um serviço, regulado pelas regras gerais do comércio, construídas no âmbito da OMC. Quanto ao segundo aspecto, a redução ocorre quando se entende que a prioridade da educação superior consiste na formação das competências necessárias para o mercado de trabalho. Instalase o discurso de que, na sociedade do conhecimento, o papel da educação superior é central ao processo de desenvolvimento econômico, mas essa centralidade se refere à necessidade da educação superior atender, prioritariamente, senão exclusivamente, às demandas do setor produtivo. Tratase, portanto, de um discurso cuja ênfase recai numa visão exclusivamente mercantil e economicista da educação (BORGES, 2009).

De acordo com Boaventura de Sousa Santos na obra "A Universidade no século XXI: para uma reforma democrática e emancipatória da Universidade", a mercadorização que transforma as propriedades de bem público e direito humano fundamental consiste em dois níveis.

O primeiro nível que trataremos é o da eliminação da distinção entre universidade pública e privada, assim, constitui a universidade mercantil com características de empresa que não produz para o mercado, mas produz a si mesmo como mercado: de gestão universitária, de planos de estudos, de certificação, de formação, de docentes, de avaliações (SANTOS, 2011).

Segundo o Censo da Educação Superior de 2012, aproximadamente sete milhões de estudantes estavam no ensino superior no Brasil com concentração de $75 \%$ nas universidades privadas, comprovando, assim, a consolidação do ensino como mercado, na qual a maioria esmagadora se encontra em espaços que despreza a função social e de formação do ensino superior (SAMPAIO, 2000).

A explosão da comercialização no Brasil aconteceu após a criação dos programas federais de políticas sociais: ProUni (Programa Universidade para Todos) com a isenção de impostos às universidades privadas em troca de bolsas de estudos e FIES (Fundo de Financiamento Estudantil) com os créditos de financiamento público.

Embora ambos os programas financiem estudantes e não instituições, é evidente o impacto deles para a manutenção do 
crescimento das taxas de matrículas nas instituições privadas e, logo, para a sustentabilidade da expansão do setor privado no qual um terço de estudantes é hoje beneficiário do Prouni e do Fies (SAMPAIO, 2000).

O acesso dos estudantes ao ensino superior se tornou realidade social com a instauração e desenvolvimento destes programas, como será citado no próximo capítulo, porém o financiamento do ensino superior brasileiro sofreu desequilíbrio considerável e no período de 2012 a 2017, por exemplo, o crescimento do FIES foi de 181\%, enquanto o das IFES (Instituições Federais de Ensino Superior) foi apenas de 42\% (SIAFI, 2017).

O crescimento desproporcional não é verificado como somente a expansão do financiamento público nas universidades mercantis, mas como prejuízo na destinação de verbas para as universidades públicas (ANDRADE, 2017).

As universidades públicas não foram esquecidas completamente e programas como o "Ciências sem Fronteiras" criado em 2011 concederam milhares de bolsas para pesquisa internacional com apoio de órgãos como Coordenação de Aperfeiçoamento de Pessoal de Nível Superior (CAPES) e Conselho Nacional de Desenvolvimento Científico e Tecnológico (CNPq), entretanto em 2017 o Ministério da Educação encerrou o programa com argumentos de crise econômica e por isso não haveria fundos de investimentos, entretanto os valores bilionários de isenções fiscais com 0 Simples Nacional, Imposto de Renda da Pessoa Física, Zona Franca de Manaus, renúncias nas áreas de agricultura e agroindústria só aumentam.

A política educacional brasileira adotada é de custear os programas de estudantes em IES (Instituições de Ensino Superior) privadas como processo de mercantilização da sociedade tendo o Estado como garantidor dos empréstimos e isenções, porém a taxa de inadimplência de 51,4\% divulgada pelo Ministério da Educação em 2017 mostra que o problema não se encontra apenas na baixa qualidade do ensino privado, mas também com mais da metade do dinheiro investido no programa não retornar aos cofres públicos (LAVINAS, 2017).

A democratização e acesso ao conhecimento pelos programas não são questões levantadas pela pesquisa e o que se pretende é buscar com os dados e fatos como a relação da mercantilização do ensino através dos sujeitos envolvidos com o objetivo principal de lucrar afasta completamente o sentido da entrada em uma universidade para a qualificação profissional.

O governo o faz, ou por estar alinhando com os interesses dos agentes econômicos quando mais liberal, ou por ter o objetivo socialdesenvolvimentista de criar uma sociedade de consumo de massa através do acesso às finanças. Os agentes econômicos porque lucram com 0 endividamento da sociedade e o apoio para desenvolvimento de suas atividades. A população, por sua vez, entende que benefícios são positivos e defende tais propostas como no caso dos beneficiários do PROUNI (ANDRADE, 2017).

O diploma não resume a graduação, cita-se somente esse nível de pela falta da pós-graduação na maioria das universidades mercantis, mas ao processo de aprendizado teórico e prático do estudante com o tripé pesquisa, ensino e extensão. O papel da conclusão da graduação, em muitos 
casos, quando apresentado em um processo seletivo para uma vaga de emprego é desrespeitado devido à procedência de uma universidade reconhecida pelo excesso de alunos, descaso trabalhista com os docentes, inexistência de pesquisa e extensão, completa falta de estrutura dentro das salas de aulas e modalidade ineficaz de ensino.

O resultado imediato após a criação dos programas de financiamento estudantil, aumento da lucratividade, explosão de matrículas, descaso trabalhista, transnacionalização do ensino, descapitalização das universidades públicas é representado pelo maior grupo educacional do mundo estar situado no Brasil, a empresa Kroton com fusões e aquisições alcançou o valor de mercado de $\mathrm{R} \$ 27.6$ bilhões em 2016 (ANDRADE apud LAVINAS, 2017).

O outro nível citado por Boaventura dos Santos é o de induzir a universidade pública a enfrentar a crise financeira com a gestão de receitas próprias com parcerias comerciais e privatizando serviços (SANTOS, 2011).

O programa "Future-se", apresentado pelo governo federal brasileiro em 2019, aprofunda o nível ao desrespeitar a autonomia e a institucionalidade que para o estudioso ainda se manteriam.

\section{FUTURO CONTROLADO}

A Educação tem a característica de direito humano fundamental anterior ao fato de ser bem público, entretanto os Direitos Humanos não possuem eficácia erga omnes no Direito Internacional e seu reconhecimento jurídico nacional é devido à noção de direitos fundamentais, como conceitua Fábio Konder Comparato:

São os direitos que, consagrados na Constituição, representam as bases éticas do sistema jurídico nacional, ainda que não possam ser reconhecidos, pela consciência jurídica universal, como exigências indispensáveis de preservação da dignidade humana (COMPARATO, 2013).

Portanto, a Educação por ser direito humano fundamental tem interpretação conforme os dispositivos que disciplinam como direito da sociedade e dever do Estado na Constituição Federal de 1988, na Lei de Diretrizes e Base da Educação Nacional (1996) e no Plano Nacional de Educação em Direitos Humanos (2007, p. 23).

A Constituição Federal, documento base do direito brasileiro, reserva seção específica no texto legal para o assunto e institui o princípio da autonomia da universidade no artigo 207 que está sendo ameaçado de forma constante pelo atual governo do presidente Jair Bolsonaro por ser espírito da universidade pública, in verbis: "As universidades gozam de autonomia 
didático-científica, administrativa e de gestão financeira e patrimonial, e obedecerão ao princípio de indissociabilidade entre ensino, pesquisa e extensão".

O governo federal na figura do atual presidente Jair Bolsonaro e dos incapazes Ministros da Educação estão instaurando o projeto de controle das universidades públicas, principalmente das universidades federais, com desrespeitos que vão desde o corte em verbas por questões ideológicas ao "Programa Institutos e Universidades Inovadoras" - Future-se.

A maioria esmagadora das universidades federais brasileiras recusa e repudia o Future-se, com declarações e análises sobre as consequências do programa para a preservação da universidade e o direito ao acesso.

O programa é o projeto de mercantilização do ensino superior utilizado pelo governo e a evidência, dentre várias, está com a proposta de instauração das "Organizações Sociais" que colocam fim ao sentido de instituição social e desrespeitam diretamente a autonomia universitária, conforme ensina Marilena Chauí:

A instituição social aspira à universalidade. A organização sabe que sua eficácia e seu sucesso dependem de sua particularidade. Isso significa que a instituição tem a sociedade como seu princípio e sua referência normativa e valorativa, enquanto a organização tem apenas a si mesma como referência, num processo de competição com outras que fixaram os mesmos objetivos particulares. Em outras palavras, a instituição se percebe inserida na divisão social e política e busca definir uma universalidade (imaginária ou desejável) que Ihe permita responder às contradições, impostas pela divisão. Ao contrário, a organização pretende gerir seu espaço e tempo particulares aceitando como dado bruto sua inserção num dos polos da divisão social, e seu alvo não é responder às contradições, e sim vencer a competição com seus supostos iguais (CHAUÍ, 2003).

Além do ensinamento da Educadora, as universidades federais se atentam ao fato da Organização Social, como podem constatar na declaração do Ceará (IFES, 2019) e na nota do Rio Janeiro (IFES, 2017) das IFES de ensino superior, ferir diretamente a essência da universidade de forma inconstitucional, antidemocrática, antirrepublicana e anti-direitos humanos.

O professor e ex-reitor da Universidade Federal do Rio de Janeiro (UFRJ) Roberto Leher analisou o programa coercitivo e arbitrário e listou as principais características do Projeto de Lei (LEHER, 2019).

O Future-se não é um programa, mas um projeto com propostas sem informações suficientes no curto, médio e longo prazos que definem seus benefícios. As únicas verdades são: a intensificação da mercantilização das universidades públicas federais, o controle das autonomias institucional, intelectual e financeira por parte do Estado e o desrespeito ao direito fundamental da Educação ao modificar dezessete leis de forma arbitrária entre elas a LDB.

A frase atemporal do Educador Darcy Ribeiro proferida em 1977 (SO ESCOLA, 2018): "A crise da Educação no Brasil não é uma crise, é um projeto", representa veemente a intenção do governo fascista (ECO, 2019), 
autoritário (ECO, 2019) e opressor (CARTA CAPITAL, 2019) que está em curso no país.

De acordo com Canoy (1985), o poder advém do sistema político e assim o sistema educacional será sempre baseado na teoria específica imposta pelo governo em exercício e no caso brasileiro atual tem como objetivos a exclusão social e o controle estatal.

O fenômeno do controle social impositivo arbitrário, estudado pelo autor principal, é a forma utilizada pelos governantes autocratas para instaurem seus projetos de dominação na falta de compromissos com os ideais democráticos e princípios humanos dotados de ilegalidades, injustiças, imoralidades e exclusão.

O Estado de bem-estar social é atrofiado para o Estado de interesses comerciais e o processo de transformação é executado quando controlam o pensar e o saber da população em uma comunidade.

A qualidade da universidade pública é comprovada nos índices de avaliação e chega atingir aproximadamente $80 \%$ de notas superiores a 3,0 (média), enquanto as universidades privadas diversificam o ensino com a modalidade EAD que atenua a situação de baixa qualidade pela inexistência de ensino, pesquisa e extensão como grupo integrado e afasta completamente a necessidade de estágios e produções acadêmicas para a conclusão do curso (LOPES; VALLINA, 2017).

No EAD, encontramos um primeiro e sério problema: os discentes não tem supervisão direta acadêmica, pois não se encontram presencialmente com o professor responsável pelo processo de supervisão acadêmica. A supervisão ocorre de forma virtual, mediada pelo tutor, cuja formação é limitada, isto é, dos tutores não são exigidas qualificações mínimas, como o mestrado, e não há nem mesmo transparência e publicização do seu perfil de tais tutores. [...] qualquer docente pesquisador tem a plena clareza de que realizar a pesquisa exige condições de trabalho docente efetivas, o que envolve carga horária para tal e dedicação do docente a um pequeno número de alunos no processo de Iniciação Científica. Como fazer isso, na modalidade de EAD, se o contato com os docentes mais qualificados (e não com os tutores, que não são contratados nem como docentes), produtores do material pedagógico e das aulas virtuais, ocorre virtualmente? Como formar pequenos grupos de I.C., nessas condições de trabalho e com uma modalidade de ensino que, por sua natureza e dinâmica, não se propõe a isso? (PEREIRA, 2013).

O ensino superior brasileiro gratuito e de qualidade ao se transformar em universidade mercantil, pela falta de investimentos no setor público e a mercantilização da Educação como setor de serviços, se distancia da boa formação e qualificação dos estudantes.

A exclusão social caminha por todos os níveis da Educação como construção que termina com a universidade pública, com apenas $25 \%$ das matrículas do ensino superior, de comprovada boa qualidade concentra as classes sociais mais ricas.

A baixa qualidade do ensino público nos graus fundamental e médio tem encaminhado os filhos das classes mais ricas para as escolas privadas e, com o preparo que ali recebem, são eles que irão concorrer em melhores condições às universidades públicas, cujo nível e cuja qualidade são superiores aos das universidades privadas. Dessa maneira, a educação superior pública tem sido conivente com 


\begin{abstract}
a enorme exclusão social e cultural dos filhos das classes populares que não têm condições de passar da escola pública de ensino médio para a universidade pública. Portanto, somente a reforma da escola pública de ensino fundamental e médio pode assegurar a qualidade e a democratização da universidade pública. A universidade pública deixará de ser um bolsão de exclusões sociais e culturais quando o acesso a ela estiver assegurado pela qualidade e pelo nível dos outros graus do ensino público (CHAUÍ, 2003).
\end{abstract}

A entrada exponencial das classes populares nas universidades criou a impressão de conquista da luta social pelo direito à educação através da democratização do acesso ao ensino superior (SANTOS, 2011).

Contudo, a entrada aconteceu de forma esmagadora nas universidades privadas, com 0 auxílio primordial dos programas de financiamento estudantil como FIES e ProUni, que é notório e exaustivo nessa pesquisa a baixa qualidade do ensino ofertado nesses estabelecimentos educacionais comerciais que objetivam apenas o lucro e não a formação científica.

O problema se encontra na falsa percepção de que entrar na universidade, em si, é garantia de mudança social e evolução profissional, entretanto o desemprego no Brasil comprova o erro tendo profissionais com graduações e até mesmo pós-graduações não inseridos no mercado de trabalho.

\title{
4. CONSIDERAÇÕES FINAIS
}

A redefinição da Educação como mercadoria através do processo de mercantilização nacional e inserção como setor de serviços na Organização Mundial do Comércio tem como objetivo transformar o conhecimento crítico que deve libertar e conscientizar em aparato de dispersão social.

O Estado ao se afastar de sua responsabilidade constitucional de investir no setor universitário público para expandir e consolidar as universidades mercantis demonstra a intenção de beneficiar o capital ao controlar a evolução social e mental da população.

As universidades mercantis não possibilitam aos estudantes a formação e qualificação necessárias ao mercado de trabalho e a vida porque estão focadas exclusivamente no dinheiro e endividamento das classes populares que na busca por empregos percebem a discriminação entre os diplomas do setor público e privado.

As universidades privadas permitiram parcialmente a democratização e inclusão no ensino superior, haja vista o crescimento exponencial de graduações nas classes populares, entretanto a baixa 
qualidade do ensino revela a problemática do desvio completo de investimentos.

A universidade pública deve caminhar para a inclusão e distanciamento de seu elitismo para que possibilite a formação de qualidade sem distinção de classes e para isso necessita de financiamento público para aumentar o número de reservas de vagas que é o único caminho, no momento devido à problemática do ensino fundamental e médio, para a democratização e inclusão, de fato, das universidades.

O controle social impositivo arbitrário trabalha para que a dispersão da realidade social induza as pessoas a acreditarem que 0 investimento em programas estatais tem impacto apenas positivo para o ensino superior democrático, inclusivo, livre e crítico, mas na verdade se pretende investir no setor privado para que as universidades mercantis continuem lucrando e expandindo seus negócios em beneficio do projeto de ignorância que é imoral perante o bem estar-social, injusto pelo desequilíbrio de investimentos, ilegal devido às circunstâncias necessárias para se atingir como o Future-se e principalmente excludente em toda a sua complexidade.

A exclusão social acontece pela concentração das classes mais ricas nas universidades públicas que possuem altas taxas de avaliações positivas e objetivo principal das pessoas que buscam o conhecimento em contraposição a concentração das classes populares nas universidades privadas mercantis que não possuem se quer projetos prático-pedagógicos.

A mercantilização intensifica o elitismo e afasta o acesso das classes populares no setor público que pelo controle estatal faz com que 0 conhecimento se perpetue na classe dominante.

O Estado não pode escolher apenas um setor para investimento, haja vista caminharem juntos para o desenvolvimento educacional do país e por isso deve investir nos programas estudantis das universidades privadas e das universidades públicas.

A Reforma Universitária é indispensável para o atual estágio da Educação no Brasil e deve ser dotada de autonomia financeira, intelectual e institucional para que as universidades possam exercer a função como instituição social que trabalha com e para a sociedade.

Os programas, projetos e propostas com intuito de sufocar as universidades públicas ao bel-prazer do comércio buscam a disseminação de discriminações e não são os caminhos para a reforma necessária.

A Educação deve ser totalmente pública para que na mesma sala de aula esteja o proletariado e a burguesia, crítica para que consiga perceber as diferenças sociais como seres fardados a viverem falsas vidas como filhas e 
filhos do capitalismo, livre para que possa reivindicar as mudanças necessárias, democrática para que haja autoafirmação dos estudantes e engajamento com a sociedade e principalmente inclusiva para que seja Educação.

\section{REFERÊNCIAS}

ANDRADE, Bruna Cataldo de. A Mercantilização do Ensino Superior no Brasil desde 2000: uma Análise do Avanço do FIES e PROUNI. Disponível em: https://sep.org.br/anais/Trabalhos\%20para\%200\%20site/Area\%205/67.pdf. Acesso em: 30 ago. 2019

BRASIL. Constituição da República Federativa do Brasil de 1988. Diário Oficial da União. Poder Legislativo, Brasília, DF, 5 out. 1988. Disponível em: http://www.planalto.gov.br/ccivil_03/constituicao/constituicaocompilado.htm. Acesso em: 30 de ago. 2019.

. Plano Nacional de Educação em Direitos Humanos. Brasília: Secretaria Especial dos Direitos Humanos, 2007.

Lei no 9.394, de 20 de dezembro de 1996. Estabelece as diretrizes e bases da educação nacional. Diário Oficial da União. Poder Legislativo, Brasília, DF, 20 dez. 1996. Disponível em:

http://www.planalto.gov.br/ccivil 03/LEIS/L9394.htm. Acesso em: 30 ago. 2019

BORGES, Maria Creusa de Araújo. A educação superior numa perspectiva comercial: a visão da Organização Mundial do Comércio. Disponível em: https://seer.ufrgs.br/rbpae/article/view/19328/11228. Acesso em 30 ago. 2019

BRUNNER, José Joaquin; URIBE, Daniel. Mercados universitários: el Nuevo scenario de la educación superior. Santiago: Ediciones Universidad Diego Portales, 2007.

CALDERÓN, Adolfo Ignácio. Universidades Mercantis: a institucionalização do mercado universitário em questão. Perspec. v.14 n.1. São Paulo, Jan./Mar, 2000.

CARTA CAPITAL. Jair Bolsonaro perpetua opressões com sua retórica destrutiva. Disponível em: https://www.cartacapital.com.br/opiniao/jairbolsonaro-perpetua-opressoes-com-sua-retorica-destrutiva/. Acesso em: 30 ago. 2019. 
CASTELLS, Manuel. The university system: engine of development in the new world economy. In: SALMI, Jamil; VERSPOOR, Adriaan M. Revitalizing higher education. Oxford: IAU, 1994.

CEFET/RJ et al. Nota das Instituições Federais de Ensino Superior do Estado do Rio de Janeiro. Disponível em: https://ufrj.br/sites/default/files/imgnoticia/2019/07/ notaconjuntaifesri.pdf. Acesso em: 30 ago. 2019.

CHAUÍ, Marilena. A universidade pública sob nova perspectiva. 24. ed. Rio de Janeiro: Revista Brasileira de Educação, 2003.

COMISSÃO DO CONSELHO DE CULTURA E EXTENSÃO DA UNIVERSIDADE DE SÃO PAULO. Relatório sobre a inclusão do ensino como item dos setores de serviços, no Acordo Geral sobre o Comércio de Serviços negociado no âmbito da Organização Mundial do Comércio. São Paulo: 2003

COMPARATO, Fábio Konder. A afirmação Histórica dos Direitos Humanos. 3 ed. São Paulo: Saraiva, 2003.

ECO, Umberto. O fascismo eterno. Tradução Eliana Aguiar. 2. ed. Rio de Janeiro: Record, 2019.

FASUBRA. Lei de Diretrizes e Bases da Educação Nacional. Tese de Universidade. Rio de Janeiro: FASUBRA, 1988.

FOLHA DE SÃO PAULO. Bolsonaro ameaça a democracia brasileira.

Disponível em https://www1.folha.uol.com.br/colunas/stevenlevitsky/2018/08/bolsonaro-ameaca-a-democracia-brasileira.shtml. Acesso em: 30 ago. 2019

FREIRE, PAULO. Pedagogia do oprimido. 68. ed. Rio de Janeiro/São Paulo: Paz e Terra, 2019.

INEP. Evolução do Ensino Superior 1980-1996. Brasília: MEC, 1998.

LAVINAS, L. The Takeover of Social Policy by Financialization. 1. ed. New York: Springer 19 Nature, 2017.

LEHER, Roberto. Análise Preliminar do "Future-se" indica a refuncionalização das universidades e institutos federais. Disponível em: https://avaliacaoeducacional.files.wordpress.com/2019/07/sobre-o-future-senotas-prelim-rleher-24-07pdf.pdf. Acesso em: 30 ago. 2019.

LOPES, Maria Gracileide Alberto; VALLINA, Kátia. A MERCANTILIZAÇÃO DO ENSINO SUPERIOR NO CONTEXTO ATUAL: considerações para o debate. Disponível em:

http://www.joinpp.ufma.br/jornadas/joinpp2017/pdfs/eixo13/amercantilizacaodoe 
nsinosuperiornocontextoatualconsideracoesparaodebate.pdf. Acesso em: 30 ago. 2019

LEVITSKY, Steven; ZIBLATT, Daniel. Como as democracias morrem. Tradução Renato Aguiar. 1. ed. Rio de Janeiro: Zahar, 2018.

MOTTA, Elias de Oliveira. Direito Educacional e educação no século XXI: com comentários à nova Lei de Diretrizes e Bases da Educação Nacional. Brasília: UNESCO, 1997.

PEREIRA, Dahmer Larissa. Expansão dos cursos de Serviço Social na modalidade EAD no Brasil: análise da tendência à desqualificação profissional. In: PEREIRA, Larissa; ALMEIDA, Ney Luiz Teixeira (orgs). Coletânea Nova de Serviço Social. Rio de Janeiro: Lumen Juris, 2013.

RIBEIRO, Gustavo Ferreira. Afinal, o que a organização mundial do comércio tem a ver com a educação superior? Disponível em:

http://www.scielo.br/pdf/rbpi/v49n2/a08v49n2.pdf. Acesso em: 30 ago. 2019

HERINGER, Rosana (Org.). Democratização da Educação Superior no Brasil Novas Dinâmicas, dilemas e aprendizados. Disponível em: http://flacso.org.br/files/2016/06/caderno gea n7 digitalfinal.pdf. Acesso em: 30 ago. 2019

Sistema Integrado de Administração Financeira (SIAFI). SIGA BRASIL painel cidadão. Disponível em:

http://www9.senado.gov.br/QvAJAXZfc/opendoc.htm?document=senado\%2Fsi gabrasilpainelcidadao.qvw\&host=QVS\%40www9\&anonymous=true\&Sheet=sh OrcamentoVisaoGeral. Acesso em: 30 ago. 2019

SAMPAIO, Helena; KLEIN, Lúcia. Políticas de ensino superior na América Latina: uma análise comparada. In: Revista Brasileira de Ciências Sociais, n.24, 1994.

. Ensino superior no Brasil - O setor privado. São Paulo:

$\overline{\text { Fapesp/Hucitec, } 2000 .}$

SANTOS, Boaventura de Sousa. A universidade no século XXI: para uma reforma democrática e emancipatória da universidade. 3 ed. São Paulo: Cortez, 2011.

A globalização e as ciências sociais. São Paulo: Cortez, 2002.

SÓ ESCOLA. Educação no Brasil: Darcy Ribeiro e a crise da educação. Disponível em:https://www.soescola.com/2018/07/educacao-no-brasil.html. Acesso em: 30 ago. 2019.

UNIVERSIDADE FEDERAL DO CEARÁ. Declaração dos reitores das instituições federais de ensino superior no Ceará. Disponível em: 
http://www.ufc.br/noticias/13424-declaracao-dos-reitores-das-instituicoesfederais-de-ensino-superior-no-ceara. Acesso em: 30 ago. 2019 


\title{
ATENDIMENTO EM INSTITUIÇÕES CONVENIADAS DE EDUCAÇÃO INFANTIL: O que apontam as pesquisas na área?
}

\author{
MALTA, Leticia Pereira \\ Pesquisadora - UNESP/Franca \\ SOUZA, Tatiana Noronha de \\ Pesquisadora - Universidade Estadual Paulista - UNESP/Franca. \\ E-mail para contato: leticiamalta7@hotmail.com
}

\section{INTRODUÇÃO}

Ao analisar a trajetória da educação infantil, nota-se que ela sempre foi marcada pelo caráter assistencialista. No Brasil, até o final da década de 1980, a educação infantil se pautava nessa perspectiva, que tinha como finalidade amparar crianças pobres, vítimas do abandono e da negligência de seus responsáveis. $O$ atendimento a elas, na maioria das vezes, era feito por entidades filantrópicas e assistenciais. Nessas associações, as crianças pequenas eram vistas apenas como seres desprovidos de cuidados e não como sujeitos de direitos, pensantes e passíveis de uma educação formal.

A Constituição de 1988 (Brasil, 1988), inclui a educação infantil no sistema educativo e delega aos municípios a responsabilidade, prioritariamente, do atendimento a demanda desta etapa. Posteriormente, o Estatuto da Criança e do Adolescente - ECA (Brasil, 1990), reforça os dispositivos constitucionais sobre a educação de zero a seis anos, e contribuindo para o crescimento de creches mantidas pelo poder público.

A partir da LDB (Brasil, 1996), a educação infantil passou a integrar a primeira etapa da Educação Básica e isso contribuiu para superar o caráter assistencialista predominante, através do reconhecimento das necessidades educacionais específicas das crianças à faixa etária de 0 a 6 anos. Com o aumento da participação das mulheres no mercado de trabalho e as modificações na organização e estrutura familiar, somados ao aparato legal conquistado, é inegável que, nas últimas décadas, houve um significativo aumento da procura por vagas na Educação Infantil. O poder público, alega não conseguir atender toda a demanda, e vem optando por firmar convênios junto a entidades filantrópicas, confessionais e comunitárias com o objetivo de buscar uma solução para o problema da falta de vagas.

Os convênios são regulamentados pela lei 8.666/93 (BRASIL, 1993) e nela se estabelece que cabe à administração pública o papel de fiscalizador da qualidade do serviço que o conveniado presta. De acordo com 
Di Pietro (2008, p. 319), o convênio é uma "[...] forma de ajuste entre o poder público e entidades públicas ou privadas para a realização de objetivos de interesse comum, mediante mútua colaboração. A LDB deixa claro que, tanto a autorização, como a supervisão das instituições de educação infantil ficam a cargo das secretarias municipais de educação. Ao Conselho Municipal de Educação, cabe a definição de normas para o funcionamento dessas instituições com base em referenciais nacionais.

Contudo, especialistas alegam que creches conveniadas praticam um atendimento de menor qualidade. Entre os anos de 1983 e 1990, no Estado do Mato Grosso, foram implantados programas de educação infantil com o intuito de ampliar o atendimento. O estudo de Silva (SILVA, 1999) demonstra que esse atendimento foi feito através de convênios federais com entidades e municípios visando baixo custo. Identificava-se nessas entidades, espaços adaptados e pessoal não qualificado. Rosemberg (2001) salienta em seu estudo que organismos internacionais como o Banco Mundial, a Unesco e a Unicef, considera a falta de vagas na educação infantil uma situação de emergência e acredita que a solução seria a ampliação de vagas a baixo custo para o Estado. Füllgraf (2002) aponta, em seu estudo sobre processo de crescimento do atendimento da Educação Infantil em Florianópolis no período de 25 anos, o crescente recurso ao uso dos convênios como meio de expandir as matrículas, diminuindo gastos.

Nesse contexto de baixa qualidade do atendimento nas instituições conveniadas de educação infantil, revelado através das precárias condições dos prédios e equipamentos, falta de materiais pedagógicos, baixa escolaridade dos educadores, ausência de projetos pedagógicos e dificuldades de comunicação com as famílias, observa-se um deslocamento da preocupação com a democratização do acesso para a ênfase na condição de funcionamento nessas instituições.

O Ministério da Educação oferece publicações que apontam diretrizes para a construção de uma regulamentação e melhoria da qualidade do atendimento na educação infantil. Pode-se destacar os seguintes documentos: Referencial Curricular Nacional para a Educação Infantil (BRASIL, 1998a); Subsídios para Credenciamento e Funcionamento de Instituições de Educação Infantil (BRASIL, 1998b); Diretrizes Curriculares Nacionais para a Educação Infantil, Resolução CEB № 1, de 7 de abril de 1999 (BRASIL, 1999); Critérios para um Atendimento em Creches que Respeite os Direitos Fundamentais da Criança (Campos; Rosemberg, 2009); Indicadores da Qualidade na Educação Infantil (BRASIL, 2009); Parâmetros Básicos da Infraestrutura para Instituições de Educação Infantil (BRASIL, 2006).

$\mathrm{Na}$ direção de promover qualidade do atendimento infantil, as escalas de avaliação permitem uma apuração minuciosa dos ambientes 
infantis. A Early Childhood Environment Rating Scale - ECERS (Harms; Clifford, 1980 apud Oliveira; Furtado; Souza; Campos-de-Carvalho, 2003) é uma escala estadunidense, desenvolvida para avaliar a qualidade do atendimento oferecido em instituições educacionais voltados para o público de 0 a 6 anos de idade. Em "[...] seus 37 itens são organizados em sete subescalas: Cuidados Pessoais, Materiais e Mobiliário para as Crianças, Experiências de Linguagem e Raciocínio, Atividades de Motricidade Global e Fina, Atividades Criativas, Desenvolvimento Social e Necessidades do Adulto" (Oliveira; Furtado; Souza; Campos-de-Carvalho, 2003 p. 43). A partir da ECERS foi desenvolvida a Infant/ Toddler Environment Rating Scale -ITERS (Harms; Cryer; Clifford, 1990 apud Oliveira; Furtado; Souza; Campos-deCarvalho, 2003), que é um instrumento exclusivo para avaliar ambientes grupais para crianças de até 30 meses de idade e "[...] seus 35 itens são agrupados em sete subescalas: Material e Mobiliário, Rotinas e Cuidados Pessoais, Linguagem Oral e Compreensão, Atividades de Aprendizagem, Interação, Estrutura do Programa e Necessidades do Adulto. " (Oliveira; Furtado; Souza; Campos-de-Carvalho, 2003 p. 43).

Considerando a ausência de instrumentos brasileiros para avaliação da qualidade dos ambientes em instituições coletivas de crianças de 0 a 6 anos, especialistas como Furtado e Campos-de-Carvalho (Oliveira; Furtado; Souza; Campos-de-Carvalho, 2003), utilizam a ITERS e ECERS com o objetivo de avaliar a qualidade do ambiente oferecido em instituições educacionais infantis mediante sua adequação, precisão e validação em nosso contexto sociocultural.

Assim, o presente artigo tem como objetivo geral apresentar uma análise inicial de publicações realizadas sobre a qualidade do atendimento nas instituições conveniadas de educação infantil, como parte de uma pesquisa de mestrado. Tem como justificativa a importância de se pensar na naturalização do processo de privatização do atendimento infantil, que tem apresentado baixos níveis de qualidade em razão da pouca supervisão estatal.

\section{METODOLOGIA}

A partir da metodologia de pesquisa bibliográfica foi realizado um levantamento de artigos que tratam da qualidade do atendimento nas instituições conveniadas de educação infantil. No google acadêmico foram cruzadas três palavras-chave, para realização da busca: creche, conveniada e qualidade. 
Através do cruzamento, resultaram os seguintes artigos: Campos, Füllgraf e Wiggers (2006), Ribeiro (2013), Rosemberg (1996), Nascimento e Silva (2015) e Susin e Peroni (2011). Foi realizada a leitura individual de cada artigo, e a tabulação das informações inseridas em uma planilha de Excel, contendo informações para análise do material: Qual o objetivo do estudo? Qual foi a metodologia utilizada? Quais foram os resultados encontrados? $O$ que os resultados dizem sobre a qualidade do atendimento nas instituições conveniadas de educação infantil? A partir desses resultados foram feitas considerações à luz da literatura que fundamenta o presente estudo.

\section{RESULTADOS E DISCUSSÃO}

Após a tabulação das publicações, identifica-se que dois artigos foram publicados na revista Cadernos de Pesquisa - Fundação Carlos Chagas - (CAMPOS, FÜLLGRAF, WIGGERS, 2006; ROSEMBERG, 1996); um publicado na Revista de Educação PUC-Camp (RIBEIRO, 2013); um publicado na Revista de Financiamento da Educação (NASCIMENTO, SILVA, 2015); e um publicado na Revista Brasileira de Política e Administração da Educação (SUSIN, PERONI, 2011). Os materiais constam de uma pesquisa documental (NASCIMENTO, SILVA, 2015), uma pesquisa de campo (SUSIN, PERONI, 2011), uma autoavaliação (RIBEIRO, 2013), tabulações e revisão bibliográfica (ROSEMBERG, 1996) e um levantamento sobre resultados de pesquisas empíricas (CAMPOS, FÜLLGRAF, WIGGERS, 2006).

O artigo de Nascimento e Silva (2015) teve como objetivo fazer uma análise da política de convênios firmados pela Prefeitura de São Paulo para atender a demanda da educação infantil. A metodologia consistiu de uma pesquisa nos documentos da prefeitura e no diário oficial, no que tange a temática da realização dos convênios; além disso, foram observadas várias folhas de pagamento de docentes, com o propósito de verificar a remuneração dos mesmos. Os resultados apontam que creches conveniadas chegam a possuir um investimento $40 \%$ menor que creches de administração direta e, parte dessa economia decorre do fato de que docentes de creches conveniadas recebem salários menores. Dados destacam que os "docentes integrantes da rede municipal de ensino direta, possuíam um piso salarial de $\mathrm{R} \$ 3.000,00$ para trabalharem 30 horas semanais, enquanto os docentes que trabalhavam nas creches conveniadas tinham como piso salarial o valor de $R \$$ 1.846,07 para trabalharem 40 horas semanais" (NASCIMENTO, SILVA, 2015 p.10). 
O estudo de Susin e Peroni (2011) objetivou analisar o funcionamento de creches que firmaram convênios com a prefeitura de Porto Alegre. Realizaram uma pesquisa de campo por meio de questionários distribuídos em 133 creches conveniadas, observações in loco em quatro creches e entrevistas com profissionais da educação e lideranças comunitárias. Esse estudo indica que existe uma tensão entre a Secretaria de Educação de Porto Alegre e as direções das creches conveniadas. Termos como o controle do orçamento, investimentos em infraestrutura e qualidade pedagógica só foram possíveis ser estabelecidos, mediante um contrato do convênio. Entretanto, "isto não se efetiva, pois em $27 \%$ das instituições a comunidade não é chamada a fiscalizar e não participa efetivamente do processo de gestão dos recursos das creches. " (SUSIN, PERONI, 2011 p.194).

Outro ponto que esse artigo coloca para apreciação é que para viabilizar a saúde financeira dessas instituições de ensino, é feito por parte delas a cobrança de mensalidades. As próprias autoras questionam que se 0 objetivo das creches conveniadas comunitárias "[...] era atender às populações de baixa renda e, se o valor da mensalidade hoje cobrada está impedindo o cumprimento deste objetivo, o perfil do convênio está mudando, e a condição primeira para a sua existência - atendimento das populações de baixa renda está se perdendo. " (SUSIN, PERONI, 2011 p. 196).

O trabalho de Ribeiro (2013) buscou " verificar quais elementos atuam como facilitadores e/ou dificultadores do processo autoavaliativo; apontar as semelhanças e/ou diferenças constatadas no processo de autoavaliação entre quatro creches; averiguar o potencial e as possíveis limitações do documento utilizado para induzir melhorias na qualidade das creches pertencentes ao universo em questão." (RIBEIRO, 2013 p.66). A metodologia utilizada foi por meio de: roteiro de observação; quadros-síntese dos Indicadores da Qualidade na Educação Infantil (BRASIL, 2009); caderno de campo e registro fotográfico.

Para avaliar a tipologia de poder dentro de uma instituição educacional, utiliza-se a proposta de Formosinho (FORMOSINHO, 1980 apud RIBEIRO, 2013) composta pelas seguintes categorias: "[..] poder normativo sustenta-se através da recorrência a normas objetivas e/ou subjetivas"(RIBEIRO, 2013 p.69); "[...] poder cognoscitivo é o saber profissional ou de especialista, baseado nos conhecimentos científicos, técnicos e/ou tecnológicos"(RIBEIRO, 2013 p.69); poder pessoal está associado a características de liderança e poder de persuasão que alguns indivíduos manifestam em determinados ambientes, independente do grau hierárquico; "[...]poder autoritativo é baseado no poder formal, institucional, ou seja, ele está atrelado ao cargo, à posição hierárquica do indivíduo em uma organização" 
(RIBEIRO, 2013 p.70). O resultado das autoavaliações sobre as relações de poder no cotidiano das creches constatou que diretoras, coordenadoras e professoras têm os poderes normativo, cognoscitivo, pessoal e autoritativo. Já auxiliares de enfermagem, cozinheiras/auxiliares de cozinha e pais apenas possuem o poder pessoal. As atendentes gerais mostraram não desenvolver qualquer tipo de poder no cotidiano. Em relação as assembleias de autoavaliação, as diretoras, coordenadoras e professoras tiveram avaliação ativa; as auxiliares de enfermagem, cozinheiras/auxiliares de cozinha e pais, reservada, e as atendentes gerais, passiva.

Já Rosemberg (1996) teve como objetivo entender o viés de gênero que tem marcado a concepção e a pratica de educação infantil no Brasil e a dinâmica das relações raciais. Este estudo teve como base metodológica tabulações especiais das PNADs (Pesquisas Nacionais sob Amostra Domiciliar), tabulações fornecidas pelo IBGE e revisão bibliográfica de trabalhos de Maria Jesus Izquierdo e Barbara Beatty. Certificou-se que a desqualificação da educação infantil e decorrente da sua vinculação à esfera da vida reprodutiva baseada em amor as crianças e técnicas educacionais explicitamente associadas a tipos de comportamentos femininos.

$O$ artigo também nos mostra que a profunda segregação social se mantém na utilização dos equipamentos sociais e esses são usados pelos desfavorecidos economicamente. Nota-se que "[...] quanto mais pobre, mais cedo e mais tempo a criança frequenta os equipamentos de educação infantil e que são, justamente, os de pior qualidade" (ROSEMBERG, 1996 p. 64). Percebe-se que a expansão desordenada da educação infantil, através das trajetórias paralelas (creches públicas, creches conveniadas e pré-escolas públicas e conveniadas) oferece à população um serviço simultâneo com qualidade excessivamente desigual. É essa desigualdade no custeio/qualidade que apena crianças oriundas de famílias de baixa renda e negras de diferentes formas (ROSEMBERG, 1996).

Por fim, a publicação de Campos, Füllgraf e Wiggers (2006) analisou os dados obtidos por meio de levantamento sobre resultados de pesquisas empíricas acerca da qualidade da educação infantil brasileira, divulgados entre 1996 e 2003. Para realização do artigo recorreram a revisão de estudos publicados na Reunião Anual da Associação Nacional de PósGraduação e Pesquisa e Educação - ANPEd -, no Grupo Trabalho Educação da Criança de Zero a seis anos. Os materiais foram selecionados a partir de perspectivas relacionadas à qualidade da educação infantil como: condições de funcionamento; práticas educativas; formação dos professores; propostas pedagógicas e relação com as famílias.

Segundo as autoras, velhas concepções, preconceitos oriundos de uma história de colonização e escravidão, rotinas e práticas herdadas de 
tradições assistencialistas ainda caracterizam o presente das creches e préescolas, além disso, persistem os modelos de atendimento resistentes à introdução das mudanças definidas na nova legislação.

Referente à formação de professores, há uma consciência de que a proposta presente no curso de pedagogia, não atende às necessidades específicas para a laboração em creches e pré-escolas.

Os resultados indicaram que "[...] as creches aparecem em situação mais precária, seja quanto à formação do pessoal, seja quanto à infraestrutura material, adotando rotinas rígidas baseadas quase exclusivamente em ações voltadas para a alimentação, higiene e contenção das crianças" CAMPOS, FÜLLGRAF, WIGGERS, 2006 p.117). Já nas préescolas são vistas condições melhores em relação a infraestrutura e formação dos professores. Entretanto, quanto às rotinas, nota-se pouca flexibilidade e foco em atividades conteudistas e de baixa ludicidade. Tanto nas creches como nas pré-escolas "[...] constatam-se grandes bloqueios na comunicação com as famílias, geralmente percebidas de forma negativa e preconceituosa por parte das equipes das escolas e creches" (CAMPOS, FÜLLGRAF, WIGGERS, 2006 p.118).

As pesquisas selecionadas mostram que a política de convênios foi uma saída encontrada por governos afim de buscar atender a demanda da educação infantil a um custo menor aos cofres públicos. A subordinação de crianças pobres e negras se inicia no berçário, onde encontra-se trabalhadoras com menor escolaridade e "[...] crianças que vivenciam uma rotina de espera: a espera do banho, da comida, da troca de fraldas. " (ROSEMBERG, 1996 p. 64).

Por sua vez, as políticas desenvolvidas pelos diferentes níveis governamentais nem sempre respeitam a legislação e ainda não foi equacionada a questão do recurso público para a educação infantil. Além disso, em muitos estados e municípios persiste a "[...] mentalidade de que creches e pré-escolas não necessitam de serviços eficientes de supervisão, não requerem prédios e equipamentos adaptados às necessidades infantis, não precisam de livros nem de brinquedos específicos, nem profissionais qualificados e bem remunerados. " (CAMPOS, FÜLLGRAF, WIGGERS, 2006 p.120).

\section{CONSIDERAÇÕES FINAIS}

Verificamos que os artigos abordam diferentes contextos sobre a educação infantil, e são unânimes ao afirmar creches e pré-escolas 
conveniadas oferecem um serviço de menor qualidade que as de administração direta, levando em consideração aspectos como a formação dos profissionais, os equipamentos, a infraestrutura dos prédios e as rotinas e práticas pedagógicas.

Percebe-se que é escassa a pesquisa acadêmica sobre a temática da qualidade do atendimento nas instituições conveniadas de educação infantil. Nota-se que carece a realização de mais pesquisas principalmente que se concentram no âmbito das creches.

Aspectos da assistência social ainda influenciam a concepção de educação infantil e estão presentes principalmente nas rotinas das creches, por adotarem práticas rígidas embasadas em ações voltadas para a alimentação, higiene e contenção das crianças. Na pré-escola, as rotinas também são caracterizadas como pouco flexíveis e as práticas focalizadas em atividades de cunho escolar deixando de lado a brincadeira e o lúdico.

Outro aspecto que merece reflexão é o desenvolvimento das autoavaliações nas instituições de educação infantil. Percebe-se que a severa hierarquia criada no cotidiano faz que as mesmas percam a qualidade de diagnóstico sobre os problemas, pois há uma sobreposição a visão de alguns segmentos em relação aos outros. Se o ambiente fosse mais democrático nas creches e pré-escolas em que existem autoavaliações, certamente 0 andamento das atividades seria mais exitoso.

Assim, para reverter a situação nas instituições conveniadas, se faz importante a qualificação e valorização do trabalho docente e dos profissionais que lidam diretamente com as crianças, além de melhorias nos prédios e no fornecimento de materiais e equipamentos. Para que isso seja possível, é necessário que as prefeituras invistam mais recursos financeiros a essas entidades e supervisionem como estão sendo administrados esses repasses.

Sobre a infraestrutura e os materiais, deve-se ressaltar não só a importância da aquisição, mas também do investimento em orientações operacionalizadas às secretarias de educação e entidades, a respeito do uso desses equipamentos e também relativas às novas construções e reformas realizadas nos prédios utilizados por creches e pré-escolas.

É necessário que os representantes da administração pública e das instituições conveniadas mantenham o diálogo em um clima de colaboração mútua. $O$ que se identifica através dos estudos são vários embates entre as partes, dificultando o aprimoramento da política de educação infantil de forma integrada.

Apesar da luta dos movimentos sociais pela ampliação do acesso e melhoria de qualidade, observa-se uma precarização dos serviços com a 
implantação de projetos de baixo custo, reforçados pelos relatórios de agências internacionais como Banco Mundial, estes reforçam a desigualdade social no país e desconsideram o conhecimento acumulado pelas pesquisas sobre a educação na primeira infância.

\section{REFERÊNCIAS}

BRASIL. Constituição da República Federal do Brasil. Disponível em: <http://www.planalto.gov.br/ccivil_03/constituicao/constituicao.htm> Acesso em: 27 de julho de 2019.

BRASIL. Diretrizes Curriculares Nacionais para a Educação Infantil. CEB Câmara de Educação Básica do Conselho Nacional de Educação. Resolução № 1. Brasília, 1999.

BRASIL. Estatuto da Criança e do Adolescente. Disponível em: <http://www.planalto.gov.br/ccivil_03/leis//8069.htm> Acesso em: 27 de julho de 2019.

BRASIL. Indicadores da Qualidade na Educação Infantil. Brasília: MEC/SEB, 2009

BRASIL. Lei n`9394, de 20 de dezembro de 1996. Estabelece as diretrizes e bases da educação nacional. Disponível em: <http://www.planalto.gov.br/ccivil_03/leis/l9394.htm> Acesso em 27 de julho de 2019.

BRASIL, Lei 8.666, de 21 de junho de 1993. Regulamenta o art. 37, inciso XXI, da Constituição Federal, institui normas para licitações e contratos da Administração Pública e dá outras providências. Disponível em: <http://www.planalto.gov.br/ccivil_03/leis//8666cons.htm> Acesso em 27 de julho de 2019.

BRASIL. Parâmetros Básicos da Infraestrutura para Instituições de Educação Infantil Brasília: MEC/SEB, 2006.

BRASIL. Referencial Curricular Nacional para a Educação Infantil. Brasília: Secretaria de Educação Fundamental, 1998a. 
BRASIL. Subsídios para Regulamentação e Credenciamento das Instituições Infantis. Vol. I. Brasília: Secretaria de Educação Fundamental, 1998b.

CAMPOS, M. M.; FÜLLGRAF, J. B. G.; WIGGERS, V. A qualidade da educação infantil brasileira: alguns resultados de pesquisa. Cadernos de Pesquisa (Fundação Carlos Chagas). São Paulo, v. 36, n. 127, p. 87 - 128, jan. /abr. 2006.

CAMPOS, M. M.; ROSEMBERG, F. Critérios para um atendimento em creches que respeite os direitos fundamentais das crianças. $6^{\underline{a}}$ ed. Brasília, MEC, SEB, 2009.

DI PIETRO, Maria Sylvia Zanella. Direito administrativo. 12a edição. São Paulo: Atlas, 2008.

FÜLLGRAF, J. B. G. Direito das crianças à educação infantil: um direito no papel. s. I., 2002. [Trabalho apresentado na 25를 Reunião Anual da ANPEd].

NASCIMENTO, A. P. S; SILVA, C. N. O. As creches conveniadas em São Paulo: quais os reais motivos dessa opção política. FINEDUCA: Revista de financiamento da educação. Porto Alegre, v. 5, n. 10, 2015.

OLIVEIRA, M. A.; FURTADO, R. A.; SOUZA, T. N. \& CAMPOS-DECARVALHO M. I. Avaliação de ambientes educacionais infantis. Paidéia Cadernos de Psicologia e Educação, Ribeirão Preto, v.13 (25), p.41-58, 2003.

RIBEIRO, B. Indicadores da qualidade na educação infantil: potenciais e limites. Revista de Educação PUC-Camp., Campinas, 18(1):65-74, jan. /abr., 2013.

ROSEMBERG, F. Avaliação de programas, indicadores e projetos em educação infantil. Revista Brasileira de Educação, Rio de Janeiro, n. 16, p. 19-26, jan. /abr. 2001.

ROSEMBERG, F. Educação infantil, classe, raça e gênero. Cadernos de Pesquisa (Fundação Carlos Chagas), São Paulo, n.96, p. 58-65, fev. 1996. 
SILVA. A. S. Educação e assistência: direito de uma mesma criança. Proposições, Campinas, v. 10, n. I, p. 40-53, mar. 1999.

SOUZA, T. N. \& CAMPOS-DE-CARVALHO M. I. Qualidade de ambientes de creches: uma escala de avaliação. Psicologia em Estudo, Maringá, v. 10, n. 1, p. 87-96, jan. /abr. 2005.

SUSIN, M. O. K; PERONI, V. M. V. A parceria entre o poder público municipal e as creches comunitárias: a educação infantil em Porto Alegre. Revista Brasileira de Política e Administração da Educação, Porto Alegre. v.27, n.2, p. 185-201, maio/ago. 2011 


\section{CULTURA E COMPORTAMENTO DE CIDADANIA ORGANIZACIONAL EM AMBIENTES DE ENSINO E APRENDIZAGEM}

ROCHA, Juliano Gomes da Centro Universitário Municipal de Franca - Uni-FACEF julianorochasjb@hotmail.com

SMITH, Marinês Santana Justo Centro Universitário Municipal de Franca - Uni-FACEF marinessmith@facef.br

\section{INTRODUÇÃO}

A gestão nas instituições públicas brasileiras foi inicialmente marcada por modelos burocráticos implantados na década de 1930, por Getúlio Vargas, durante o Estado Novo e depois sofisticados pelo tecnicismo produtivo na década de 70 pelos militares através do Projeto Desenvolvimentista Brasileiro.

Os ideais tayloristas e fordistas que valorizavam vários aspectos fundamentados na estrutura hierárquica, na disciplina rígida, no foco nas metas, nas tarefas repetitivas, na redução do tempo de execução, na produção em série, na análise custo-benefício, no treinamento comportamental, na especialização e por fim na didática mecanicista, contribuíram para que a gestão das instituições públicas se assemelhassem cada vez mais com a gestão praticada nas esferas empresariais.

O sistema educacional, por sua vez, pautado na tendência tecnicista-burocrática atuou nos mesmos moldes do sistema liberal capitalista, promovendo o alinhamento da escola com o sistema produtivo, ao considerar a quantidade de alfabetizados como resultado de uma eficiência produtiva, desconsiderando os aspectos e valores individuais inerentes de cada agente na participação democrática e ativa na construção do conhecimento.

Para tentar alterar esse quadro burocrático, novos procedimentos, na gestão pública, surgem em meados da década de 90 pautados em princípios democráticos com o objetivo de promover um serviço de qualidade frente às necessidades dos cidadãos, tomando novos rumos e conduzindo seus agentes profissionais como o principal recurso capaz de atender a essa demanda. É uma nova forma de olhar sobre tarefa e sobre o servidor, que se dá a partir de uma concepção onde os valores pessoais devam estar alinhados aos valores organizacionais, gerando assim resultados positivos, sem que se estabeleça nenhuma rigidez imposta sobre a realização do mesmo, mas sim diante de um amplo cenário de debate e reflexão. 
Diante deste contexto, o objetivo do trabalho está em compreender os aspectos da cultura que constituem a identificação e a cidadania organizacional em ambientes de ensino e aprendizagem, a fim de subsidiar os conhecimentos necessários para diretrizes que promovam a gestão educacional democrática.

O estudo se caracteriza exploratório. Após a pesquisa bibliográfica acerca dos temas: Cultura, Identidade, Gestão Democrática e Cidadania Organizacional, foi realizada uma análise documental e de observação em uma escola de Ensino Médio e Técnico (ETEC) localizada numa cidade na região de Franca.

\section{CULTURA ORGANIZACIONAL GERANDO IDENTIDADE EM PROCESSO DE GESTÃO DEMOCRÁTICA}

Compreender a cultura de uma organização é um ponto fundamental quando se deseja promover a mudança, pois a mesma somente é efetivada se processada a necessária reconstrução da sua cultura (CROZATTI, 1998).

Na visão da Antropologia a cultura parte do próprio objetivo desta ciência, expresso por Marconi e Presotto (1989) como ciência da humanidade, na qual se preocupa em conhecer cientificamente o ser humano na sua totalidade. Pois a cultura é algo que está presente na vida das pessoas de forma dinâmica, sendo constituída e recriada continuamente a partir de interações sociais, conforme afirma SCHEIN (2009).

Com as empresas não é diferente. Sobre esse ponto Schein (2009) caracteriza a cultura organizacional em três níveis: o primeiro nível acontece nos aspectos que são entendidos como estruturas e processos organizacionais visíveis, os artefatos; o segundo se refere às estratégias, objetivos e filosofias, ou seja, os valores, e por último, o terceiro nível mais profundo, são os fatos que se referem às crenças, percepções e pensamentos, muitas vezes inconscientes, caracterizados como os pressupostos.

A cultura organizacional também pode ser considerada como uma espécie de uma programação mental coletiva que distingue um grupo ou uma categoria de pessoas, de outro grupo ou de outra categoria, como afirmam Kotter e Heskett (2011, apud Cavazote, Moreno Jr. e Turano 2015), e que além disso pode se associar a cultura de uma organização como um elemento crítico nas organizações, pois a mesma tem o poder de influenciar fortemente 0 comportamento de seus membros, assim com as relações que estabelecem uns com os outros, e também na forma de como tomam decisões e definem suas prioridades no trabalho. 
A relação coletiva dos membros de uma empresa quando fortemente arraigada aos seus princípios, faz com que a sua cultura organizacional passa a servir como instrumento de reforço do sistema de valores vigente, diferenciando uma organização de outra qualquer (PIRES E MACEDO, 2006). Como que para Silva e Fadul (2010, p.4) ao relatar sobre cultura enxergam a mesma como um processo reflexivo, pois a qual a cultura organizacional abrange um conjunto de valores que refletem e se refletem em artefatos visíveis, que se alteram em função de fatores internos e/ou externos à própria cultura organizacional.

Fleury (1987, p. 02) define a relação da cultura com outras variáveis e deixa claro sua a influência para o sucesso das organizações.

A cultura deve ser concebida como um conjunto de valores e crenças a ser compartilhados pelos membros de uma organização, deve ser consistente com outras variáveis organizacionais como estrutura, tecnologia, estilo de liderança. Da consistência destes vários fatores depende o sucesso da organização".

No tocante aos valores de uma instituição os mesmos podem ser percebidos pelos indivíduos no contexto organizacional e, ainda serem construídos pela própria organização na medida em que reconhece para si a importância de assumir determinados princípios, favorecendo, junto aos funcionários, a noção de que tais valores fazem parte de sua identidade organizacional. (CAVAZOTE, MORENO JR., TURANO, 2017).

Além do que esses mesmos valores possuem funções relevantes dentro das organizações, inicialmente com a criação de modelos mentais semelhantes entre os empregados, no que tange à missão da organização, evitando assim percepções diferentes, assimilando-os em suas estruturas cognitivas e posteriormente criando uma identidade social, tornando-a única em relação às demais organizações. Nesse aspecto Tamayo (1998) destaca que a percepção desses valores organizacionais pelos empregados estabelece uma imagem da empresa quanto à sua eficiência, tendências à inovação, tipo de gestão, e a interação entre os empregados. As características dessa imagem determinam a identificação do empregado com a empresa e com os seus objetivos

Ao compreender os valores como parte de um processo de um diálogo e de transformação do comportamento social através da aprendizagem, Mendes e Tamayo (1998, p. 2) afirma:

Os valores fazem parte de uma dialética de manutenção e de transformação dos comportamentos humanos pela socialização e aprendizagem permanentes, sendo, por isso, valiosos para as instituições que desejam modelar comportamentos em função de seus interesses. 
Os valores têm o poder de guiar e orientar a vida das organizações, apesar de nem sempre serem explicitados claramente quais as normas e de não terem força imperativa explícita, pois o sistema de valores existente em uma organização forma a pedra fundamental da cultura organizacional, produzindo senso de direção para todos e guia para o comportamento diário dos membros RUSSO (2010).

E ao avaliar de forma compartilhada os valores que expressam ideologias sobre o que seja apropriado para o bom desempenho de uma organização, Tamayo, Mendes e Paz (2000) afirmam ser imprescindível que ocorra seis aspectos fundamentais da vida organizacional, os quais se compreendem em: 1) Autonomia: na qual a importância atribuída à procura de inovação, de criatividade e de independência na execução do trabalho; 2) Conservadorismo: ao dar ênfase na interdependência dos membros da organização e na obtenção de objetivos grupais; 3) Hierarquia: pela relevância dos papéis hierárquicos na estrutura do relacionamento interpessoal, na distribuição de recursos e de poder; 4) Igualitarismo: ao procurar efetivar do bem-estar de todos os membros da organização e a sua participação nos processos decisórios; 5) Domínio: a importância dada ao sucesso organizacional e à satisfação dos clientes e por fim, a 6) Harmonia que representa $\mathrm{o}$ respeito à natureza e à procura de complementariedade organizacional.

Assim a percepção dos valores de uma organização pelos colaboradores, como os comportamentos de comprometimento estão relacionados com a afetividade, com a cidadania organizacional e com a satisfação no trabalho. Pois o comprometimento afetivo pode se definir como um estado em que o indivíduo passa a se identificar com a organização e com os seus objetivos partilhando o desejo de alcançá-los (TAMAYO 1998).

Por meio dessas releituras verifica-se que a compreensão da conduta humana possibilita conceber atitudes de valores, crenças, sentimentos, pensamentos referentes às situações organizacionais, levando 0 colaborador a comprometer-se com as necessidades geradas por tais situações, uma vez que por comprometimento entende-se o ato de se envolver, de se empenhar, e de se inserir no ambiente dos seus afazeres seja como pessoa ou como profissional. Nas organizações, o comprometimento pode ser percebido a partir da forma como o colaborador desenvolve o seu trabalho, como empenha seus esforços e responsabilidades em executar suas tarefas gerando um vínculo, ou um elo, entre ele e a organização, baseado nos seus valores (VIEIRA e GOMES 2013).

Portanto, os valores de uma empresa podem ser percebidos pelos indivíduos no contexto organizacional ou serem construídos pela própria 
organização na medida em que reconhece para si a importância de assumir determinados princípios, favorecendo, junto aos colaboradores, a noção de que tais valores fazem parte de sua identidade organizacional (CROZATTI, 1998).

Segundo Giddens (2002) esse processo de construção de identidade de uma organização se realiza pelas escolhas e decisões pessoais de cada um, as quais se refletem em todos os contextos sociais de que este indivíduo participa. E essa identificação organizacional, segundo Scott e Lane (2000), se intensifica na medida em que há um alinhamento maior entre os valores do indivíduo e os da própria organização em que ele atua, deixando claro que todos esses fatores reforçam a noção de que o alinhamento de valores fortalece a identidade pessoal e proporciona maior integridade e segurança ontológica ao indivíduo, ou seja, um sentido que se baseie na ordem e continuidade a respeito de suas próprias experiências, e assim favorece a identificação organizacional.

Para que se crie um ambiente que promova tais transformações, os princípios da Gestão Democrática têm demonstrado ser um processo de evolução da sociedade que busca esse desenvolvimento através da participação. Brugué (2008) propõe a direção de uma gestão democrática participativa, uma administração deliberativa, cujo principal instrumento seja 0 diálogo com a sociedade para o enfrentamento de situações complexas e que exigem soluções negociadas e criativas, para que se possa propor e alcançar objetivos substantivos e não apenas instrumentais.

Em organizações públicas, a gestão democrático-participativa se caracteriza por uma ação local, descentralizada, intersetorializada por políticas e programas de articulação entre as esferas de poder governamental.

A intersetorialidade é uma prática social que vem sendo construída com base na existência de profundas insatisfações, principalmente no que se refere à capacidade das organizações em dar resposta às demandas sociais e aos problemas complexos vivenciados pelos cidadãos. (CKAGNAZAROFF; MOTA, 2003, p. 31).

Esta gestão adota como prioridade as demandas das classes populares, realizando uma inversão das gestões tradicionais que privilegiam os grupos de poder já pré-estabelecidos. Ela prevê o acesso da população aos serviços essenciais e privilegia os interesses populares, tidos como garantia de direitos e não mero assistencialismo, bem como amplia o processo de democratização com a adoção de instrumentos e mecanismos de participação social. (GONÇALVES, KAUCHAK \& MOREIRA, 2015)

Segundo Borges e Tamayo (2001), as exigências fundamentais em que passam as organizações para a estruturação de um modelo eficiente de gestão democrática são decorrentes de três princípios norteadores: 0 
primeiro trata da necessidade de compatibilizar os interesses individuais e os coletivos, uma vez que a relação entre indivíduo e grupo seja inevitável; o segundo é sobre o estabelecimento de uma estrutura que garanta o alcance das metas e objetivos organizacionais, e o terceiro se faz pelo relacionamento entre a organização e o ambiente físico e social.

Como uma forma prática em que aconteça de fato a participação da sociedade, Brugué (2008) propõe a criação de um plano que estabeleça as diretrizes básicas para o desenvolvimento de um ambiente democrático, como a criação de vários objetivos pertinentes à participação do cidadão, entre eles 0 desenvolvimento de mecanismos de atuação, a definição do quadro participativo para promover instrumentos e protocolos de ação para ouvir os cidadãos e por último o apoio e aconselhamento às políticas de participação cidadã no nível local.

\section{COMPORTAMENTO E CIDADANIA ORGANIZACIONAL}

Hábitos, atitudes e comportamento são variáveis que resultam das características de uma determinada cultura. Enquanto os hábitos ocorrem como ações realizadas pelo indivíduo em resposta aos condicionamentos culturais, exemplo, seguir uma determinada religião em função da prática semanal da família ir aos cultos, as atitudes podem ser entendidas como ações conscientes realizadas pelo indivíduo em resposta aos desafios culturais, exemplo, a escolha de um determinado político em detrimento aos demais. Em sua amplitude, o comportamento passar a ser entendido como o conjunto de hábitos e atitudes observados, razoavelmente padronizados em um grupo de pessoas, que expressa sua identidade e nível de coesão (CROZATTI, 1998).

Ao extrapolar o conceito para 0 ambiente empresarial, 0 comportamento organizacional (CO) refere-se às questões como competitividade, comprometimento dos colaboradores, aumento da produtividade dentro das organizações. Todavia, Vieira e Gomes (2013) descrevem que as mudanças que ocorrem no ambiente organizacional devem partir inicialmente do pressuposto de que as organizações precisam se adequar às novas exigências do mercado e para tanto, elas devem buscar o alinhamento de seus processos e estruturas aos novos modelos organizacionais, que são baseados na coletividade, nos resultados e no comprometimento. E quando se fala em coletividade a atenção à necessidade de atitudes de cidadania organizacional deve ser redobrada.

Para uma melhor compreensão sobre comportamento de cidadania organizacional (CCO) é preciso inicialmente enxergar as organizações como sistemas de cooperação que são operados pelos recursos 
humanos e não apenas como um produto da engenharia mecânica, como foi difundido pela Escola de Administração Cientifica, conforme destacado por (ANDRADE, ESTIVALETE E COSTA 2018).

Outro aspecto relevante é que a abrangência das instituições extrapola o ambiente organizacional, pois o fato de ser membro de uma organização não implica a sua exclusão de uma determinada sociedade, pelo contrário, também implica ser cidadão na comunidade em que esta existe (KATZ e KAHN, 1978). E nesse ponto a cidadania organizacional em nada se diferencia da cidadania social, pois a mesma tem a sua a relação entre direitos e deveres, e como colaborador, durante suas atividades laborativas no ambiente de trabalho essa relação profissional ultrapassa os limites hierárquicos e de subordinação no objetivo de atingir com eficácia os valores organizacionais (BARSANO, 2002).

Em seus estudos Orgam (1988), define outras cinco dimensões que definem o comportamento de cidadania organizacional; 1) Altruísmo, como um comportamento discricionário por parte dos trabalhadores, 2) Conscienciosidade, comportamento que vai além das regras e normas estabelecidas pela empresa, 3) Desportivismo, disposição dos trabalhadores em tolerar, sem tantas queixas, momentos desfavoráveis, 4) Cortesia, com objetivo de prevenir ocorrências de problemas e 5) Virtude cívica, comportamento de participação e envolvimento na vida organizacional.

No mesmo empenho em desenvolver uma escala de cidadania organizacional, Borman e Motowidlo (1993) elencam cinco pontos que compreendem esse tipo de comportamento: 1) persistir com entusiasmo e esforço extra quando necessário para executar com sucesso as próprias tarefas; 2) voluntariar-se para executar tarefas não prescritas para o cargo; 3) ajudar e cooperar com os outros; 4) cumprir as regras e procedimentos organizacionais mesmo quando isso é pessoalmente inconveniente; 5) apoiar e defender os objetivos organizacionais.

Verifica-se, portanto que, a pertinência dos aspectos culturais e sua forte influência sobre o comportamento dos colaboradores, ao compreender que as pessoas que se identificam podem ver a si mesmas como personificação da organização, Mael e Ashforth (1995), por isso torna-se imprescindível ressaltar a importância de definir uma gestão educacional democrática a partir de uma cultura que defina claramente seus valores, com potencial de promover uma identidade organizacional que influenciará no comportamento em cidadania organizacional.

Ao analisar o conceito de comportamento em cidadania organizacional por uma abordagem política, referindo-se a uma herança cultural e filosófica do termo "cidadania", Graham (1991) propõe um modelo alternativo, porém equivalente organizacional da responsabilidade cívica, 
definindo-o como um conceito global que inclui todos os comportamentos positivos relevantes e aponta três categorias para tais comportamentos; a) obediência organizacional; b) lealdade organizacional e c) participação organizacional.

\title{
3. AMBIENTE EDUCACIONAL - PRIORIDADES E PROCEDIMENTOS PARA GESTÀO DEMOCRÁTICA NO ÂMBITO DAS ETECs.
}

\subsection{AS ETECs NO ESTADO DE SÃO PAULO}

Com base nas diretrizes da Nova Gestão Pública, modelo de gestão do sistema público implantado nas décadas de 90 pela Administração Pública, na qual Bresser-Pereira (1997) se refere, verifica-se a inviabilidade da proposta conservadora de um Estado mínimo, porém estas reformas revelaram a verdadeira natureza na condição necessária da reconstrução do Estado e para que este pudesse realizar não apenas suas tarefas clássicas de garantia da propriedade e dos contratos, mas também seu papel de garantidor dos direitos sociais e de promotor da competitividade do seu respectivo país.

Essa nova postura da Gestão Pública, estendida às organizações de ensino, na qual estabelece o objetivo pela descentralização do movimento administrativo e pedagógico e assim promover uma maior autonomia, considerando as inovações da implantação do processo que envolve a gestão participativa, utilizando-se de várias ferramentas que compartilham as decisões estratégicas da escola objetivando promover um ambiente crítico-reflexivo ao dar voz a diferentes agentes.

Esses princípios são regulamentados no Regimento Comum do Centro Paula Souza, capítulo II: Dos Princípios e Das Finalidades e artigo 3ㅜ,

"Os princípios de gestão democrática nortearão a gestão da Etec, valorizando as relações baseadas no diálogo e no consenso, tendo como práticas a participação, a discussão coletiva e a autonomia".

E em seu parágrafo único ressalta que:

\begin{abstract}
"A participação deverá possibilitar a todos os membros da comunidade escolar o comprometimento no processo de tomada de decisões para a organização e para 0 funcionamento da Etec e propiciar um clima de trabalho favorável a uma maior aproximação entre todos os segmentos das Etecs."
\end{abstract}

Para auxiliar no processo de implantação da Gestão participativa do Centro Paula Souza em suas unidades escolares e ao mesmo tempo como uma ferramenta de qualidade, foi desenvolvido o Observatório Escolar. Criado 
em 1998 o Observatório possibilitou às unidades escolares garantir a difusão das boas práticas e estabelecer procedimentos comuns.

Segundo Ramos (2011) o Observatório Escolar do Centro Paula Souza é um sistema de autoavaliação que tem como objetivo propor a melhoria contínua através de boas práticas de gestão. Pois com o propósito de promover uma Escola Técnica com qualidade, o Observatório Escolar segue além da análise de estrutura física ao tentar mensurar um corpo docente comprometido e dedicado, e também na articulação entre a equipe de gestão e a comunidade na oferta de cursos adequados aos arranjos produtivos locais.

Desta forma, o processo de autoavaliação propõe estabelecer critérios claros para os procedimentos de promoção, advertências e desligamentos dos diferentes atores que compõem a comunidade escolar, promovendo alto índice de alunos diplomados com baixo índice de evasão e a inserção de profissionais concluintes no mundo do trabalho.

Os principais objetivos do Observatório Escolar estão em:

- Criar parâmetros e subsídios para estabelecer diretrizes necessárias à elevação do padrão de desempenho e à melhoria contínua da qualidade e pertinência dos processos e produtos das escolas.

- Criar uma cultura de autoavaliação que fortaleça a autonomia responsável da gestão escolar.

- Promover a disseminação do processo de avaliação, incorporando-o à cultura organizacional da escola, enquanto prática efetiva da gestão.

- Implantar uma sistemática de avaliação formativa processual, emancipatória e democrática.

- Promover a reflexão sobre o significado do conjunto das atividades desenvolvidas na escola e suas finalidades.

- Fortalecer as relações de cooperação entre os diferentes segmentos da comunidade escolar (RAMOS 2011).

Além desses fatores objetivos, em educação, existem outros que nunca poderão ser desconsiderados tais como: a ampliação do conceito de participação cidadã oferecido pelas escolas; a possibilidade do surgimento de lideranças comunitárias e/ou vinculadas às categorias profissionais; a possibilidade, rara no Brasil, de ter na escola pública, alunos de diferentes origens étnicas e sociais.

O Observatório Escolar mensura o desempenho escolar de cada unidade de ensino através de 7 blocos de gestão: Gestão Pedagógica; Gestão do Espaço Físico; Gestão Participativa; Gestão de Pessoas; Gestão de Documentos; Gestão de Parcerias; Gestão dos Serviços de Apoio (RAMOS 2011).

\subsection{O CASO DE UMA ETEC NA REGIÃO DE FRANCA}


Para inicialização do conhecimento da realidade do tema no âmbito organizacional, após a pesquisa bibliográfica acerca dos temas: Cultura, Identidade, Gestão Democrática e Cidadania Organizacional, foi realizada uma análise documental e de observação em uma escola de Ensino Médio e Técnico (ETEC) localizada numa cidade na região de Franca. A escola oferece cursos nas diversas áreas técnicas, além do ensino médio regular. Atualmente conta com aproximadamente 1.200 alunos, 70 professores e 20 funcionários administrativos.

A seleção da mesma se deu em virtude da observação, do pesquisador, de que entre 2013 a 2018 houve alteração no processo de gestão e uma evolução do comparativo deste período apontada pela ferramenta de avaliação do "Observatório Escolar"., conforme demonstrado no Gráfico 1.

Gráfico 1 - Resultado de Avaliação de Desempenho Anual

\section{Observatório Escolar - Comparativo 2013 a 2018}

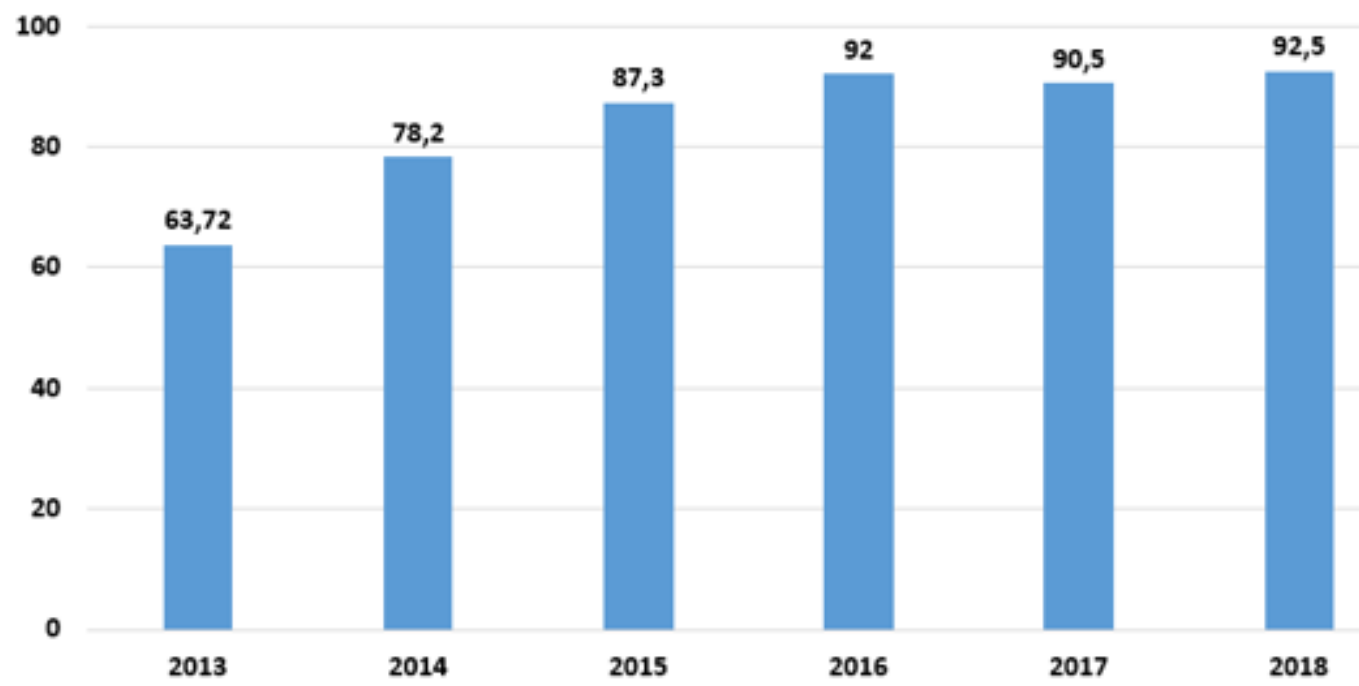

Fonte: Gráfico apresentado na Reunião de Planejamento da unidade escolar no ano de 2019.

Esse período refere-se à gestão atual que iniciou suas atividades em 2012 e está em seu segundo mandato o qual encerrará em 2020.

Assim, surgiu o interesse de conhecer os aspectos da cultura organizacional, da gestão democrática e de cidadania organizacional que estão envolvidos nas atividades entre 2013 e 2018.

Neste princípio foi fundamental o apoio de ações que visavam promover o fortalecimento das inter-relações entre os diferentes agentes para 0 estabelecimento de uma educação cidadã e de qualidade à comunidade local. 
Para apontar os pontos positivos desta gestão em relação a gestão anterior será necessário apontar aspectos objetivos e oficiais documentados

Os aspectos observados na gestão neste período são classificados, neste estudo, entre os grupos:

1) Continuidade: são as atividades que já existiam na gestão anterior e foram conservadas.

2) Melhoria: atividades que já existiam, porém sofreram alterações.

3) Inclusão: atividades implementadas no período em análise

4) Exclusão: atividades que foram excluídas.

Quadro 2 - Análise das atividades no período de 2013 a 2018.

\begin{tabular}{|c|c|c|c|}
\hline ANÁLISE & ATIVIDADES & AÇÕES & DOCUMENTO \\
\hline \multirow{2}{*}{ CONTINUIDADE } & $\begin{array}{l}\text { Direção Acadêmica e } \\
\text { Administrativa }\end{array}$ & $\begin{array}{l}\text { Manteve a mesma } \\
\text { equipe de } \\
\text { colaboradores }\end{array}$ & Observação \\
\hline & $\begin{array}{l}\text { Feira de Exposição } \\
\text { Tecnológica para o ensino } \\
\text { técnico }\end{array}$ & $\begin{array}{l}\text { Manteve o evento para } \\
\text { essa modalidade de } \\
\text { ensino }\end{array}$ & $\begin{array}{l}\text { Plano Plurianual de } \\
\text { Gestão }\end{array}$ \\
\hline \multirow{4}{*}{ MELHORIA } & $\begin{array}{l}\text { Coordenação Classe } \\
\text { Descentralizada }\end{array}$ & $\begin{array}{l}\text { De Professor } \\
\text { Responsável para } \\
\text { Coordenador }\end{array}$ & Portaria 281/2013 \\
\hline & $\begin{array}{l}\text { Reestruturação } \\
\text { tecnológica dos ambientes }\end{array}$ & $\begin{array}{l}\text { Aparelhos multimídia } \\
\text { em todas as salas e } \\
\text { algumas com ar } \\
\text { condicionado. } \\
\text { Recursos audiovisuais } \\
\text { para o auditório e } \\
\text { readequação de uma } \\
\text { nova sala para } \\
\text { coordenação }\end{array}$ & Atas de Reunião \\
\hline & $\begin{array}{l}\text { Atribuição de } \\
\text { responsabilidades ao } \\
\text { Grêmio Estudantil }\end{array}$ & $\begin{array}{l}\text { Organização de } \\
\text { eventos estudantis }\end{array}$ & Atas de Reunião \\
\hline & Biblioteca & $\begin{array}{l}\text { Readequação das } \\
\text { normas e aquisição de } \\
\text { acervo }\end{array}$ & Ata de Conselho \\
\hline \multirow{4}{*}{ INCLUSÃO } & Comitê de Gestão & $\begin{array}{l}\text { Inclusão do Orientador } \\
\text { Educacional }\end{array}$ & Portaria 082/2013 \\
\hline & $\begin{array}{l}\text { Projeto de Intercâmbio } \\
\text { Internacional }\end{array}$ & $\begin{array}{l}\text { Cursos no exterior } \\
\text { através de parceria do } \\
\text { CEETEPS }\end{array}$ & Ata de Conselho \\
\hline & Projetos Extra-curriculares & $\begin{array}{l}\text { Aulas no período } \\
\text { oposto como reforço }\end{array}$ & $\begin{array}{l}\text { Plano Plurianual de } \\
\text { Gestão }\end{array}$ \\
\hline & Novos cursos & $\begin{array}{l}\text { Etim em } \\
\text { Desenvolvimento de } \\
\text { Sistemas, M-Tec em } \\
\text { Administração. }\end{array}$ & $\begin{array}{l}\text { Etim - Decreto } \\
8.268 / 2014 \\
\text { M-Tec - Portaria } \\
1338 / 2017\end{array}$ \\
\hline
\end{tabular}




\begin{tabular}{|c|l|l|l|}
\hline \multirow{2}{*}{} & Projeto Café com o Diretor & $\begin{array}{l}\text { Reuniões trimestrais } \\
\text { dos Representantes } \\
\text { de Sala com o Diretor }\end{array}$ & Ata de Reunião \\
\cline { 2 - 4 } & Festa das Nações & $\begin{array}{l}\text { Evento de integração } \\
\text { da família do aluno } \\
\text { com o ambiente } \\
\text { escolar }\end{array}$ & Ata de Reunião \\
\cline { 2 - 4 } & Feira do Troca & $\begin{array}{l}\text { Projeto de incentivo à } \\
\text { leitura através da troca } \\
\text { de exemplares }\end{array}$ & $\begin{array}{l}\text { Plano Plurianual de } \\
\text { Gestão }\end{array}$ \\
\hline EXCLUSO & $\begin{array}{l}\text { Feira Tecnológica para o } \\
\text { Ensino Médio }\end{array}$ & $\begin{array}{l}\text { Foi excluída para essa } \\
\text { modalidade }\end{array}$ & Ata de Reunião \\
\hline
\end{tabular}

Fonte: Adaptado pelo autor, 2019.

I) Continuidade:

As atividades que foram apontadas como Continuidade, pois já existiam na gestão anterior e foram conservadas, são:

a) Manutenção da equipe de colaboradores tanto da Direção Acadêmica quanto da Direção Administrativa

b) Continuidade da Feira de Exposição Tecnológica - Expobadran para o ensino Técnico

II) Melhoria:

As atividades que foram apontadas como Melhoria, pois já existiam na gestão anterior, porém foram melhoradas.

a) O Professor Responsável pelas unidades descentralizadas com 10 horas atividades passou a ser Coordenador de Classe Descentralizada com 25 horas atividades;

b) Houve uma reestruturação dos ambientes: todas as salas de aulas receberam projetores multimídia e caixas de som; auditório passou a ter recursos audiovisuais mais avançados; houve realocação de uma sala ampla e mobiliário adequado para os coordenadores de curso;

c) O Grêmio Estudantil passou a ter maiores atribuições na criação e desenvolvimento de eventos junto aos alunos;

d) A biblioteca, através de verbas da Associação de Pais e Mestres aumentou seu acervo;

III) Inclusão:

As atividades que foram apontadas como Inclusão, foram implementadas na gestão atual.

a) Foi incluído o cargo de Orientador Educacional para mediar os conflitos dos alunos junto à Direção Escolar; 
b) Projeto Intercambio Escolar, promovido pelo Centro Paula Souza à alunos com melhor aproveitamento pedagógico, com a possibilidade dos mesmos conhecerem outras culturas e apropriar-se de conhecimentos tecnológicos de outros países;

c) Inserção de Projetos Extracurriculares desenvolvidos no período oposto para apoio às matérias do currículo básico;

d) Inserção de novas modalidades de cursos para o ensino médio, como o ensino médio integrado, o Etim em Desenvolvimento de Sistemas, o médio Técnico, o M-Tec, junção do ensino técnico em administração com o ensino médio.

e) Inserção do Projeto Café com o Diretor, com o propósito de aproximar os alunos à direção escolar;

f) Festas das Nações, evento anual com comidas típicas a fim de integrar a comunidade local, principalmente os familiares dos estudantes à unidade escolar.

g) Feira da Troca, um projeto estudantil com objetivo de promover a leitura a partir da troca de livros, gibis e mangás entre os próprios alunos;

IV) Exclusão

As atividades que foram apontadas na Exclusão, foram definitivamente excluídas das atividades da gestão.

a) A exclusão da Expobadran, Feira Tecnológica para alunos do ensino médio regular do período matutino.

As ações colocadas em prática objetivaram uma maior transparência na Gestão Educacional da unidade, com a intenção de colocar todos os agentes como parte integrante e decisiva na busca de soluções para os problemas que afetam o cotidiano da escola, elevando o nível do desempenho anual desta unidade de ensino.

\section{CONSIDERAÇÕES FINAIS}

Como pode-se observar através desse estudo que, a descentralização do poder de decisão pode gerar uma maior flexibilidade aos participantes do processo de gestão ao promover maior liberdade de atuação e melhor ajustamento das demandas internas ao ambiente externo da organização.

Torna-se imprescindível ressaltar a importância de definir uma gestão educacional democrática a partir de uma cultura que defina claramente seus valores, com potencial de promover uma identidade organizacional que influenciará no comportamento em cidadania organizacional de toda equipe 
escolar, não somente a participação da equipe de direção, mas também dos professores, funcionários, pais, alunos, enfim, toda comunidade escolar deve estar engajada em prol dos objetivos, sempre priorizando a qualidade da educação e melhoramentos na vida da comunidade.

A gestão democrática é uma ferramenta de grande valia na construção de práticas educativas, o que implica em mudanças culturais através das interações dos envolvidos na prática de objetivos compartilhados e no processo de cooperação. Verifica-se que quando há um alinhamento entre os valores da pessoa e os da empresa, essa identidade organizacional passar a ser percebida como um senso de unidade e pertencimento entre todos os membros.

Deste modo, os envolvidos num processo democrático têm grande potencial para exercerem comportamento de cidadania organizacional, no sentido do comprometimento espontâneo, com iniciativas de voluntariado e colaborativas com proatividade, na qual passam a ter com a própria função que exercem.

Nesse contexto o gestor passa a ter a responsabilidade de deliberar o processo de organização e gestão pedagógica, no sentido de imprimir uma gestão com lógica, criatividade e diálogo em detrimento da luta pelo poder. Descrevendo-se assim como o melhor caminho para estimular valores e procedimentos que direcionam as ações de cidadania organizacional e ainda, com sua continuidade ao longo do tempo tais procedimentos implicaram na revaloração da cultura e identidade organizacional corroborando com uma gestão democrática sustentável ao longo do tempo.

Contribuindo assim na promoção de melhorias gerais no ensino e aprendizagem, pois a escola ao promover um ensino permeado de cidadania, sob a direção de uma gestão democrática, passa a servir como exemplo entre seus agentes criando o senso da cidadania organizacional, o que promove melhorias na qualidade de vida dentro e fora dos muros das escolas.

\section{Referências}

ANDRADE, T., ESTIVALETE, V. F. B. e COSTA, V.F. "Comportamento de cidadania organizacional: versão brasileira da escala Comportamentos de Cidadania Organizacional para Trabalhadores do Conhecimento." Disponível em:<http;//www.scieleo.br/scielo.php?script=sci_abstract\&pid=S1679...Ing=en... iso >. Acesso em 03 abr. 2019

BARSANO, P. R., “Ética e Cidadania Organizacional”, São Paulo, Érica, 2012, 1a edição. 
BORMAN, W. C., \& MOTOWIDLO, S. J. (1993). Expanting the criterion domain to include elements of contextual performance. In N. Schmitt, \& W. Borman, Personal Selection in Organizations (pp. 71-98). San Francisco : Jossey-Bass.

BRUGUE, Q. T., Modernizar la administración através de la participación: la experiencia de la Generalitat de Catalunya. Revista internacional de Organizaciones (RIO), № 1, Diciembre 2008, 39-53. Disponível em https://www.researchgate.net/publication/46412090 Modernizar la Administrac ion a traves de la participacion la experiencia de la Generalitat de Catal unya Modernizar la Administracion a traves de la participacion la experie ncia de la Generalitat de Ca. Acesso em 05 abr. 2019

BORGES, L. O., TAMAYO, A., A estrutura cognitiva do significado do trabalho. rPOT 1 Volume 11 Número 21 Julho - Dezembro 2001. Disponível em http://pepsic.bvsalud.org/pdf/rpot/v1n2/v1n2a02.pdf. Acesso em 04 abr. 2019

BRESSER-PEREIRA, L.C. 1934 - A Reforma do estado dos anos 90: lógica e mecanismos de controle. Brasília: Ministério da Administração Federal e Reforma do Estado, 1997. 58 p. (Cadernos MARE da reforma do estado; v. 1)

CAVAZOTE, F.S.C.N, MORENO JR., V. A. TURANO, L. M. "Cultura de aprendizagem contínua, atitudes e desempenho no trabalho: uma comparação entre empresas do setor público e privado." Disponível em: $<$ http://www.scielo.br/pdf/rap/v49n6/0034-7612-rap-49-06-01555.pdf $>$. Acesso em 05 abr. 2019

"Identificação organizacional entre funcionários públicos brasileiros: um estudo no setor cultural". Disponível em: <http:// www.scielo.br/pdf/rbgn/v19n64/1806-4892-rbgn-19-64-00289.pdf>. Acesso em 04 abr. 2019

CKAGNAZAROFF, I.B., MOTA, N.R.. Considerações sobre a relação entre descentralização e intersetorialidade como estratégias de modernização de prefeituras municipais. Revista E \& G Economia e Gestão, Belo Horizonte, v. 3 , n. 6 , p. 23-41, dez. 2003. Disponível em: www.spell.org.br/documentos/download/36443. Acesso em 14/07/2019.

CROZATI, Jaime, Modelo de Gestão e Cultura Organizacional - Conceitos e Interações, Caderno de Estudos, São Paulo, FIPECAFI, v.10, n. 18, p. - , maio/agosto 1998. Disponível em: http://www.scielo.br/pdf/cest/n18/n18a04.pdf. Acesso em 03 abr.2019

FLEURY, M. T. L. Estórias, mitos, heróis e cultura organizacional e relações do trabalho. Rev. Adm. Empr. Rio de Janeiro, ou./dez. 1987. Disponível em http://www.scielo.br/pdf/rae/v27n4/v27n4a06.pdf. Acesso em 27 out. 2018. 
GIDDENS, Anthony, Modernidade e identidade; tradução, Plínio Dentzien. Rio de Janeiro: Jorge Zahar Ed., 2002.

GRAHAM, J. W. (1991). An essay on organizational citizenship behavior, Employee Responsibilities and Rights Journal , 4, 249-270. Disponível em https://vulms.vu.edu.pk/Courses/STAT730/Downloads/An\%20essay\%20on\%20 organizational\%20citizenship\%20behavior.pdf. Acesso em 25 ago. 2019

GONÇALVES, M.T., KAUCHAKJ, S., MOREIRA, T.A., Modalidades de Gestão Social no Brasil, InSitu (São Paulo), Vol.1 N.2, p. 131-154, 2015. Disponível em www.revistaseletronicas.fiamfaam.br > situs > article > download > pdf. Acesso em 24 jul. 2018.

KATZ, D., KAHN R.L., The social pshichology of organizations. New York: Wiley, 1966, 489 p.Dept. Pshicol. and Survey Research Center, Un. Michigan, Ann Arbor, Ml. Disponível em http://garfield.library.upenn.edu/classics1980/A1980JY55100001.pdf. Acesso em 25 ago. 2019

MARCONI, M.A., PRESOTTO, M. A. M., Antropologia: uma introdução, $7^{\text {ạ }}$ ed. - 3 reimpr - São Paulo: Atlas 2010

MAEL, F.A. ASHFORTH, B.E. Loyal from day one: biodata, organization identification, and turnover among newcomers, Personnel Psychology, 1995, 48.4 Disponível em https://www.researchgate.net/profile/Blake Ashforth/publication/229505526 Lo yal from day one Biodata organizational identification and turnover among newcomers/links/5af9c5d00f7e9b3b0beefbb1/Loyal-from-day-one-Biodataorganizational-identification-and-turnover-amongnewcomers.pdf?origin=publication detail. Acesso em 24 jul 2018

MENDES, A. M., TAMAYO, A., Valores Organizacionais e prazer-sofrimento no trabalho. Psico-USF, v.6, n.1, p.39-46, jan./jun. 2001. Disponível em http://pepsic.bvsalud.org/pdf/psicousf/v6n1/v6n1a06.pdf. Acesso em 05 ago.2019.

MIGUEL, L. A. P.; TEIXEIRA, M. L. "Valores organizacionais e criação do conhecimento organizacional inovador". RAC, Curitiba, v. 13, n. 1, p. 36-56, jan./mar. 2009. Disponível em: < http://www.scielo.br/pdf/rac/v13n1/a04v13n1>. Acesso em: 27 out. 2018.

NEVES, P. C. e PAIXÃO, R. "Comportamentos de cidadania organizacional: uma revisão do conceito". disponível em: <http:// https://www.researchgate.net/.../276419122 Comportamentos de cidadania O rganizacional>. Acesso em 04 abr.2019

ORGAN, D. W. Organizational citizenship behavior: The good soldier syndrome. Canada: Lexington Books, 1998. Disponível em 
https://www.researchgate.net/profile/Blake Ashforth/publication/229505526 Lo yal from day one Biodata organizational identification and turnover among newcomers/links/5af9c5d00f7e9b3b0beefbb1/Loyal-from-day-one-Biodataorganizational-identification-and-turnover-amongnewcomers.pdf?origin=publication detail. Acesso em 25 jun. 2018

PIRES, J. C. S.; MACEDO, K. B. "Cultura organizacional em organizações públicas no Brasil." Rev. Adm. Pública, Rio de Janeiro, v. 40, n. 1, p. 81-105, 2006.

RAMOS, I. M. L., OBSERVATÓRIO ESCOLAR: A autoavaliação nas Etecs: um caminho construído com múltiplos olhares. Unidade de Ensino Médio e Técnico Centro Paula Souza, 2011.

REGIMENTO COMUM, Escolas Técnicas Estaduais do Centro Estadual de Educação Tecnológica Paula Souza, Deliberação CEETEPS № 003, de 18-72013.

RUSSO, G.M., "Diagnóstico da Cultura Organizacional", Rio de Janeiro: Elsevier-SP Dedix:2010

SCHEIN, E. H. "Cultura organizacional e liderança." São Paulo: Atlas, 2009.

SCOTT, S.G., LANE, V.R., A Stakeholder approach to Organizational Identity, Academy of Management Review, 2000, vol. 25, n. 1, 4362. Disponível em https://www.researchgate.net/publication/272581526 A Stakeholder Approach to Organizational Identity The Academy of Management Rewiew. Acesso em 25 jul.2019

SILVA, L. M. T., et al. "Cultura Organizacional e Liderança: Uma Relação Possível?". Disponível em: <http:// www.scielo.br/pdf/rausp/v48n1/04.pdf>. Acesso em 05 abr. 2019

SILVA, L. P.; FADUL, É. "A produção científica sobre cultura organizacional em organizações públicas no período de 1997 a 2007: um convite à reflexão" Revista de Administração Contemporânea, v. 14, n. 4, p. 651-669, 2010.

TAMAYO, Á. "Valores organizacionais: sua relação com satisfação no trabalho, cidadania organizacional e comprometimento afetivo." Revista de Administração, São Paulo: v. 33, n. 3, 1998. Disponível em: $<$ http://rausp.usp.br/wp-content/uploads/files/3303056.pdf>. Acesso em 04 abr. 2019.

TAMAYO, A.; MENDES, A. M.; PAZ, M. G. T. "Inventário de valores organizacionais". Artigos - Estudos de Psicologia. 2000, p. 289-315. Disponível em: <http://www.scielo.br/pdf/epsic/v5n2/a02v05n2.pdf>. Acesso em 05 abr. 2019 
VIEIRA, M. S. O. C. e GOMES D. C., "Valores Organizacionais numa Instituição Pública de Ensino do RN". Disponível em: <http:// https://www.researchgate.net/publication/287516374 VALORES ORGANIZACI ONAIS... >. Acesso em 04 abr. 2019 


\title{
GESTÃO PÚBLICA E EDUCAÇÃO INFANTIL DE QUALIDADE
}

\author{
MALTA, Deise Aparecida Silva \\ Universidade Federal de São Carlos \\ deisesmalta@hotmail.com \\ SOMMERHALDER, Aline \\ Universidade Federal de São Carlos \\ sommeraline1@gmail.com \\ MÁXIMO, Heliny de Carvalho \\ Universidade Federal de São Carlos \\ hlymax08@gmail.com
}

\section{INTRODUÇÃO}

No mundo todo há uma expansão considerável da educação infantil em virtude da necessidade dos familiares de colocar seus filhos em uma instituição educativa para que possam exercer suas atividades profissionais. Esse fato também ocorre devido a relevância do trabalho destinado à criança pequena para seu desenvolvimento e à constatação de que o cidadão têm direito de receber educação desde o nascimento (ABREU, 2004). Desse modo, a educação infantil ganha notoriedade, e passa a fazer parte das discussões das políticas públicas.
A escolarização precoce torna-se um imperativo de vida moderna. Ou seja, a educação infantil em instituições especializadas busca mitigar o empobrecimento do universo afetivo, enseja o aprendizado da convivência em grupo e, assim, supre de alguma forma, as deficiências da "família ausente" que já não têm como assegurar plenamente 0 chamado desenvolvimento integral da criança. (CARNEIRO, 2012, p.220)

No Brasil, observa-se que apesar da educação infantil ter conseguido espaço nos debates das políticas públicas, o que compete a gestão, na maioria das vezes não é concretizado, a organização, execução, manutenção e controle das atividades, no âmbito educacional não são eficientes, embora o século XX tenha sido marcado por várias mudanças na gestão das políticas públicas devido ao avanço das tecnologias de informação e comunicação e a globalização, entre outros.

Como sabemos, a politica educacional se realiza através da elaboração e execução de programas de educação. Conforme Barreto (2003) se faz necessária a instalação, manutenção e administração de prédios escolares com infraestrutura adequada, investimento em recursos humanos e 
materiais apropriados, além da capacitação permanente e a valorização dos profissionais da educação.

Quanto à educação infantil, conforme prevê o Plano Nacional de Educação PNE, para que tenha qualidade é necessário garantir também a ampliação da oferta, alimentação escolar para crianças de estabelecimentos públicos e conveniados, estabelecimento de padrões de qualidade como referência para a avaliação, controle, supervisão e aperfeiçoamento da educação infantil.

O ministério da Educação, embora tenha, desde 1974, um setor para tratar deste assunto, na verdade, jamais desenvolveu uma política coerente sequencial que contabilizasse ideias, corpo técnico para cooperação com os estados e recursos financeiros. Ou seja, ausente dos orçamentos públicos, a educação pré-escolar jamais ultrapassou o terreno das intenções. Abrigada desde 1988 em dispositivo constitucional e, agora, integrada ao conceito de educação básica, é de se esperar que possa desenvolver-se sistematicamente, a exemplo do que ocorre nos países de estrutura educacional sólida. (CARNEIRO, 2012, p. 219)

Podemos concluir que a ampliação do atendimento a melhora da qualidade que garanta a equidade da educação infantil no país, depende do fortalecimento dos sistemas de gestão da administração pública, de um modelo capaz de atender aos desafios apresentados. Para isso, se faz necessária uma visão de futuro, comprometimento com as pessoas e foco no cidadão e na sociedade.

\section{TRAJETÓRIA DA GESTÃO PÚBLICA NO BRASIL}

No decorrer dos tempos, podemos afirmar que projetos políticos distintos predominaram no país, nesse sentido, a gestão pública passou por fases, buscando atingir objetivos traçados conforme seu contexto histórico.

Nesse caminhar, a administração patrimonialista foi o primeiro modelo de administração do Brasil "o Estado era entendido como propriedade do rei" (PEREIRA,1996, p.4). Nesta época, os patrimônios público e o privado não eram bem definidos .

Posteriormente, no regime militar surgiu a administração pública burocrática, com o propósito de ser superior a patrimonialista e atender as demandas da população. Entretanto, esse modelo de governo possui como característica o fato de não priorizar as aspirações de coletividade. Nesse sentido, voltado para si tornou-se lento, oneroso e ineficiente, conforme argumenta Pereira (1996).

Nesse percurso, durante o governo do ex-presidente Fernando Henrique Cardoso, em meados de 1990, a politica gerencial predominou. Diferente da administração burocrática, ela destacou a profissionalização e 
práticas de gestão do setor privado. Embora no discurso se apresenta como participativa, seu caráter é centralizador nas tomadas de decisões. Dentre outros fatores, podemos dizer que esse modelo surgiu devido às transformações do setor produtivo, a globalização, a tecnologia, o aumento do poder das grandes corporações e o enfraquecimento dos governos para controlar os grandes fluxos comerciais e financeiros.

Em contraponto, a administração pública societal, enfatiza a participação da sociedade, através de estratégias que viabilizem gestão com enfoque na participação popular, conforme afirma Paula (2005).

Os dois modelos de gestão gerencial e societal apresentam vantagens e desvantagens que devem ser consideradas e dentre as dificuldades, podemos afirmar que o gerencial não leva em consideração nem incentiva a participação da sociedade, ou seja, sua ênfase está na dimensão estrutural, entretanto, seus métodos contribuem para a eficiência da gestão pública. Já o modelo societal, considera a participação e as necessidades coletivas, seus projetos vão ao encontro do interesse popular, porém, suas decisões não articulam a dimensão social com as demais.

A vertente societal (...), enfatiza principalmente a participação social e procura estruturar um projeto político que repense o modelo de desenvolvimento brasileiro, a estrutura de Estado e o paradigma de gestão. (PAULA, 2005, p.41)

Ao analisar estes tipos de gestão, temos que levar em consideração o momento histórico em que foram adotados, e que a administração pública está em constante transformação. Desse modo, compreendemos que cada proposta colaborou para o atual modelo de gestão pública do país.

Importante ressaltar que, ao se almejar uma gestão de excelência e que objetiva o desenvolvimento sustentável, o cumprimento da legislação e a qualidade dos serviços prestados, as decisões do gestor devem se pautar pelo interesse público e o bem comum. $O$ artigo 37 da Constituição Federal preconiza que, "a administração pública direta e indireta de qualquer dos Poderes da União, dos Estados, do Distrito Federal e dos Municípios obedecerá aos princípios de legalidade, impessoalidade, moralidade, publicidade e eficiência".

É relevante considerar a necessidade da população e incentivar sua participação no planejamento, acompanhamento, avaliação e controle das políticas públicas para se garantir a igualdade e a eficácia nas determinações.

Nas últimas décadas os brasileiros estiveram engajados no processo de redemocratização do país, buscando reformar o Estado e construir um modelo de gestão pública capaz de torná-lo mais aberto às necessidades dos cidadãos brasileiros, mais voltado para o interesse 
público e mais eficiente na coordenação da economia e dos serviços públicos. (PAULA, 2005, p.37)

Em suma, o modelo de gestão pública que atenda as demandas da contemporaneidade, deve considerar além da participação coletiva, a panorâmica cultural do país, os modelos internacionais de modernizações na gestão pública, além de investir em tecnologias gerenciais e na articulação dos demais órgãos públicos e privados.

Sobretudo, administração pública tem o dever de organizar suas ações de acordo com a necessidade dos cidadãos, tendo o compromisso de garantir o direito de todos ao acesso aos serviços públicos de qualidade.

\section{O PERCURSO DAS POLÍTICAS EDUCACIONAIS NO BRASIL}

No âmbito educacional, podemos conceituar as políticas como:

[...] processo permanente de enriquecimento de conhecimento, do saber fazer, mas também e talvez em primeiro lugar, como uma via privilegiada de construção da própria pessoa, das relações entre indivíduos, grupos e nações (UNESCO, 2007, p.12).

No século XX, mais especificamente na década de 30, logo após a chegada do presidente Getúlio Vargas, o sistema educacional brasileiro passa a ser organizado. Assim sendo, no ano de 1930 criou-se o Ministério da Educação e Saúde Pública, sendo que, anteriormente, a educação era tratada pelo Ministério da Justiça.

Partindo do escolanovismo, em 1932, foi publicado o Manifesto dos Pioneiros, que aborda: educação obrigatória, pública, leiga e gratuita, eliminação do dualismo escolar e alega ser dever do estado, fornecer educação. Estas reinvindicações foram atendidas na constituição de 1934 que descrevia um capítulo exclusivo para a educação, em que havia a obrigação de "traçar as diretrizes da educação nacional" (art. 5) e "fixar o plano nacional de educação, compreensivo do ensino em todos os graus e ramos, comuns e especializados" para "coordenar e fiscalizar a sua execução em todo o território do país" (art. 150). Havia a intenção de assegurar a obrigatoriedade da escolaridade primária e implantar um plano de educação que abrangesse todo o país. Nesta época, a substituição do modelo agrário pelo industrial, despertou a atenção para a educação profissional voltada para o mercado de trabalho.

Em 1961 foi criada a Lei de Diretrizes e Bases da Educação, a primeira lei que trata exclusivamente da educação brasileira, fixando diretrizes e bases nacionais. A lei n04024/61 ficou em vigor por dez anos, mas assim que foi publicada já foi considerada ultrapassada, devido ao grande tempo em que ficou em debate. Em 1971, a discussão sobre a nova lei foi concluída e entra 
em vigor a Lei 5692/71, que trouxe diversas mudanças, dentre suas contribuições, podemos destacar: oito anos de duração para o primeiro grau gratuito e obrigatório, ensino supletivo e segundo grau profissionalizante.

No ano de 1962 foi elaborado o primeiro PNE - Plano Nacional de Educação, partindo do "Manifesto dos Pioneiros da Educação Nova" que, avaliando a educação no Brasil, verificou a falta de unidade e realizou um plano de reorganização da educação. O Manifesto dos Pioneiros da Educação pode ser considerado como a primeira iniciativa de elaboração de um plano de educação para o país, reconhecendo a educação como um problema nacional, é o que afirma Azanha (1998).

Na década de 1990, a Conferência Mundial De Jomtien na Tailândia. foi um marco para as mudanças nas politicas educacionais brasileiras. O Brasil assume os compromissos firmados nesta conferencia demonstrando se preocupar com a modernização da educação.

\begin{abstract}
Jamais testemunharemos um outro momento tão propício à renovação do compromisso com o esforço a longo prazo para satisfação das necessidades básicas de aprendizagem de todas as crianças, jovens e adultos. Tal esforço exigirá, contudo, um muito maior e racional aporte de recursos para a educação básica e capacitação do que tem sido feito até o momento. Todavia, os benefícios advindos deste esforço começarão a ser colhidos de imediato, e crescerão um tanto a cada dia, até a solução dos grandes problemas mundiais que hoje enfrentamos. E isso graças, em grande parte, à determinação e perseverança da comunidade internacional na persecução de sua meta: Educação para Todos". (DECLARAÇÃO MUNDIAL SOBRE EDUCAÇÃO PARA TODOS, 1998).
\end{abstract}

Na década de 1990 também podemos citar como relevante, os PCNs Parâmetros Nacionais Curriculares, visto que, este documento norteia o fazer pedagógico das Secretarias Estaduais e Municipais de Educação, quanto à seleção de conteúdos e orientações didáticas. Com a intenção de assegurar a melhoria da qualidade do ensino, em 2001, foi apresentado e aprovado o novo PNE (Plano Nacional de Educação) que prescreve sobre objetivos e metas para todas as modalidades de educação no país a serem cumpridas no prazo de dez anos.

Como podemos observar, ao longo do tempo, foram realizas várias tentativas de elevar o nível da educação. No ano de 2003, o governo lança o Programa do Tamanho do Brasil cujo foco é a democratização do ensino, a universalização e a gestão democrática. Em 2006, o Ensino Fundamental foi ampliado para 9 anos, iniciando-se aos 6 anos de idade, no qual se almejava melhorar a qualidade da escolarização com a ampliação do tempo de permanência na escola, e em 2007, foi aprovado o PDE Plano de 
Desenvolvimento da Educação, um programa do governo que visa diminuir a enorme defasagem que 0 Brasil apresenta em relação aos países desenvolvidos, visto que, todas as iniciativas do governo ao não foram suficientes para melhorar a qualidade da educação

Dentre outras empreitadas do governo para garantir a excelência da educação, em 2013, a Educação Infantil passou a ser obrigatória (com ingresso aos 4 anos, mas ainda sem atendimento em creches), com o objetivo de aumentar os anos de permanência das crianças nas escolas.

O sistema educacional é um tema que precisa ser equacionado no Brasil, de acordo com o educador Demerval Saviani (1996) que relata que, no país existe apenas uma estrutura e não um sistema nacional de educação. Segundo ele, há necessidade de três condições básicas: conhecimento dos problemas educacionais de determinada solução histórico geográfica, das estruturas da realidade e da teoria da educação.

\section{A EDUCAÇÃO INFANTIL NO CONTEXTO DAS POLÍTICAS PÚBLICAS EDUCACIONAIS}

Desde a década de 1920, a educação infantil é tema de debate de modo mais aprofundado com preocupação de contraposição ao modelo escolar eclesiástico. Dessa maneira, no Movimento Escola Nova discutia-se a educação pré escolar como base do sistema escolar. Em 1961, a Lei de Diretrizes e Bases da Educação (LDB) n. 4024/61 determina a inclusão das escolas maternais e os jardins da infância no sistema de ensino. A educação pré-primária destina-se aos menores até sete anos, e será ministrada em escolas maternais ou jardins da infância. ( Art. 23)

Esta lei foi revogada pela Lei no5692, de 1971 que estabeleceu: "Os sistemas velarão para que as crianças de idade inferior a sete anos recebam conveniente educação em escolas maternais, jardins da infância ou instituições equivalentes. (art. 19). Desta forma, os sistemas passaram a ter a responsabilidade de normatizar a educação de crianças pequenas, resultando em variadas regras. Foi nesta época que houve uma grande expansão das escolas de educação infantil no país.

Entretanto, educação Infantil até a Constituição Federal de 1988, era considerada de natureza assistencial, somente as pré-escolas que funcionavam em escolas públicas ou privadas, possuíam caráter educacional.

A Constituição Federal em seu artigo 208, IV, prescreve: O dever do Estado com a educação será efetivado mediante a garantia de:IV - educação infantil, em creche e pré-escola, às crianças até 5(cinco) anos de idade; ( Redação dada pela Emenda Constitucional nำ53, de 2006) 
Com a Constituição de 1988, a criança é vista como um cidadão de direitos, a educação infantil passa a ser do ponto de vista legal, dever do estado e a creche é reconhecida como instituição educativa. Contudo, esta Lei educacional prevê os direitos, mas, não os detalha e nem organiza os aspectos gerais do ensino, o que justifica a relevância da Lei de Diretrizes e Bases da Educação Nacional (LDB) que trata especificamente do tema.

Sobre a educação Infantil, a LDB de 1996 no artigo 29 delibera:

\begin{abstract}
A educação infantil primeira etapa da educação básica tendo como objetivo o desenvolvimento integral da criança até os 6 anos de idade, em seus aspectos físicos, psicológicos, intelectual e social complementando a ação da família e da comunidade. (BRASIL, 1996).
\end{abstract}

Embora a Educação Infantil seja elencada na legislação, sem recursos financeiros, essa etapa esteve intencionada por boas intenções, antigamente não constavam no senso escolar, por não pertencer ao sistema de ensino e não eram cadastradas junto ao Ministério de Educação. Espera-se que esta realidade seja modificada a partir do momento em que passou a fazer parte da educação básica "[...] a inclusão da educação infantil no conceito de educação básica- primeira etapa, diz o texto legal- representa um avanço importante nas responsabilidades públicas sobre a educação. (CARNEIRO, 2012, p.218)"

Em se tratando de financiamento educacional, a Constituição Federal de 1988 delibera: "no mínimo 18\% da União e 25\% dos Estados, DF e Municípios da receita resultante de impostos, incluída a proveniente das transferências, para despesas com MDE, (art. 212)."

A Emenda Constitucional de 14 de setembro de 1996 preconiza: no mínimo $15 \%$ da receita resultante dos impostos devem ser investidos na manutenção e ampliação do ensino fundamental; o remanescente no máximo $10 \%$ da receita dos impostos deve ser destinado à educação infantil e/ou no ensino fundamental, ou seja, a educação infantil deve ser mantida com os recursos destinados à manutenção do ensino. Como desafio para Educação Infantil, o Plano Nacional de Educação indicou aos municípios a aplicação prioritária dos $10 \%$ dos recursos vinculados ao MDE não designados ao ensino fundamental (ABREU, 2004, p. 13).

Conforme a LDB (art. 11) é de responsabilidade dos Municípios a responsabilidade das instituições de educação infantil, municipais e privadas, pois, estas integram o Sistema Municipal de Ensino. Concluindo, este deve garantir prioridade do repasse de verbas ao ensino fundamental, depois 
educação infantil, e somente deverá destinar recursos a outras áreas do ensino, quando as necessidades destes segmentos forem atendidas.

Em cinco de abril de 2013, a LDB foi atualizada por meio da Lei no 12.796/2013 que obriga a matrícula de crianças a partir dos quatro anos na pré-escola e estabelece o ano de 2016 como prazo final para universalização.

\section{Embora no Brasil, a legislação e as políticas públicas de educação apontem caminho do modelo formal, institucional, escolar, ou seja, creches e pré-escolas ou centros de educação infantil, como regra geral de atendimento educacional às crianças pequenas, a universalização do modelo "escolar" está longe de ser alcançado. (ABREU, 2004, p.14)}

A partir do ano de 2016, a educação infantil deveria passar por uma avaliação do Instituto Nacional de Estudos e Pesquisas Educacionais Anísio Teixeira (Inep) denominado: Avaliação Nacional de Educação Infantil (Anei), nos quais seriam avaliadas seis dimensões: o acesso e a oferta por idade; a infraestrutura; os recursos pedagógicos; os profissionais de educação infantil; gestão do sistema de educação e gestão da escola. "Com a avaliação nacional, a educação infantil ganha mais relevo no debate educacional. A produção de indicadores nos ajuda ainda a travar o bom diálogo na busca por recursos", disse o diretor de Avaliação da Educação Básica do Inep, Alexandre André dos Santos.Essa proposta foi apresentada no dia dezessete de julho de 2015, no 15ำ Fórum Nacional dos Dirigentes Municipais de Educação, entretanto, não se efetivou.

Ao longo dos tempos, no Brasil, o que se observa é que na maioria das vezes as decisões da gestão pública são ineficazes para atender na necessidades educacionais apresentadas, principalmente no que se refere à educação infantil. Com esta iniciativa, partindo dos indicadores levantados, espera-se uma otimização da gestão no que se refere à tomada de decisões e o alcance dos metas previstas no PNE para a Educação Infantil e a excelência dos serviços prestados.

\section{CONSIDERAÇÕES FINAIS}

Partindo do exposto, podemos concluir que progressos têm ocorrido, nas políticas educacionais brasileiras, entretanto, estamos longe de cumprir com o que determina a Constituição Federal de 1988. Conforme preconiza a Constituição de 1988, no art. 3o, o principal propósito da Administração Pública é atingir os objetivos da República Federativa do Brasil:

I - construir uma sociedade livre, justa e solidária; II - garantir o desenvolvimento nacional;

III - erradicar a pobreza e a marginalização e reduzir as desigualdades sociais e regionais; 
IV - promover o bem de todos, sem preconceitos de origem, raça, sexo, cor, idade e quaisquer outras formas de discriminação. (CF de 1988 , art.3ํ).

No que diz respeito à educação, não podemos afirmar que todas as mazelas do país se resolverão com as questões educacionais, entretanto, sem negligenciar outros setores públicos, a educação deve estar no centro das decisões políticas de todos os gestores comprometidos, conforme assegura Barreto (2003).

A situação atual da educação infantil como politica publica no Brasil tem demonstrado avanços, entretanto, estudos recentes apontam a necessidade de um investimento maior devido sua importância. A UNICEF, UNESCO, Banco Mundial e IPEA tem realizado pesquisas no Brasil e no mundo sobre o resultado de ações dirigidas à criança pequena e contribuem com importantes reflexões. De acordo com estes estudos, a ampliação dos anos de permanência na escola, ou seja, o tempo de escolaridade interfere diretamente no tipo de emprego, no nível de renda familiar, na vida útil, no bem estar dos futuros adultos e de seus familiares. Os alunos que frequentam educação infantil, diminuem os índices de fracasso escolar, de natalidade, de pobreza, de criminalidade e de violência.

Constatamos que o investimento na educação infantil tem apresentado um resultado muito positivo e influenciado na diminuição das desigualdades sociais. Cabe aos gestores, de todas as esferas criar condições propícias que favoreçam a concretização de políticas educacionais eficientes. À Federação cabe criar uma estrutura financeira e administrativa que permita a efetivação de políticas voltadas para a educação infantil, aos Municípios, garantir o atendimento, e aos Estados e à União dar o suporte necessário para sua concretização, visto que tem sido tímida sua participação nesta área. Vale ressaltar a importância de se integrar empreendimentos das três esferas governamentais, e incentivar a participação coletiva na análise, das necessidades, nas decisões e execução do planejamento.

Através de uma gestão comprometida com fortalecimento da cidadania e investimentos na educação, podemos melhorar a qualidade de vida dos cidadãos brasileiros.

\section{REFERÊNCIAS}

ABREU Mariza. Educação Infantil no Brasil: legislação, matrículas, financiamento e desafios. Brasília. DF: Câmara dos Deputados. 2004. 
BARRETO, Ângela Maria Rabelo Ferreira. A educação infantil no contexto das políticas públicas. Revista Brasileira de Educação, Rio de Janeiro, n. 24, set./dez. 2003

BRASIL. Constituição (1988). Constituição da República Federativa do Brasil. São Paulo: Ed. Revista dos Tribunais, 1989.

Senado Federal. Lei de Diretrizes e Bases da Educação Nacional: no 4024/61. Brasília: 1961.

. Senado Federal. Lei de Diretrizes e Bases da Educação Nacional: no 5692/71. Brasília: 1971.

. Senado Federal. Lei de Diretrizes e Bases da Educação Nacional: no 9394/96. Brasília: 1996.

. Senado Federal. Lei de Diretrizes e Bases da Educação Nacional: no 12796/2013. Brasília: 2013

. Plano Nacional de Educação. 2001 disponível em <

http://portal.mec.gov.br/arquivos/pdf/pne.pdf> Acessado em 18/06/2015

CARNEIRO, Moacir Alves. LDB Fácil: leitura crítico- compreensiva artigo a artigo.20.ed. Petrópolis,RJ:Vozes, 2012

DELORS, Jacques et all. Educação: um tesouro a descobrir- Relatório para a UNESCO da Comissão Internacional sobre Educação para o século XXI. 7 ed. São Paulo: Cortez; Brasília, DF: MEC: UNESCO,2012

PAULA, Ana Paula Paes. Administração Pública Brasileira entre o Gerencialismo e a Gestão Social. Revista de Administração de Empresas. 45(1), janeiro/março de 2005

PEREIRA, Luiz Carlos Bresser. In Bresser-Pereira e Spink, orgs. (1998) Reforma do Estado e Administração Pública Gerencial. Revista do Serviço Público, 47(1) janeiro1996. Disponível em:

http://www.bresserpereira.org.br/papers/1996/95.admpublicaburocraticaageren cial.pdf> Acessado em 30/07/2019

SAVIANI, Demerval. Educação brasileira: Estrutura e sistema. $7^{a}$ ed., Campinas: Autores Associados, 1996.

WCEFA - CONFERÊNCIA MUNDIAL DE EDUCAÇÃO PARA TODOS. Declaração mundial sobre educação para todos e Plano de ação para satisfazer as necessidades Básicas de aprendizagem. Jomtien, Tailândia: março de 1990. Disponível emhttp://unesdoc.unesco.org/images/0008/000862/086291 por.pdf acessado em 20/06/2019. 


\title{
MONITORAMENTO E AVALIAÇÃO DE PLANOS MUNICIPAIS DE EDUCAÇÃO: Uma análise dos documentos orientadores nacionais
}

\author{
MILITÃO, Silvio Cesar Nunes \\ Doutor em Educação - UNESP \\ scnmilitao@gmail.com \\ ARANDA, Maria Alice de Miranda \\ Doutora em Educação - UFMS \\ mariaalicearanda@gmail.com
}

\section{INTRODUÇÃO}

Após praticamente quatro anos de tramitação no Congresso Nacional, foi aprovado pela Lei no 13.005/2014 o Plano Nacional de Educação (PNE) para o decênio 2014-2024, composto por 14 Artigos, 20 Metas e 254 Estratégias voltadas a todos os níveis, etapas e modalidades de ensino. Com o advento da referida Lei, as questões relativas ao monitoramento e avaliação dos planos educacionais ganharam notável destaque (BONAMINO; CARVALHO; WALDHELM; CRUZ, 2014).

Este trabalho é parte constituinte de pesquisa mais ampla intitulada "Monitoramento do Planos Decenais de Educação na Região Administrativa de Marília (SP)", voltada ao mapeamento e análise dos mecanismos de implementação, monitoramento e avaliação dos Planos Municipais de Educação (PMEs) jurisdicionados à Região supracitada, desenvolvida em nível de pós-doutoramento junto ao Programa de PósGraduação em Educação da Universidade Federal da Grande Dourados (PPGEdu/UFGD), financiada pelo Programa Nacional de Pós-Doutorado (PNPD/CAPES).

O presente trabalho objetiva, particularmente, analisar quais são as principais orientações e procedimentos emanados pelo conjunto de documentos produzidos pela Secretaria de Articulação com os Sistemas de Ensino (SASE) do Ministério da Educação (MEC) para auxiliar tecnicamente os municípios brasileiros no processo de monitoramento e avaliação dos seus respectivos Planos Municipais de Educação (PMEs), bem como cotejá-los com a literatura acadêmica correlata no intuito de desvelar similitudes e diferenças. 


\title{
2. METODOLOGIA
}

Tendo em vista a consecução do objetivo proposto, o trabalho desenvolvido ancorou-se em uma abordagem qualitativa e contemplou os seguintes procedimentos metodológicos: pesquisa bibliográfica e documental.

Primeiro passo de toda pesquisa científica, a pesquisa bibliográfica foi inicialmente realizada, propiciando a identificação da literatura acadêmica correlata à temática em abordagem e, fundamentalmente, subsidiando a construção do referencial teórico do presente trabalho. Segundo esclarecem Marconi e Lakatos (2011, p. 43), trata-se do "[...] levantamento de toda a bibliografia já publicada, em forma de livros, revistas, publicações avulsas e imprensa escrita. Sua finalidade é colocar o pesquisador em contato direto com tudo aquilo que foi escrito sobre determinado assunto".

Posteriormente, a pesquisa documental foi desenvolvida. $\mathrm{Na}$ precisa explicação de Gil (1999, p. 66):

\begin{abstract}
A pesquisa documental assemelha-se muito a pesquisa bibliográfica. A única diferença entre ambas está na natureza das fontes. Enquanto a pesquisa bibliográfica se utiliza fundamentalmente das contribuições dos diversos autores sobre determinado assunto, a pesquisa documental vale-se de materiais que não receberam ainda tratamento analítico, ou que ainda podem ser reelaborados de acordo com os objetivos da pesquisa. O desenvolvimento da pesquisa documental segue os mesmos passos da pesquisa bibliográfica. Apenas há que se considerar que o primeiro passo consiste na exploração das fontes documentais, que são em grande número. Existem, de um lado, os documentos de primeira mão, que não receberam qualquer tratamento analítico, tais como: documentos oficiais, reportagens de jornal, cartas, contratos, diários, filmes, fotografias, gravações etc. De outro lado, existem os documentos de segunda mão, que de alguma forma já forma analisados, tais como: relatórios de pesquisa, relatórios de empresas, tabelas estatísticas.
\end{abstract}

Sem dúvida, a pesquisa documental constitui-se em uma técnica importante na pesquisa qualitativa, seja complementando informações obtidas por outras técnicas, seja desvelando aspectos novos de um tema ou problema. (LUDKE; ANDRÉ, 1986).

Assim, a pesquisa documental contemplou como corpus de análise os seguintes documentos federais: PNE 2014-2024 (2014); Planejando a próxima década: alinhando os planos de educação (2014); Caderno de Orientações para elaboração dos PMEs (2014); e Cadernos de Orientações para o monitoramento e avaliação dos PMEs (2016).

Tais documentos foram coletados diretamente na página1 do Ministério da Educação (MEC) denominada "PNE em Movimento", na aba "Publicações", a qual reúne todos os documentos produzidos pela Secretaria de Articulação com os Sistemas de Ensino (SASE) do MEC para auxiliar

\footnotetext{
${ }^{1}$ Trata-se da página criada pelo MEC para acompanhar a situação dos Planos de Educação do país, disponível em: <http://pne.mec.gov.br> e acessada em 10/07/2019.
} 
tecnicamente os entes federativos brasileiros no processo de elaboração e/ou adequação, monitoramento e avaliação dos seus respectivos Planos de Educação, disponíveis livre e gratuitamente para consulta e download por qualquer interessado.

\section{DESENVOLVIMENTO}

Alçados à condição de entes federativos autônomos somente a partir da Constituição Federal de 1988 (CF/1988), os municípios brasileiros deparam-se ainda com sérias adversidades para exercerem tal autonomia e consequentemente responsabilizar-se pela formulação, implementação e gestão das políticas públicas em consonância com as demandas da realidade local.

Arelaro $(2015$, p. 32) sintetiza bem a fragilidade e dependência financeira das municipalidades brasileiras que obstaculizam sobremaneira a efetivação das políticas sociais no âmbito local:

Cerca de $70 \%$ dos 5570 municípios podem ser considerados pobres e muito pobres, por serem pequenos (não atingem 20 000 habitantes) e não conseguirem arrecadar recursos próprios, proporcionais às suas necessidades de implantação dos direitos sociais básicos, e, portanto, dependem da redistribuição de recursos da União.

No caso da educação, em particular, após o advento da CF/1988 - posteriormente ratificada e regulamentada pela Lei de Diretrizes e Bases da Educação Nacional №. 9.394/96 (LDB/96) - as esferas municipais passam a poder criar sistemas municipais de ensino próprios e a desempenhar relevante e crescente papel no campo educacional.

Nas palavras de Gentilini (2012, p. 55):

A descentralização da gestão da educação no Brasil transformou os municípios em atores estratégicos na implementação das políticas e planos educacionais no Brasil, a partir de novas e mais complexas responsabilidades na formulação e gestão de políticas públicas. Os municípios passaram a ter responsabilidades significativamente maiores $\mathrm{e}$ mais complexas do que tinham até então e não foram poucos os casos em que se viram despreparados para assumi-las, depois de mais de duas décadas em que as políticas públicas eram formuladas na esfera federal [...].

Apesar do empenho e luta da instância municipal para desempenhar as funções que lhes cabe em termos educacionais, não se pode desconsiderar "a pluralidade e assimetria dos municípios que carecem de estruturas materiais, físicas, humanas, financeiras, administrativas e 
pedagógicas para implantar políticas educacionais e dar continuidade a elas" (OLIVEIRA et al, 2006, p. 40).

Responsáveis majoritários pela oferta da educação infantil e do ensino fundamental na atualidade, cada vez mais os municípios brasileiros se veem obrigados a planejar os rumos da educação na sua área jurisdicional, cujo Plano Municipal de Educação (PME) constitui instrumento de suma importância nesta empreitada.

Como instrumento de operacionalização do sistema, o PME define a concepção e viabiliza a realização do projeto municipal de educação, superando rotinas, ações segmentadas e improvisações. [...] O plano municipal de educação é o instrumento de gestão para tornar efetiva a cidadania e a sociedade preconizada nas bases e diretrizes do Sistema Municipal de Educação (BORDIGNON, 2009, p.93).

Mas, diante da inexistência no país de uma larga tradição de planejamento educacional local, bem como pela aludida assimetria dos 5570 municípios brasileiros, somente tardiamente o Brasil atinge uma inédita (quase) universalização2 dos PMEs.

Conforme a "[...] experiência brasileira mostra, se não é fácil aprovar um plano de educação, mais difícil ainda é garantir sua implantação de forma efetiva" (PINTO, 2017, p. 17).

Assim, uma vez elaborados e aprovados os planos educacionais infranacionais, "[...] desafio maior ainda será o processo de implementação, monitoramento e avaliação destes planos [...]" (NASCIMENTO; GROSSI JÚNIOR; PEREIRA, 2017, p. 125).

Considerando que "a ausência de monitoramento e avaliação [...] afeta bastante a realização da própria política e, consequentemente, seus resultados" (PARENTE; PEREZ; MATTOS, 2011, p. 26), a Lei no 13.005/2014 instituidora PNE 2014-2024 foi além do PNE precedente (2001-2010) e avançou ao definir com maior precisão as instâncias responsáveis pela realização de tal processo em âmbito federal. Textualmente:

Art. 5ํ A execução do PNE e o cumprimento de suas metas serão objeto de monitoramento contínuo e de avaliações periódicas, realizados pelas seguintes instâncias:

I - Ministério da Educação - MEC;

II - Comissão de Educação da Câmara dos Deputados e Comissão de Educação, Cultura e Esporte do Senado Federal; III - Conselho Nacional de Educação - CNE;

2 Conforme informações disponibilizadas pela página do MEC denominada "PNE em Movimento - Situação dos Planos de Educação", visitada em 10/07/2019, dos 5.570 municípios brasileiros, enquanto 5.568 (ou 99,96\%) deles já aprovaram seus respectivos PMEs na forma da Lei, somente 2 (ou 0,04\%) ainda não o fizeram (laras e Ribeirão Preto, ambos do estado de São Paulo). 
IV - Fórum Nacional de Educação (BRASIL, 2014a).

Após atribuir a um conjunto de distintos e importantes atores institucionais a responsabilidade pelo monitoramento e avalição do plano federal, a Lei do PNE determina também que todos os entes federados deverão proceder de forma semelhante em relação aos seus respectivos planos subnacionais. Na letra da lei:

Art. $7^{\circ}$ A União, os Estados, o Distrito Federal e os Municípios atuarão em regime de colaboração, visando ao alcance das metas e à implementação das estratégias objeto deste Plano.

[...]

$\S 3^{\circ}$ Os sistemas de ensino dos Estados, do Distrito Federal e dos Municípios criarão mecanismos para o acompanhamento local da consecução das metas deste PNE e dos planos previstos no art. 8으 (BRASIL, 2014a).

Assim, de forma análoga a lei do PNE, os planos infranacionais de educação, além de prever sistemáticas de monitoramento e avaliação dos referidos documentos, devem também definir expressamente quais serão os atores institucionais encarregados desta imperiosa tarefa. Nesse sentido, Oliveira et al (2016, p. 31, grifos do autor) elencam as instâncias mais indicadas para tal incumbência em âmbito local:

[...] Nos municípios:

- Secretaria Municipal de Educação;

- Comissão de Educação da Câmara ou a própria Câmara;

- Conselho Municipal de Educação;

- Fórum Municipal de Educação.

A díspar e adversa realidade municipal no Brasil justifica, portanto, "[...] a necessidade de uma ação indutora do MEC para instituir ações de assessoramento para que os municípios possam [...]" (CABRAL NETO; CASTRO; GARCIA, 2016, p. 55) efetivamente monitorar e avaliar a implementação dos seus PMEs.

Nesse sentido, o Governo Federal - resgatando o papel supletivo da União na área educacional preconizado pela CF/1988 - criou em 20113 na estrutura do MEC a SASE, órgão inicialmente responsável pela articulação entre os planos de educação e pela promoção de assistência técnica aos entes federativos relativa ao processo de elaboração dos referidos documentos decenais.

Dourado, Grossi Júnior e Furtado (2016, p. 453) destacam que o supramencionado "[...] apoio técnico da União, por meio da SASE/MEC, foi de

\footnotetext{
${ }^{3}$ Criada no Governo de Dilma Rousseff, mediante o Decreto № 7.480, de 16 de maio de 2011, a SASE foi extinta no corrente ano pelo governo Jair Bolsonaro, através do Decreto no 9.465, de 02/01/2019.
} 
grande valia para o processo de formulação ou adequação dos planos estaduais, Distrital e municipais, sobretudo se considerarmos as assimetrias entre os entes federados", concorrendo inclusive chegar-se a tão almejada articulação dos mesmos.

Conforme destaca Monlevade (2012, p. 93), tais "[...] planos devem ser articulados um com o outro. Nós não podemos fazer um Plano Municipal sem dialogar com o estado e muito menos sem dialogar com 0 governo federal".

Após assessorar o correspondente processo de elaboração dos referidos documentos decenais, a SASE/MEC deu continuidade a partir de 2015 ao trabalho de apoio aos entes federativos mediante construção e disponibilização - via adesão4 - de metodologia voltada à sistematização e realização de processos de monitoramento e avaliação de tais planos.

Assim, na página PNE em Movimento", na aba "Publicações", está acessível para todos os entes federativos e demais interessados um conjunto de documentos orientadores editados pela SASE/MEC na forma de manuais, voltados à finalidade supracitada.

Tendo em vista subsidiar o processo de elaboração ou adequação dos PMEs, a SASE/MEC publicou em 2014, logo na sequência da aprovação do PNE 2014-2024, o documento intitulado "O Plano Municipal de Educação: caderno de orientações", o qual, além de reforçar a importância da aprovação dos PMEs articulados ao novo PNE e alinhados aos PEEs, elencou como um dos aspectos indispensáveis a constar no documento de planejamento local da educação:

Um conjunto de indicadores com os responsáveis pelo seu monitoramento e avaliação, de tal maneira que não se deixe para avaliar os resultados do Plano no final da década. Assim, é indispensável definir de quem será essa atribuição e qual será a sua periodicidade. Uma ação compartilhada entre a Secretaria Municipal, a Comissão ou Conselho e Fórum Municipal de Educação, onde houve, e a Câmara de Vereadores pode ser uma sugestão a ser

${ }^{4}$ Conforme informações disponibilizadas pela página do MEC denominada "PNE em Movimento - Monitoramento e Avaliação dos Planos Subnacionais de Educação", visitada em 10/07/2019, das 27 unidades da Federação, incluindose o Distrito Federal, em 25 (ou 92,6\%) delas e em 5.517 (ou 99,05\%) dos 5.570 municípios brasileiros registra-se adesão à referida rede. Em contrapartida, em apenas dois (ou 7,4\%) estados (Minas Gerais e Rio de Janeiro) e em 53 (ou 0,95\%) municípios (sendo: 1 da Bahia, 1 do Espírito Santo, 25 de Minas Gerais e 26 de São Paulo) não se verifica tal adesão. 
considerada. Para o sucesso dessa tarefa, os responsáveis pelo monitoramento (que pode ser anual) e avaliação (que pode ser trienal), precisam dispor de indicadores bem elaborados e aprovados junto com o PME; tais dispositivos, assim previstos, ajudarão inclusive o monitoramento do PEE e do PNE. Além de serem ferramentas indispensáveis para o processo de monitoramento e avaliação, os indicadores permitem a comunicação com a sociedade, assegurando a transparência e o controle social do Plano. Por essa razão, devem ser objetivos, mensuráveis no tempo, factíveis e relevantes. Aos responsáveis pelo monitoramento e avaliação também pode ser atribuída a tarefa de promover Conferências Municipais de Educação, que fornecerão insumos para analisar a execução do Plano e, consequentemente, subsidiar a elaboração de um novo plano para o decênio subsequente (BRASIL, 2014b. p. 11).

Ainda segundo o documento supracitados, tanto a periodicidade quanto a forma de monitoramento e avaliação do PME devem constar no próprio da lei, "[...] ficando o detalhamento das metas e estratégias do PMR no seu anexo", sugerindo, ainda, na sequência, que "a definição de um período de avaliação similar ao do projetados para o PNE pode ser a melhor alternativa" (BRASIL, 2014b. p. 12).

Para o êxito do processo de monitoramento e avaliação da execução do PME, é fundamental que se discuta e se defina "[...] a responsabilidade do Poder Executivo, da Câmara de Vereadores, do Fórum, do Conselho de Educação (onde estiverem instituídos) ou Comissão em relação[...] ao processo em tela (BRASIL, 2014b. p. 17).

Cumpre registrar que para Monlevade (2004, p 43) o papel central na tarefa de monitoramento contínuo e avaliação periódica do PME deve ser exercido pelo Conselho Municipal de Educação (CME). Textualmente:

\footnotetext{
É fundamental que, concluída a tramitação e aprovada a lei do PME, se constitua um fórum permanente para seu acompanhamento e avaliação. Nos municípios onde existe um CME bem representativo e estruturado, com alguma autonomia financeira (ser unidade orçamentária, com dotação, por exemplo, correspondente a $1 \%$ dos recursos vinculados à manutenção e ao desenvolvimento do ensino), ousaria dizer que esse fórum deve ser o próprio Conselho.
}

Um outro documento publicado pela SASE/MEC também em 2014 destinado ao auxílio dos municípios no tocante à elaboração ou adequação dos PMEs denomina-se "Planejando a próxima década: alinhando os Planos de Educação", o qual faz apenas um ligeira menção a respeito do processo de monitoramento e avalição dos planos subnacionais na breve seção, assim nomeada: "C) Monitoramento e Avaliação".

De modo similar ao previsto para o Plano federal, preconiza-se:

Os planos estaduais, distrital e municipais devem prever processos e procedimentos semelhantes de acompanhamento e avaliação, portanto, devem prever e determinar estruturas, 
processos, mecanismos e momentos estratégicos para a realização das avaliações, explicitando mecanismos para analisar indicadores e resultados alcançados, com o objetivo de redirecionar as estratégias e as ações de execução (BRASIL, 2014c. p. 17).

O último do documento da tríade analisada é o "PNE em Movimento: Cadernos de Orientações para o monitoramento e avaliação dos Planos Municipais de Educação, lançado em 2016 e, como o próprio título denota, trata-se do principal documento editado pela SASE/MEC para nortear tal processo pelas esferas locais.

Numa espécie de passo-a-passo, primeiramente o Caderno apresentação uma distinção entre os dois termos envolvidos:

O monitoramento [é] um ato contínuo de observação pelo qual são tornadas públicas as informações a respeito do progresso que vai sendo feito para 0 alcance das metas definidas.

A avaliação [é] o ato periódico de dar valor aos resultados alcançados até aquele momento, às ações que estejam em andamento e àquelas que não tenham sido realizadas, para determinar até que ponto os objetivos estão sendo atingidos e para orientar a tomada de decisões (BRASIL, 2016, p. 6, grifos nossos).

Depreende-se, então, que monitorar e avaliar são etapas que se articulam mutuamente durante o processo de implementação de um plano de educação, pois "[...] não é possível o monitoramento sem que, periodicamente, ocorram avaliações. De igual forma, não convém avaliar sem que haja informações obtidas a partir do monitoramento contínuo do que foi proposto por meio de indicadores adequados" (DOURADO; GROSSI JÚNIOR; FURTADO, 2016, p. 457-458).

O documento supracitado destaca que as instâncias responsáveis pelo monitoramento e avaliação devem ser aquelas definidas no PME aprovado. Entretanto,

Caso o município não tenha definido a quais instâncias cabe o papel de monitorar e avaliar o plano, a sugestão é que a secretaria de educação considere os integrantes da comissão coordenadora que organizou o processo de elaboração ou adequação do plano aprovado e a equipe técnica que a assessorou, de forma a qualificar o processo, considerando o acúmulo de conhecimentos e as articulações institucionais já estabelecidas (BRASIL, 2016, p. 7).

O caderno de orientações sugere, ainda,

[...] que a Secretaria de Educação constitua uma equipe técnica para atuar no levantamento e na sistematização de todos os dados e informações referentes ao plano. Não se trata 
de uma instância obrigatória na consecução das ações de monitoramento e avaliação, no entanto, o apoio técnico dessa equipe contribuirá para que a comissão possa desencadear suas proposições, respaldada em fontes oficiais e em sintonia com o Poder Executivo (BRASIL, 2016, p. 7).

Entende-se que, ainda que não compulsória, a equipe técnica confira-se de suma importância, tanto para respaldar 0 processo de monitoramento e avaliação do PME, quanto para não sobrecarregar a Comissão Coordenadora do processo na laboriosa tarefa de busca de dados de ordem mais técnica.

Vale destacar, também, que o documento é enfático ao assinalar que, "independentemente da situação posta no município, torna-se necessário que o [CME] e o Fórum Municipal de Educação (FME) sejam partícipes da comissão, contribuindo assim com a mobilização e a participação social no processo" BRASIL, 2016, p. 7).

A metodologia do processo de monitoramento e avaliação proposta pelo Caderno de Orientações ancora-se no preenchimento de uma Ficha. Portanto,

A sugestão é que a equipe técnica utilize a Ficha de Monitoramento do Plano Municipal de Educação, que está organizada em três partes, cada uma correspondente às etapas de trabalho propostas: organizar o trabalho; estudar o plano; e monitorar continuamente as metas e estratégias (BRASIL, 2016, p. 7).

Uma vez preenchidas todas as partes da ficha, a equipe responsável

[...] deverá elaborar um documento e enviar para a Secretaria Municipal de Educação. De posse desse documento avaliativo a Secretaria deverá promover um debate público sobre os resultados parciais do PME, envolvendo sociedade civil, poder legislativo e executivo (ANTUNES, 2019, p. 26).

Da avaliação final do Plano, poderão decorrer "[...] recomendações para a alteração da lei do PME” (BRASIL, 2016, p. 14). Porém, "[...] se forem feitas proposta de alteração do plano, um projeto de lei deverá ser encaminhado pelo Poder Executivo à câmara de vereadores" (BRASIL, 2016, p. 11).

\section{CONSIDERAÇÕES FINAIS}


Das análises realizadas, a partir do exame e cotejamento das fontes documentais selecionadas e à luz da literatura concernente à temática, depreende-se que o Governo Federal centralizou nas suas mãos o poder de decisão sobre a concepção e metodologia atinentes ao processo de monitoramento e avaliação dos PMEs, reservando aos antes federativos locais um papel de coadjuvante no referido processo, pautado pelo desenvolvimento de ações de viés mais operacional.

\section{REFERÊNCIAS}

ANTUNES, Marina Ferreira de Souza. Plano Municipal de Educação de Uberlândia - monitoramento e avaliação: desafios para a valorização da carreira docente. Revista Educação e Políticas em Debate, v. 8, n. 1, p. 19-36, jan./abr. 2019.

ARELARO, Lisete Regina Gomes. É possível implantar, em curto prazo, um sistema nacional de educação no Brasil? In: CALDAS, Andréa (Org.). O plano nacional de Educação e o sistema nacional de educação. Curitiba, 2015, p. 3150.

BONAMINO, Alícia; CARVALHO, Cynthia Paes de; WALDHELM, Andrea Paula de Souza; CRUZ, Larissa Frossard Rangel. Lugar e papel da avaliação em planos municipais de educação: uma análise do processo de planejamento educacional. In: SOUZA, Donaldo Bello de; MARTINS, Angela Maria (Orgs.). Planos de Educação no Brasil: planejamento, políticas, práticas. São Paulo: Edições Loyola, 2014. p. 303-328.

BORDIGNON, Genuíno. Gestão da educação no município: sistema, conselho e plano. São Paulo: Editora e Livraria Instituto Paulo Freire, 2009.

. Caminhar da educação brasileira: muitos planos, pouco planejamento. In: SOUZA, Donaldo Bello de; MARTINS, Angela Maria (Orgs.). Planos de Educação no Brasil: planejamento, políticas, práticas. São Paulo: Edições Loyola, 2014. p. 29-53.

BRASIL. Constituição da República Federativa do Brasil, 1988. Brasília: Senado Federal, Centro Gráfico, 1988.

. Lei no 9.394, de 20 de dezembro de 1996. Dispõe sobre as Diretrizes e Bases da Educação Nacional. Brasília: 1996. 
. Lei no 13.005, de 25 de junho de 2014. Aprova o Plano Nacional de Educação e dá outras providências. Diário Oficial da União, Brasília, DF, 26. jun. 2014. Seção 1, p.01. 2014a.

Ministério da Educação. Secretaria de Articulação com os Sistemas de Ensino (SASE). O Plano Municipal de Educação: caderno de orientações. Brasília: MEC, 2014b.

- Ministério da Educação. Secretaria de Articulação com os Sistemas de Ensino (SASE). Planejando a próxima década: alinhando os planos de educação. Brasília: MEC, 2014c.

- Ministério da Educação. Secretaria de Articulação com os Sistemas de Ensino (SASE). Caderno de Orientações para Monitoramento e Avaliação dos Planos Municipais de Educação. Brasília: MEC, 2016.

CABRAL NETO, Antônio; CASTRO, Alda Maria Duarte Araujo; Garcia, Luciane Terra dos Santos. Plano Municipal de Educação: elaboração, acompanhamento e avaliação no contexto do PSR. RBPAE, v. 32, n. 1, p. 4767, jan./abr.. 2016.

DOURADO, Luiz Fernandes; GROSSI JUNIOR, Geraldo; FURTADO, Roberval Ângelo. Monitoramento e avaliação dos planos de educação: breves contribuições. RBPAE, v. 32, n. 2, p. 449 - 461 mai./ago. 2016.

GIL, Antonio Carlos. Métodos e técnicas de pesquisa social. São Paulo: Atlas, 1999.

MARCONI, Marina de Andrade; LAKATOS, Eva Maria. Metodologia do trabalho científico: procedimentos básicos, pesquisa bibliográfica, projeto e relatório, publicações e trabalhos científicos. 7. ed. 6. reimpr. São Paulo: Atlas, 2011.

MONLEVADE, João Antônio. A importância do Conselho Municipal de Educação na elaboração, implantação e acompanhamento da execução do Plano Municipal de Educação. In: BRASIL. Ministério da Educação. Secretaria de Educação Básica. Programa Nacional de Capacitação de Conselheiros Municipais de Educação Pró-Conselho: caderno de referência. Brasília, DF: MEC/SEB, 2004.

NASCIMENTO, Gilvânia da Conceição; GROSSI JUNIOR, Geraldo; PEREIRA, Jhonata Moreira. Planos Municipais de Educação: perfil dos municípios que não possuíam plano municipal de educação no segundo ano de vigência da Lei 
n. 13.005/14. Revista Exitus, Santarém/PA, Vol. 7, n. 1, p. 108-130, jan./abr. 2017.

OLIVEIRA, Cleiton de et al. Conselhos Municipais de Educação: um estudo na região metropolitana de Campinas. Campinas, SP: Alínea, 2006.

PARENTE, Cláudia da Mota Darós; PEREZ, José Roberto Rus; MATTOS, Maria José Viana Marinho de. Avaliação, monitoramento e controle social: contribuição à pesquisa e à política educacional. In: PARENTE, Cláudia da Mota Darós; PARENTE, Juliano Mota (Orgs.). Avaliação, política e gestão da educação. São Cristóvão: Editora UFS, 2011. p. 15-31.

PINTO, J. M. de R. Prefácio. In: MILITÃO, A. N.; PERBONI, F. (Orgs.). Plano Nacional de Educação: diversos olhares. Curitiba: CRV, 2017, p. 17-18. 


\title{
O LUGAR DO MONITORAMENTO E AVALIAÇÃO NOS PLANOS MUNICIPAIS DE EDUCAÇÃO: O caso da Região Administrativa de Marília/SP
}

\author{
MILITÃO, Silvio Cesar Nunes \\ Doutor em Educação - UNESP \\ scnmilitao@gmail.com \\ ARANDA, Maria Alice de Miranda \\ Doutora em Educação - UFMS \\ mariaalicearanda@gmail.com
}

\section{INTRODUÇÃO}

A Lei ำ 13.005/2014, que instituiu o Plano Nacional de Educação (PNE) vigente, determinou em seu artigo $8^{\circ}$ que todos os entes federativos subnacionais elaborassem seus respectivos Planos de Educação no prazo de um ano a partir da sua publicação (ou seja, até o dia 24 de junho de 2015), resultando numa inédita (quase) universalização dos planos educacionais infranacionais (ALVES, 2017; OLIVEIRA et al, 2016).

Conforme informações disponibilizadas pela página5 do Ministério da Educação (MEC) denominada "PNE em Movimento - Situação dos Planos de Educação", das 27 unidades da Federação, incluindo-se o Distrito Federal, 26 (ou 96,3\%) possuem Planos de Educação sancionados por lei e apenas um (ou 3,7\%) único estado (Rio de Janeiro) ainda não converteu seu correspondente plano em norma jurídica. Dos 5.570 municípios brasileiros, enquanto 5.568 (ou 99,96\%) deles já aprovaram seus respectivos Planos na forma da Lei, somente 2 (ou 0,04\%) ainda não o fizeram (laras e Ribeirão Preto, ambos do estado de São Paulo).

No caso do estado de São Paulo6, especificamente, dos 645 municípios integrantes: 643 (ou 99,7\%) já possuem Planos Municipais de Educação (PMEs) aprovados por lei municipal, enquanto que em outros 2 (ou $0,3 \%$ ) o Projeto de Lei referente ao respectivo PME encontra-se no Poder Legislativo local aguardando aprovação.

Diante de tal cenário, estados, Distrito Federal e municípios deparam-se, na atualidade, com o crucial desafio de implementar, monitorar e avaliar tais planos, tal qual demandado pelos artigos $5^{\circ}$ e $7^{\circ}$ da Lei $n^{\circ}$

\footnotetext{
${ }^{5}$ Trata-se da página criada pelo MEC para acompanhar a situação dos Planos de Educação do país, disponível em: <http://pne.mec.gov.br/planos-de-educacao/situacao-dos-planos-deeducacao > e acessada em 10/07/2019.

${ }^{6}$ Em São Paulo, o Plano Estadual de Educação foi aprovado pela Lei oㅡ 16.279, de 8 de julho de 2016, contendo 11 artigos, 21 metas e 262 estratégias.
} 
13.005/2014 (ANTUNES, 2019; DOURADO; GROSSI JÚNIOR; FURTADO, 2016; NASCIMENTO; GROSSI JÚNIOR; PEREIRA, 2017; SCAFF; OLIVEIRA, 2018).

Fruto de uma pesquisa mais ampla desenvolvida em nível de pósdoutoramento - financiada pelo Programa Nacional de Pós-Doutorado (PNPD/CAPES) -, o presente trabalho tem por objetivo precípuo analisar se/como as ações atinentes ao monitoramento e avaliação estão previstas nos Planos Municipais de Educação (PMEs) das municipalidades jurisdicionadas à Região Administrativa de Marília.

Localizada geograficamente no centro-oeste do Estado de São Paulo, a referida Região abriga 51 municípios (figura 1), a saber: Álvaro de Carvalho, Alvinlândia, Arco Íris, Assis, Bastos, Bernardino de Campos, Borá, Campos Novos Paulista, Cândido Mota, Canitar, Chavantes, Cruzália, Echaporã, Espírito Santo do Turvo, Fernão, Florínia, Gália, Garça, Herculândia, lacri, Ibirarema, Ipaussu, João Ramalho, Júlio Mesquita, Lupércio, Lutécia, Maracaí, Marília, Ocauçu, Óleo, Oriente, Oscar Bressane, Ourinhos, Palmital, Paraguaçu Paulista, Parapuã, Pedrinhas Paulista, Platina, Pompéia, Quatá, Queiroz, Quintana, Ribeirão do Sul, Rinópolis, Salto Grande, Santa Cruz do Rio Pardo, São Pedro do Turvo, Tarumã, Timburi, Tupã e Vera Cruz.

Na Região Administrativa de Marília, particularmente, a totalidade dos seus 51 municípios integrantes já aprovaram e possuem em vigência seus correspondentes PMEs, em consonância com o PNE 2014-2024.

Figura 1 - Localização e composição da Região Administrativa de Marilia

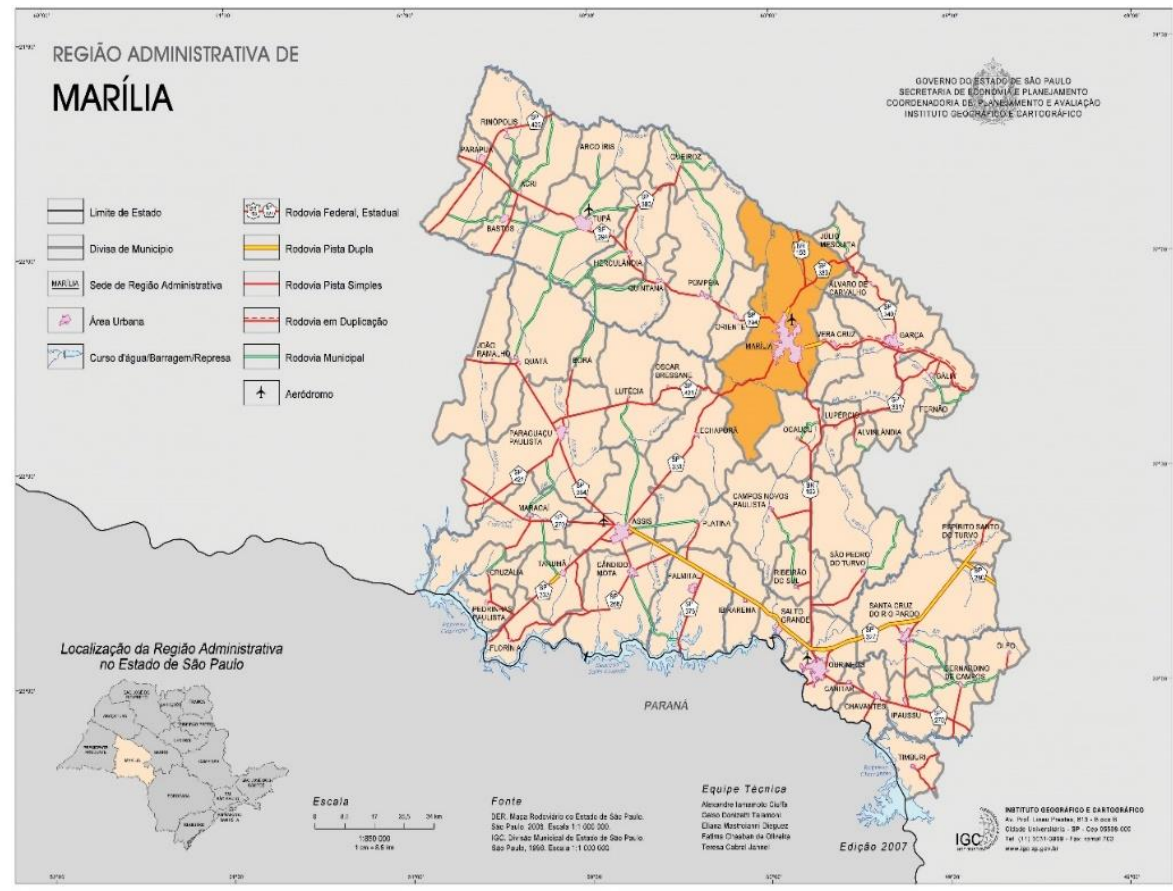


Fonte: Instituto Geográfico e Cartográfico - IGC. Disponível em $<$ http://www.igc.sp.gov.br/produtos/mapas_ra.aspx? >. Acesso em: $13 \mathrm{fev}$. 2019.

\section{METODOLOGIA}

Tendo em vista a consecução do objetivo proposto, o trabalho desenvolvido ancorou-se em uma abordagem qualitativa e contemplou os seguintes procedimentos metodológicos: pesquisa bibliográfica e documental.

Inicialmente realizada, a pesquisa bibliográfica consistiu no levantamento e análise "[...] de toda a bibliografia já publicada [...]" (MARCONI; LAKATOS, 2011, p. 43) acerca da temática em abordagem, propiciando a construção do referencial teórico da pesquisa e subsidiando a posterior e concernente análise dos dados empíricos coletados.

$\mathrm{Na}$ sequência, foi desenvolvida a pesquisa documental cujo corpus de análise abrangeu primordialmente os Planos de Educação de municípios pertencentes à Região Administrativa de Marília, além de dois documentos de âmbito federal: PNE 2014-2024 e Caderno de Orientações para elaboração dos PMEs.

Para coleta das leis de criação e correspondentes anexos (planos propriamente ditos, com as respectivas metas e estratégias fixadas) dos PMEs das municipalidades abrangidas pela região selecionada pelo estudo em tela, recorreu-se primeiramente a já referida página "PNE em Movimento - Situação dos Planos de Educação", na qual obteve-se acesso a 29 PMEs completos (dueto lei e anexo).7

Portanto, na sequência, realizou-se consultas por meio da internet aos sites das respectivas Câmaras Municipais, Prefeituras e Secretarias Municipais de Educação (ou órgão equivalente) para obtenção de mais PMEs completos, o que resultou em 35 planos coletados.

Adicionalmente, como nem todas as cidades mantinham disponíveis pública e eletronicamente (na internet) seus PMEs para consulta/download, fez-se necessário, ainda, solicitar às municipalidades restantes via e-mail tais documentos, totalizando um universo de 39 (ou 76,5\% dos 51 municípios da Região pesquisada) PMEs completos obtidos.

Após efetuadas todas as tentativas de obtenção dos PMEs da Região Administrativa de Marília, os 39 documentos coletados foram explorados, sistematizados e, por fim, analisados, com base na análise de

\footnotetext{
${ }^{7}$ Em relação aos outros 22 municípios restantes, só estava disponível na página do MEC apenas a lei de criação do PME, desprovida do anexo correspondente.
} 
conteúdo (FRANCO, 2008) e à luz do referencial teórico norteador da pesquisa, incialmente construído a partir da pesquisa bibliográfica empreendida, conforme abordado na próxima seção do trabalho.

\section{DESENVOLVIMENTO}

Dos 39 PMEs colhidos e analisados pelo estudo em tela, observase a partir da Tabela 1 que: a expressiva maioria deles (32 ou 82\%) obteve aprovação dentro do prazo (até 24 de junho de 2015) estipulado pela Lei no 13.005/2014 (Arco Íris, Assis, Bastos, Bernardino de Campos, Campos Novos Paulista, Cândido Mota, Cruzália, Echaporã, Espírito Santo do Turvo, Fernão, Florínea, Garça, Herculândia, Ipaussu, João Ramalho, Júlio Mesquita, Lupércio, Maracaí, Marília, Óleo, Oscar Bressane, Ourinhos, Palmital, Pedrinhas Paulista, Quatá, Queiroz, Rinópolis, Salto Grande, Santa Cruz do Rio Pardo, São Pedro do Turvo, Tarumã e Vera Cruz); outros seis (ou 15,4\%) só vieram a ser aprovados após expirar o referido prazo, embora ainda dentro do limite anual de 2015 (Alvinlândia, Borá, Lutécia, Parapuã, Pompéia e Quintana); e apenas um (2,6\%) extrapolou de forma discrepante o prazo legalmente estabelecido, sendo aprovado somente no final de junho de 2016, ou seja, com um ano de atraso (Gália).

Tabela 1 - PMEs da Região Administrativa de Marília: aprovação e vigência

\begin{tabular}{|c|c|c|}
\hline Município & $\begin{array}{c}\text { Lei do atual PME } \\
\text { Aprovado }\end{array}$ & $\begin{array}{l}\text { Período de } \\
\text { vigência }\end{array}$ \\
\hline Alvinlândia & Lei $n=1.488$ de 05/08/2015 & Não especificado \\
\hline Arco-Íris & Lei no 0339 de 23/04/2015 & Não especificado \\
\hline Assis & Lei no 6.046 de 24/06/2015 & De 2014 a 2024 \\
\hline Bastos & Lei no 2.621 de 16/06/2015 & Não especificado \\
\hline Bernardino de Campos & Lei no 1.933 de $17 / 06 / 2015$ & De 2014 a 2024 \\
\hline Borá & Lei no 709 de 08/12/2015 & De 2015 a 2024 \\
\hline Campos Novos Paulista & Lei no 659 de 23/06/2015 & De 2015 a 2025 \\
\hline Cândido Mota & Lei $n^{\circ} 2.346$ de 19/06/2015 & De 2015 a 2025 \\
\hline Cruzália & Lei no 594 de 22/06/2015 & De 2015 a 2025 \\
\hline Echaporã & Lei no 1.872 de 17/06/2015 & De 2015 a 2025 \\
\hline Espírito Santo do Turvo & Lei no 759 de 24/06/2015 & De 2014 a 2024 \\
\hline Fernão & Lei no 793 de 22/06/2015 & De 2015 a 2025 \\
\hline Florínea & Lei no 559 de 16/06/2015 & De 2015 a 2025 \\
\hline Gália & Lei no 2.355 de $28 / 06 / 2016$ & De 2016 a 2026 \\
\hline
\end{tabular}




\begin{tabular}{|c|c|c|}
\hline Garça & Lei no 4.998 de 10/06/2015 & De 2015 a 2025 \\
\hline Herculândia & Lei no 2.942 de 23/06/2015 & De 2015 a 2025 \\
\hline Ipaussu & Lei no 145 de 26/05/2015 & De 2015 a 2025 \\
\hline João Ramalho & Lei $n^{0} 549$ de 17/06/2015 & De 2015 a 2025 \\
\hline Júlio Mesquita & Lei no 1.387 de $23 / 06 / 2015$ & Não especificado \\
\hline Lupércio & Lei no 44 de 23/06/2015 & De 2015 a 2025 \\
\hline Lutécia & Lei no 21 de 07/07/2015 & De 2015 a 2024 \\
\hline Maracaí & Lei no 2.076 de 19/06/2015 & Não especificado \\
\hline Marilia & Lei no 7.824 de 23/06/2015 & De 2015 a 2025 \\
\hline Óleo & Lei no 1.841 de 22/06/2015 & Não especificado \\
\hline Oscar Bressane & Lei no 1.349 de $23 / 06 / 2015$ & Não especificado \\
\hline Ourinhos & Lei no 6.227 de 11/06/2015 & De 2015 a 2025 \\
\hline Palmital & Lei no 2.695 de 24/06/2015 & De 2015 a 2025 \\
\hline Parapuã & Lei no 2.865 de $26 / 06 / 2015$ & De 2015 a 2025 \\
\hline Pedrinhas Paulista & Lei no 1.069 de 23/06/2015 & De 2015 a 2025 \\
\hline Pompéia & Lei no 2.625 de 22/12/2015 & De 2015 a 2025 \\
\hline Quatá & Lei no 2.946 de 19/06/2015 & Não especificado \\
\hline Queiroz & Lei no 1.030 de 19/06/2015 & De 2015 a 2025 \\
\hline Quintana & Lei no 2.194 de 03/11/2015 & Não especificado \\
\hline Rinópolis & Lei no 1.812 de 17/06/2015 & Não especificado \\
\hline Salto Grande & Lei no 1.570 de $16 / 06 / 2015$ & De 2015 a 2025 \\
\hline Santa Cruz do Rio Pardo & Lei no 2.885 de 24/06/2015 & De 2015 a 2024 \\
\hline São Pedro do Turvo & Lei no 2.258 de $23 / 06 / 2015$ & Não especificado \\
\hline Tarumã & Lei no 1.168 de 23/06/2015 & De 2015 a 2025 \\
\hline Vera Cruz & Lei no 2.986 de 22/06/2015 & De 2015 a 2024 \\
\hline
\end{tabular}

Fonte: Elaboração própria.

Pela Tabela 1 constata-se, ainda, que os PMEs em análise majoritariamente (28 ou 71,8\%) explicitam em suas respectivas leis de criação e/ou anexo os anos de início e término de sua duração, ao passo que outros onze (ou 28,2\%) apresentam omissão acerca de tal aspecto.

Preponderantemente (22 ou 56,4\%), os PMEs das municipalidades vinculadas à Região Administrativa de Marília apresentam vigência decenal correspondente ao período de 2015 a 2025 (Campos Novos Paulista, Cândido Mota, Cruzália, Echaporã, Fernão, Florínia, Gália, Garça, Herculândia, Ipaussu, João Ramalho, Lupércio, Marília, Ourinhos, Palmital, Parapuã, Pedrinhas Paulista, Pompéia, Queiroz, Salto Grande, Santa Cruz do Rio Pardo, Tarumã, e Vera Cruz).

Entretanto, verifica-se, também, que alguns PMEs apresentam datação de vigência equivocada: de 2014 a 2024 (Assis, Bernardino de Campos e Espírito Santo do Turvo), o que pode indicar uma tentativa de reprodução em âmbito local da estruturação e conteúdo do plano federal, numa perspectiva de cumprimento mais burocrático do planejamento educacional municipal, tal qual foi constatado por Silva e Oliveira (2016) ao analisarem uma 
amostra de 14 PMEs de municípios situados no noroeste do estado de São Paulo; e de 2015 a 2024 (Borá e Lutécia), período que sequer atinge a duração total de dez anos prevista para todos os Planos educacionais subnacionais.

Cumpre destacar que todos os PMEs em questão tiveram a respectiva vigência iniciada antes mesmo da aprovação do PEE de São Paulo, cujo considerável atraso da sua elaboração/tramitação, além de deixar os municípios paulistas desprovidos de uma "referência territorial" mais próxima do que a nacional para se "espelhar", fragiliza o planejamento educacional sistêmico e pode comprometer a plena consecução das metas nacionalmente fixadas para o decênio.

Aliás, dentre os fundamentos ou referenciais para os planos de educação, Bordignon (2014, p. 35) ressalta justamente a visão sistêmica. Em suas palavras:

- visão sistêmica: um plano de educação, seja nacional, estadual ou municipal, além da contextualização em sua dimensão própria, deve ser referenciado, conectado na dimensão da nacionalidade, do todo nacional, ou seja: os diferentes planos não podem ser concebidos como sistemas fechados, mas abertos e articulados, trocando energias entre si, estabelecendo a sinergia no todo. É o espírito constitucional do regime de colaboração, que implica a definição de responsabilidades comuns, próprias e compartilhadas dos sistemas de ensino no todo nacional.

Como bem enfatiza a publicação "O Plano Municipal de Educação: caderno de orientações", elaborada pelo MEC em 2014 para auxiliar as municipalidades na importantíssima e inadiável tarefa de elaboração dos seus PMEs:

\begin{abstract}
Não se trata apenas de uma exigência legal: sem planos subnacionais formulados com qualidade técnica e participação social que os legitimem, o PNE não terá êxito. Os Planos Estaduais de Educação (PEEs) precisam ser imediatamente produzidos, debatidos e aprovados em sintonia com o PNE. E os Planos Municipais (PMEs), da mesma maneira que devem ser coerentes com o PNE, também devem estar alinhados aos PEEs dos estados a que pertencem. Para o cidadão, o PNE e os planos de educação do estado e do município onde ele mora devem formar um conjunto coerente, integrado e articulado para que seus direitos sejam garantidos e o Brasil tenha educação com qualidade e para todos. (BRASIL, 2014b, p.6, grifos nosso).
\end{abstract}

Não obstante a dissintonia temporal e desalinhamento dos PMEs ao tardio PEE paulista, estes constituem-se em instrumento de suma importância para o planejamento e gestão das políticas públicas educacionais no âmbito das instâncias municipais.

Como sabiamente aponta Bordignon (2009, p. 92): 
Quando o município não tem plano fica à mercê de ações episódicas que, mesmo planejadas caso a caso, representam improvisações. Sem plano municipal não há visão de Estado nas ações, não há caminho a percorrer, mas apenas passos ao sabor das circunstâncias de cada Governo.

Diante do longo histórico de descontinuidades dos planos e políticas educacionais no Brasil, mesmo depois de aprovados

[...] é importante que os planos de educação municipais sejam também foco de estudos e acompanhamento, pois não estão livres de ser manipulados e de servir a propósitos que não a garantia de uma escola pública, laica e de qualidade para todos (SILVA; MURANAKA, 2017, p. 244).

Portanto, uma vez aprovados e vigentes os PMEs no âmbito das localidades jurisdicionadas à Região Administrativa de Marília, o desafio premente consiste em implementar, monitorar e avaliar tais planos.

Além de estipular monitoramento contínuo e avaliações periódicas acerca da execução e cumprimento das metas e estratégias do PNE 20142024 e de seus similares em nível estadual, distrital e municipal (Art. 5o e Art. $7^{\circ}$, $\S^{\circ} 3^{\circ}$ ), a Lei $n^{\circ}$ 13.005/2014 foi além do PNE I e avançou ao definir com maior precisão as instâncias responsáveis pela realização de tal processo. No caso dos municípios, as instâncias seriam:

- Secretaria Municipal de Educação;

- Comissão de Educação da Câmara ou a própria Câmara;

- Conselho Municipal de Educação;

- Fórum Municipal de Educação (OLIVEIRA et al., 2016, p. 31).

Dos 39 PMEs perscrutados, a quase totalidade deles (38 ou $97,4 \%)$ prevê explicitamente sistemáticas de monitoramento e avaliação, em claro alinhamento ao preconizado pela Lei do PNE vigente e documento orientador do MEC (BRASIL, 2014b) concernente à temática. Em contrapartida, somente um (ou 2,6\%) se furta a fazer tal menção.

Daquele montante de 38 PMEs com previsão de monitoramento e avaliação do plano local, em seis (15,8\%) deles registra-se alusão a tais ações exclusivamente no corpo da lei de criação do PME, em outro (1 ou 2,6\%) a referência se faz presente unicamente no anexo da lei (o plano propriamente dito) e, na absoluta maioria ( 31 ou $81,6 \%$ ) deles as menções ao monitoramento e avaliação dos planos subnacionais comparecem tanto no corpo da lei quanto no seu respectivo anexo. 
A propósito, em 18 (ou 47,4\%) deles nota-se, inclusive, a existência de seção específica no anexo do PME destinada à temática em abordagem, predominantemente denominada de "Acompanhamento e Avaliação do Plano", o que sugere certa dificuldade das municipalidades correspondentes "[...] para se afastar do modelo metodológico adotado na construção do PNE 2001-2010 [...]" (MENEZES; SOUZA, 2018, p. 627).

No que se refere ao monitoramento dos PMEs, é possível identificar que em cerca de metade (19 ou 48,7\%) das fontes documentais examinadas não há determinação de sua periodicidade. Entretanto, tal qual o recomendado pelo Caderno de Orientações editado pelo MEC (BRASIL, 2014b), outra parte significativa (16 ou 41\%) dos PMEs analisados define uma regularidade anual, seguida por 4 (ou 10,3\%) cuja opção temporal adotada é a bienal.

No que tange à periodicidade prevista para a realização das avaliações dos planos educacionais, no conjunto dos PMEs analisados observa-se que ela varia de um a cinco anos, a saber: anual (4 ou 10,3\%); bienal ( 13 ou $33,3 \%$ ); trienal (3 ou $7,7 \%$ ); quadrienal $(7,7 \%)$; quinquenal ( 11 ou $28,2 \%$ ); além de 5 (ou 12,8\%) PMEs que não fizeram qualquer alusão temporal relativa à avaliação do planejamento decenal municipal.

Se por um lado, a prevalência da avaliação bienal (13 ou 33,3\%) nos planos pesquisados destoa da orientação federal de realizá-la trienalmente (BRASIL, 2014b), por outro, tal

[...] temporalidade julga-se de maior produtividade para esse tipo de planejamento educacional, pois permitem, em um espaço de dez anos, maior número de intervenções, embora demandando, em tempo mais reduzidos, maior atenção sobre o acompanhamento da implantação do plano por parte do poder público e da sociedade civil local (SOUZA; ALCÂNTARA, 2016, p. 207).

Ademais, avaliações mais longevas, como a quinquenal (11 ou $28,2 \%$ ), podem ser contraproducentes em caso de uma possível necessidade de replanejamento substancial, pois uma "[...] uma avaliação na metade da vigência, ou no final [do plano, pouco contribui] para corrigir o rumo perdido" (BORDIGNON, 2014, p. 47).

Quanto às instâncias responsáveis pelo monitoramento e avaliação dos PMEs, os documentos examinados fazem majoritária referência ao Conselho Municipal de Educação (CME) (27 ou 69,2\%) e à Secretaria Municipal de Educação (SME) ou órgão equivalente (25 ou $64,1 \%$ ) como principais condutores de tal processo em nível local. Deste modo, divergindo positivamente dos achados de outro estudo (SOUZA; ALCÂNTARA, 2016) que 
tomou por base empírica dez PMEs de localidades fluminenses para examinar o papel do CME na discussão, elaboração, acompanhamento e avaliação dos mesmos, os números apresentados aqui indicam claramente uma centralidade exercida compartilhadamente entre CME e SME, configurando-se num grande avanço ao superar a costumeira tendência de concentrar a referida responsabilidade tão somente nas mãos do órgão executivo do sistema municipal de ensino e alijar o correspondente órgão colegiado da mencionada atribuição.

Ao reconhecer o potencial do CME no controle social das políticas públicas educacionais locais, uma vez que constitui-se em espaço privilegiado para a participação da sociedade civil na sua gestão, Monlevade (2004, p. 40) pontua que:

O papel de dar o comando, de coordenar a elaboração, de executar as ações necessárias à construção e posterior execução e avaliação do PME é da Secretaria Municipal de Educação (SME), [...] mas, havendo um Conselho Municipal de Educação, com poder normativo ou somente consultivo, é dele o papel primordial de inspirar, incentivar, colaborar e orientar todo o processo de elaboração, execução e avaliação do PME.

Não obstante o aludido avanço, em dissintonia quanto aos espaços institucionais definidos em nível nacional para a efetuação do monitoramento e da avaliação, os PMEs sob exame secundarizam a participação do Fórum Municipal de Educação (FME) (13 ou 33,3\%) e da Câmara Municipal de Vereadores (7 ou 17, 9\%), de modo a deslegitimar sua competência no tocante a tal empreitada.

Espaços de interlocução entre a sociedade civil e o governo e fundamentais para a efetivação da gestão democrática da educação (DOURADO, 2017), os FMEs "[...] assumem um importante papel na medida em que articulam os diferentes anseios com vistas ao planejamento participativo na formulação dos planos decenais de educação e em seu monitoramento" (SCAFF; OLIVEIRA; ARANDA, 2018, p. 138).

Cabe destacar, ainda, que parte expressiva (18 ou 46,2\%) das municipalidades pesquisadas, na contramão das orientações federais, não faz qualquer menção nos seus PMEs à constituição de Comissão de Monitoramento e Avaliação dos planos locais, cuja existência é imprescindível para o êxito do processo em tela.

\section{CONSIDERAÇÕES FINAIS}

O estudo desenvolvido acerca da previsão de monitoramento e avaliação nos PMEs da Região Administrativa de Marília permitiu revelar aspectos tanto positivos quanto preocupantes, conforme retrospectiva e 
sinteticamente recuperado: constatou-se que a quase totalidade das municipalidades investigadas estabeleceu explicitamente nos seus respectivos PMEs sistemáticas de monitoramento e avaliação, em claro alinhamento ao PNE vigente, tanto no corpo da Lei do PME quanto no seu anexo (o plano propriamente dito). Entretanto, observou-se, também, que cerca de metade dos PMEs não determinou a periodicidade concernente ao monitoramento e neles prevalece a avaliação bienal, destoando, portanto, das orientações oficiais federais atinentes ao referido processo de monitoramento (anual) e avaliação (trienal) dos planos subnacionais de educação. Evidenciou-se, ainda, que, de forma análoga as ações de monitoramento e avaliação propostas para o plano de âmbito nacional, os PMEs fazem referência aos CMEs e SMEs (ou órgão equivalente) como principais instâncias responsáveis pela condução de tal processo em nível local, mas, simultânea e majoritariamente, secundarizam a correspondente participação do Fórum Municipal de Educação e da Câmara Municipal de Vereadores, cuja frequência de menções é consideravelmente menor. Por fim, revelou-se que parte expressiva das municipalidades, na contramão dos documentos federais, não faz qualquer alusão nos seus PMEs à constituição de Comissão de Monitoramento e Avaliação dos planos locais, cuja existência é crucial para o êxito do processo em tela.

Depreende-se, portanto, a partir do conjunto das fontes documentais analisadas, que se por um lado as municipalidades abrangidas pelo presente estudo muito já caminharam para que seus PMEs venham a ter sua implementação efetivamente monitorada e avaliada, por outro permanece ainda o desafio de se contemplar um maior envolvimento da sociedade e dos múltiplos canais representativos nas questões atinentes ao planejamento e gestão da educação municipal, a fim de que esta possa plenamente alcançar a tão almejada gestão democrática e a qualidade social.

Indubitavelmente, para que os PMEs se distanciem cada vez mais de um mero cumprimento burocrático e se configurem verdadeiramente como epicentro das políticas educacionais locais, a ampla e permanente mobilização e participação da sociedade civil organizada se faz imprescindível.

\section{REFERÊNCIAS}

ALVES, Edson Ferreira. Universalização da aprovação de planos de educação por estados e municípios: o que vem depois? In: XXVIII Simpósio de Política e Administração da Educação, 2017, João Pessoa, PB. Anais...UFG: ANPAE, 2017. v. 45. p. 2307-2318. 
ANTUNES, Marina Ferreira de Souza. Plano Municipal de Educação de Uberlândia - monitoramento e avaliação: desafios para a valorização da carreira docente. Revista Educação e Políticas em Debate, v. 8, n. 1, p. 19-36, jan./abr. 2019.

BORDIGNON, Genuíno. Gestão da educação no município: sistema, conselho e plano. São Paulo: Editora e Livraria Instituto Paulo Freire, 2009.

. Caminhar da educação brasileira: muitos planos, pouco planejamento. In: SOUZA, Donaldo Bello de; MARTINS, Angela Maria (Orgs.). Planos de Educação no Brasil: planejamento, políticas, práticas. São Paulo: Edições Loyola, 2014. p. 29-53.

BRASIL. Lei no 13.005, de 25 de junho de 2014. Aprova o Plano Nacional de Educação e dá outras providências. Diário Oficial da União, Brasília, DF, 26. jun. 2014. Seção 1, p.01. 2014a.

- Ministério da Educação. Secretaria de Articulação com os Sistemas de Ensino (SASE). O Plano Municipal de Educação: caderno de orientações. Brasília: MEC, 2014b.

DOURADO, Luiz Fernandes. Plano Nacional de Educação: o epicentro das políticas de estado para a educação brasileira. Goiânia: Editora da Imprensa Universitária/ANPAE, 2017.

DOURADO, Luiz Fernandes; GROSSI JUNIOR, Geraldo; FURTADO, Roberval Ângelo. Monitoramento e avaliação dos planos de educação: breves contribuições. RBPAE, v. 32, n. 2, p. 449 - 461 mai./ago. 2016.

FRANCO, Maria Laura Puglisi Barbosa. Análise de conteúdo. 3. ed. Brasília: Líber Livro, 2008.

MARCONI, Marina de Andrade; LAKATOS, Eva Maria. Metodologia do trabalho científico: procedimentos básicos, pesquisa bibliográfica, projeto e relatório, publicações e trabalhos científicos. 7. ed. 6. reimpr. São Paulo: Atlas, 2011.

MENEZES, Janaína Specht da Silva; SOUZA, Donaldo Bello de. Monitoramento e avaliação nos Planos Estaduais de Educação consoantes ao novo PNE. PRÓ-POSIÇÕES, v. 29, p. 614-639, 2018.

MONLEVADE, João Antônio. A importância do Conselho Municipal de Educação na elaboração, implantação e acompanhamento da execução do Plano Municipal de Educação. In: BRASIL. Ministério da Educação. Secretaria de Educação Básica. Programa Nacional de Capacitação de Conselheiros 
Municipais de Educação Pró-Conselho: caderno de referência. Brasília, DF: MEC/SEB, 2004.

NASCIMENTO, Gilvânia da Conceição; GROSSI JUNIOR, Geraldo; PEREIRA, Jhonata Moreira. Planos Municipais de Educação: perfil dos municípios que não possuíam plano municipal de educação no segundo ano de vigência da Lei n. 13.005/14. Revista Exitus, Santarém/PA, Vol. 7, n. 1, p. 108-130, jan./abr. 2017.

OLIVEIRA, João Ferreira et al. Planos Estaduais, Distrital e Municipais de Educação: monitoramento e avaliação - Caderno Temático ANPAE 4. Camaragibe, PE: CCS Gráfica e Editora, 2016.

SCAFF, Elisangela Alves da Silva; OLIVEIRA, Marli dos Santos de; ARANDA, Flávia Paula Nogueira. Planejamento educacional e poder local na elaboração dos planos municipais de educação. Quaestio, Sorocaba, SP, v. 20, n. 1, p. 133-147, abr. 2018.

SCAFF, Elisangela Alves da Silva; OLIVEIRA Marli dos Santos de. Planos decenais de educação: sistematização do monitoramento e avaliação nos cenários estadual e municipal. Série-Estudos, Campo Grande, MS, v. 23, n. 47, p. 141-162, jan./abr. 2018.

SILVA, Leandro Vitoriano da; OLIVEIRA, Maria Eliza Nogueira. O Plano Municipal de Educação: da autonomia construída à autonomia decretada. Revista Teias, Rio de Janeiro, v. 17, n. 47, p. 107-123, out./dez. 2016.

SILVA, Mariana Aparecida da; MURANAKA, Maria Aparecida Segatto. Uma análise do processo de elaboração do plano municipal de educação de Rio Claro-SP. Educação: Teoria e Prática, Rio Claro, SP, v. 27, n.55, p.244-261, maio/ago. 2017.

SOUZA, Donaldo Bello de; ALCÂNTARA, Alzira Batalha. O lugar dos Conselhos Municipais de Educação nos PMEs relativos ao PNE 2001-2010. Revista Educação em Questão, Natal, v.54, n.40, p. 191-219, jan./abr. 2016. 


\title{
PARCERIAS INSTITUCIONAIS COM VISTAS À EDUCAÇÃO EMPRESARIAL: Relato da formação da Escola Prática de Negócios no âmbito do Programa de Desenvolvimento Empresarial
}

\author{
CARVALHO NETO, Silvio \\ Doutor em Administração - USP \\ Centro Universitário Municipal de Franca - Uni-FACEF \\ silvio@facef.br \\ SARTÓTIO, Danila \\ Especialista em Gestão de Pessoas - Uni-FACEF \\ ACIF-Franca \\ danilasartorio@acifranca.com.br
}

\section{INTRODUÇÃO}

O propósito do presente artigo é apresentar um relato de caso de uma experiência de parceria institucional feita entre o Centro Universitário Municipal de Franca (Uni-FACEF) e a Associação do Comércio e Indústria de Franca (ACIF-Franca). A parceria teve como fruto um projeto cujo escopo é a educação empresarial. O relato apresenta aspectos do desenvolvimento e da formação do projeto educacional, batizado de Escola Prática de Negócios (EPN). A EPN é um curso de extensão e especialização oferecido à comunidade empresarial da cidade de Franca-SP, que faz parte de um programa educacional desenvolvido denominado Programa de Desenvolvimento Empresarial (PDE).

O embrião deste programa ocorreu pelas discussões do setor de Desenvolvimento Empresarial da ACIF-Franca. Este setor encaminhou proposta para a presidência que constava no interesse da formação de um curso focado para a gestão empresarial, em que os participantes poderiam cursar temas relevantes para o dia a dia nas empresas. O diferencial da proposta seria atender pessoas que tivessem ou não realizado cursos de graduação anteriormente. Esta proposta, embasada em pesquisas realizadas, virou realidade a partir da parceria da associação comercial com o Centro Universitário Municipal de Franca, autarquia municipal situada na cidade de Franca. Este artigo, deste modo, procura responder à questão que investiga quais aspectos deste programa podem ser considerados exitosos e quais as principais dificuldades e desafios da parceria para os próximos anos. Além disso, procura investigar a opinião dos egressos sobre o desempenho do programa e da parceria. 
O método utilizado nesta investigação é exploratório, por meio de pesquisa em dados secundários, documentais e bibliográficos, e primários, mediante a utilização de técnica exploratória qualitativa (GIL, 2007; MARCONI e LAKATOS, 2001). Por meio da investigação empírica e do entendimento de projetos relacionados à educação corporativa, procura-se ressaltar o papel de um programa de educação empresarial voltado para micro e pequenos empresários, em um momento de profunda e dinâmica alteração no ambiente de negócios. $\mathrm{O}$ trabalho pode ser enquadrado como relato de experiência, à medida que apresenta uma história informativa e como ela se reflete em situações gerais de seu escopo (SANTORO, 2010).

\section{HISTÓRICO DO PROGRAMA}

A concepção inicial para a realização do Programa de Desenvolvimento Empresarial (PDE) começou com a análise dos resultados obtidos a partir de um trabalho de conclusão de curso de uma especialização em gestão feita por uma colaboradora da ACIF Franca, ao final do ano de 2012. O objetivo principal desse trabalho foi buscar evidências, por meio de pesquisas quantitativas e, principalmente, qualitativas, da importância e da efetividade de um programa de educação empresarial voltado para micro e pequenos empresários.

A pesquisa teórica realizada foi feita por meio impresso e eletrônico, e abordou o empreendedorismo e a relação do grau de escolaridade e conhecimento dos empreendedores para a gestão planejada do negócio. $\mathrm{Na}$ pesquisa documental foram utilizadas fontes como tabelas estatísticas e estudo de pesquisas anteriores sobre $o$ assunto.

Foi feita, ainda, uma a pesquisa de campo, com abordagens qualitativa e quantitativa para a coleta de informações. Naquele momento foi realizado um grupo de estudo que foi composto por empresários participantes dos grupos de um projeto da ACIF à época, chamado de Projeto Empreender, programa gerado pela associação para o desenvolvimento de empresários, que se reuniam semanalmente em busca de ferramentas de gestão e troca de experiências entre os participantes do grupo.

Os grupos do Projeto Empreender tinham um total de 150 participantes, todos empresários da cidade. Foi então estabelecida a realização de uma pesquisa junto a estes empresários, com vistas à captar às demandas por aperfeiçoamento profissional e por cursos de capacitação para os membros dos grupos. Dos 150 empresários, que participavam dos grupos, 77 responderam à pesquisa solicitada. Este grupo de respostas foi considerado como relevante, por representar uma fatia que já era atendida pela associação e que vinha mostrando, através de dados concretos, que o programa 
desenvolvido especificamente para micro e pequenos empresários atingiam resultados significativos para fortalecimento, crescimento e desenvolvimento dessas empresas e para a economia da cidade.

Este trabalho inicial de investigação teve como conclusão que os empresários, atendidos pelo Programa Empreender, enxergavam de uma forma diferente a importância de, não somente se qualificar, mas também trazer conhecimento para a sua equipe. Numa escala de 1 a 10 de importância, $66 \%$ responderam o grau 10 em relação a criação de um treinamento focado em gestão, e isso sinalizava à instituição que os empresários ainda tinham interesse em aprender mais sobre diversos assuntos do meio empresarial.

Por meio dos resultados desta pesquisa inicial, foi então possível afirmar que havia uma carência de informação e formação para os empresários da cidade, que desejavam se qualificar e entender melhor o negócio que administravam. A fatia pesquisada reforçava que mesmo sendo um grupo que já vinha trabalhando há algum tempo com a educação empresarial, os empresários sentiam a necessidade de buscar por mais conhecimento. Nota-se que, na época, o mercado para estas empresas estava cada vez mais exigente e com constantes mudanças paradigmáticas. Durante a pesquisa, muitos empresários revelaram que, além das ferramentas de gestão, eles precisavam aprender novos conhecimentos, e novos cursos de capacitação seriam interessantes para que eles ficassem atentos às mudanças que aconteciam no ambiente empresarial.

Diante dos dados obtidos com a pesquisa de prospecção, chegou-se a conclusão de que era fundamental uma continuidade, por parte da associação, do oferecimento de programas de capacitação educacional para os empresários associados da instituição, e esta conclusão abriu caminhos para novas pesquisas e novos projetos na área educacional.

Como sequência natural do processo inicializado com as pesquisas realizadas no ano anterior, logo no início do ano de 2013, foi apresentada à presidência da instituição, pelo setor de Desenvolvimento Empresarial da ACIF, uma proposta para a formação de um curso totalmente focado na gestão empresarial, em que os participantes poderiam cursar temas relevantes para o dia a dia na empresa. $O$ diferencial da proposta seria que este curso poderia ser formado por pessoas que tivessem ou não cursado algum curso de graduação anteriormente, e o que mudaria era o tipo de certificado emitido ao final do curso. Essa proposta foi embasada na pesquisa realizada, quando foi levantada a situação de que muitos empresários que procuravam o aperfeiçoamento educacional ainda não tinham feito nenhum curso de graduação, mas estavam dispostos a frequentar cursos de extensão, práticos e com ensinamentos que poderiam ser aplicados no cotidiano empresarial. 
Em 2013, a diretoria da instituição acabou por não ter intenção de levar a proposta adiante, e a ideia do curso ficou sem seguimento até o ano de 2016. Neste ano, houve mudança na presidência da instituição, e o novo presidente que tomava posse, comprou a ideia do projeto e forneceu apoio para que este seguisse em direção à sua concreta realização.

Um novo desafio surgiu pela frente da associação comercial, que foi procurar o parceiro educacional adequado que atenderia às demandas da instituição. A ideia inicial de parceria seria àquela que pudesse proporcionar a realização de um curso voltado para a prática empresarial, dinâmico e com as características de flexibilização em termos dos ingressantes (para incluir nãograduados), que até então não existia oferecido na cidade, com público, formato, dia de aplicação das aulas, totalmente fora do convencional.

A ACIF Franca prospectou algumas instituições do Estado de São Paulo, realizou reuniões e analisou várias possibilidades de parcerias com IES. Algumas destas reuniões foram realizadas entre integrantes da associação comercial e os representantes do Centro Universitário Municipal de Franca (UNIFACEF, 2019), que elaborou uma proposta com o esboço do projeto, que foi posteriormente aceita e acordada por ambas as partes, e associação acabou por escolher o Uni-FACEF como instituição parceria ideal para a execução do projeto.

Ao longo dos últimos meses de 2016, integrantes da ACIF e do Uni-FACEF estabeleceram a parceria formal, e começaram a desenvolver os detalhes do projeto, como grade e estrutura, determinação dos professores que se envolveriam no projeto, a após meses de elaboração, no começo de 2017 foi lançada a primeira turma do curso que foi denominado Programa de Desenvolvimento Empresarial (PDE), curso inserido no projeto chamado de Escola Prática de Negócios (EPN).

Logo após o lançamento do projeto, o desafio das duas instituições foi o de comercializar algo que ainda não existia no mercado. Havia muitas dúvidas por parte dos associados, até mesmo para os próprios membros da ACIF, como, por exemplo, a dinâmica das aulas, se daria certo a presença de pessoas com grau diferente de conhecimento na mesma sala de aula, dentre outras incertezas.

A primeira turma foi fechada rapidamente, o que pode ser considerado como um sucesso logo nos primeiros meses de lançamento do Programa. Nos anos seguintes, 2018 e 2019, foram fechadas mais duas turmas na sequência. A divulgação dos alunos da primeira turma, a certeza da efetividade do curso na aplicação prática nas organizações, levou novamente as duas instituições a conseguir fechar as duas turmas nos anos seguintes, com relativo esforço de conscientização da importância do projeto para os associados, novos e antigos. 


\section{CARACTERÍSTICAS DO PROGRAMA}

O objetivo central da Escola Prática de Negócios (EPN) é capacitar o profissional de empresas associadas da ACIF com uma formação qualificada, a partir de uma moderna e prática visão da administração empresarial, que permite o conhecimento e a interação das diversas áreas da empresa associada, por meio do oferecimento do Programa de Desenvolvimento Empresarial (PDE). O PDE foca na prática dos negócios nas principais áreas funcionais de gestão empresarial. O público alvo do curso é formado por empresários, gestores e empreendedores que desejam aperfeiçoar os conhecimentos em tornos dos processos gerenciais e administrativos das empresas (ACIFRANCA, 2019).

Ao final do curso, é concedido ao discente considerado aprovado, em relação a notas e frequência, certificado de Conclusão de Curso de Extensão, emitido em conjunto por ACIF e Uni-FACEF.

As avaliações são realizadas nas salas de aula e nos laboratórios de informática localizados na Unidade II do Centro Universitário Municipal de Franca, de acordo com a necessidade de cada docente, ao final de cada disciplina, de acordo com os critérios específicos de cada docente, com as notas variando de 0 (zero) a 10 (dez), sendo a nota 7 (sete) como a nota mínima exigida para aprovação na disciplina. É considerado aprovado no módulo, com direito a certificado, o discente que obtiver aprovação em todas as disciplinas do respectivo módulo.

As aulas são ministradas nas manhãs dos dias de semana, terçafeira, nas primeiras e terceiras turmas, e quartas na segunda turma, das $8 \mathrm{~h} 00$ às $12 \mathrm{~h} 00$. Há ainda uma carga horária de uma hora por encontro presencial destinada ao complemento de atividades em sala de aula, com o uso do Ambiente Virtual de Aprendizagem para a leitura prévia de material disponibilizado pelo docente com vistas ao nivelamento de conteúdo. O corpo docente do PDE é formado por doutores e mestres que atuam diretamente no mercado na área em que ministram aulas.

O calendário de aulas de cada turma tem início no mês de Fevereiro do primeiro ano de curso e término em Dezembro do ano seguinte, tendo ainda um período extra de seis meses para os já graduados, que optarem por fazer o módulo de Metodologia de Pesquisa Científica e o Trabalho de Conclusão de Curso, e os que realizarem este trabalho têm direito ao certificado de especialização. Há três meses de férias durante 0 ano corrente: Janeiro, Julho e Dezembro. A carga horária total do programa é de 360 horas. A duração em meses do curso é de aproximadamente 24 meses, 
sendo quatro meses para cada módulo. O curso é presencial, ou seja, tem uma exigência mínima de $75 \%$ de frequência para a aprovação final do discente.

Os módulos e os conteúdos das disciplinas são estruturados de forma que o discente possa conseguir cursar apenas parte do programa, quando o convier. No total o PDE é composto por sete módulos de 60 (sessenta) horas, cada um tendo três disciplinas de 20 (vinte) horas cada.

O módulo de Contabilidade e Gestão Financeira tem as seguintes disciplinas: Contabilidade para Decisões Comerciais, que apresenta os conceitos básicos e avançados de contabilidade para gestão; Administração Financeira no Comércio, que estabelece o conceito de administração de empresas com base na geração de valor, desenvolvendo a diferença de visão de curto e longo prazo, e estabelecendo a definição estratégica entre lucro e geração de caixa; e Gestão no Ambiente de Negócios, que estuda as organizações como sistemas e suas dimensões contextuais e estruturais.

O segundo módulo tem o foco no Direito Empresarial e na Gestão Trabalhista e Tributária. Suas disciplinas são: Direito Empresarial, com a análise de tópicos avançados de Direito Empresarial; Gestão Fiscal e Tributária, que aborda os conceitos básicos de planejamento tributário e casos de elisão e evasão fiscal; e Gestão de Passivos Trabalhistas, que trata dos conceitos básicos de folha de pagamento e gestão de passivos no setor de recursos humanos.

O terceiro módulo do primeiro ano de programa se chama Planejamento Organizacional, com as disciplinas: Planejamento Estratégico, que fornece uma visão geral do planejamento estratégico nas organizações; Ambiente de Negócios e Cenários, que discute os conceitos básicos para a análise do ambiente macroeconômico em que as instituições estão inseridas; e Análise Econômica de Investimentos, com o foco nos principais indicadores de gestão financeira, como risco, retorno; conceito de dinheiro no tempo, Valor Presente Líquido, Payback e Fluxo de Caixa, dentre outros.

O segundo ano começa com o módulo de Gestão de Marketing com as disciplinas: Planejamento e Gestão de Marketing, que levanta os conceitos de planejamento de marketing; Marketing e Vendas, que aborda as tendências de marketing e vendas e marketing de serviços e varejo; e Comunicação Empresarial e Pesquisa, que trata sobre a comunicação empresarial e a pesquisa de marketing.

Na sequência é oferecido o módulo de Gestão de Pessoas com as disciplinas: Gestão de Mudanças e de Competências, que aborda o papel do gestor nos processos de mudanças; Gestão de Recursos Humanos, Liderança e Gestão de Equipes, que traz os diversos modelos de gestão em 
pessoas; e Recrutamento e Seleção e Gestão de Carreiras, com o foco no recrutamento de pessoas e na gestão interna de evolução na carreira.

Por fim, o último módulo do segundo ano tem como abordagem o Planejamento Organizacional e o Empreendedorismo. Tem as disciplinas Empreendedorismo e Inovação, com foco no empreendedorismo e no caráter inovador que a administração atual de empresas deve exigir; Sustentabilidade e Responsabilidade Social, que apresenta temas de sustentabilidade e responsabilidade social, e Gestão de Informações Gerenciais, com temas sobre a administração de sistemas e tecnologia de informação.

Caso o discente tenha anteriormente cursado o terceiro grau, ele poderá fazer o último módulo de Metodologia de Pesquisa Científica, para realizar o Trabalho de Conclusão de Curso e ter o direito ao certificado de especialização. Este módulo tem as seguintes disciplinas: Pesquisa Qualitativa; Estatística e Pesquisa Quantitativa e Seminários de Trabalhos de Conclusão. A estrutura de módulos e disciplinas está exposta em detalhes na Figura 1.

\begin{tabular}{|c|c|}
\hline Módulos & Disciplinas \\
\hline $\begin{array}{l}\text { Módulo de Contabilidade e Gestão } \\
\text { Financeira }\end{array}$ & $\begin{array}{l}\text { Contabilidade para Decisões Comerciais } \\
\text { Administração Financeira no Comércio } \\
\text { Gestão no Ambiente de Negócios }\end{array}$ \\
\hline $\begin{array}{l}\text { Módulo de Direito Empresarial, Gestão } \\
\text { Trabalhista e Tributária }\end{array}$ & $\begin{array}{l}\text { Direito Empresarial } \\
\text { Gestão Fiscal e Tributária } \\
\text { Gestão de Passivos Trabalhistas }\end{array}$ \\
\hline Módulo de Planejamento Organizacional & $\begin{array}{l}\text { Planejamento Estratégico } \\
\text { Ambiente de Negócios e Cenários } \\
\text { Análise Econômica de Investimentos }\end{array}$ \\
\hline Módulo de Gestão de Pessoas & $\begin{array}{l}\text { Gestão de Mudanças e de Competências } \\
\text { Gestão de RH, Liderança e Gestão de Equipes } \\
\text { Recrutamento e Seleção e Gestão de Carreiras }\end{array}$ \\
\hline Módulo de Gestão de Marketing & $\begin{array}{l}\text { Planejamento e Gestão de Marketing } \\
\text { Marketing e Vendas } \\
\text { Comunicação Empresarial e Pesquisa }\end{array}$ \\
\hline $\begin{array}{l}\text { Módulo de Planejamento Organizacional e } \\
\text { Empreendedorismo }\end{array}$ & $\begin{array}{l}\text { Empreendedorismo e Inovação } \\
\text { Sustentabilidade e Responsabilidade Social } \\
\text { Gestão de Informações Gerenciais }\end{array}$ \\
\hline Módulos de Pesquisa Científica & $\begin{array}{l}\text { Pesquisa Qualitativa } \\
\text { Estatística e Pesquisa Quantitativa } \\
\text { Seminários de Trabalhos de Conclusão }\end{array}$ \\
\hline
\end{tabular}

Fonte: Elaborado pelos autores.

\section{RESULTADOS E DESAFIOS DO PROGRAMA}

Foram formadas, até 2019, três turmas da Escola Prática de Negócios. A primeira turma teve um total de 32 alunos ingressantes, a segunda 43 e a terceira tem um total de 34 alunos, o que é está dentro da média de ingressantes para cursos de extensão da IES. O índice de evasão destas turmas pode ser considerado baixo, quando comparado com o padrão de cursos de especialização Lato Sensu da instituição, ficando abaixo de $10 \%$. A 
gestão administrativa e o acompanhamento dos alunos ficam a cargo da ACIF, enquanto toda a gestão acadêmica fica sob a responsabilidade do Uni-FACEF.

Após cada disciplina é feita uma avaliação do docente e da disciplina, por parte dos discentes, em termos de itens como preparação de aula, conteúdo, cordialidade do docente, dentre outros. Todos os itens são avaliados em uma escala de 0 (zero) a 10 (dez), sendo zero atribuído para uma avaliação negativa e o dez para uma alta avaliação positiva. A média das notas aos docentes e disciplina dada pelas turmas da EPN foi 9,46 (em 10 pontos possíveis). Esse resultado mostra quantitativamente uma opinião de satisfação do corpo discente em relação ao programa.

As instituições também buscaram saber qualitativamente dos alunos o que eles pensavam a respeito do curso e de suas formações. Por meio de breves entrevistas com os alunos, foi possível obter diversas declarações a respeito de como o programa foi benéfico para a atuação dos empresários no dia a dia. A Figura 2 apresenta relatos e opiniões sobre o curso de alguns alunos que já se formaram e também que ainda estão cursando 0 programa.

Figura 2 - Relatos e Opiniões de Alunos do PDE-EPN 
"Me encantei pelo curso logo no inicio e, para mim, está sendo uma experiência impar. Aplicando o que aprendo aqui, consigo oxigenar minha empresa. Estamos começando um trabalho na empresa a fim de incentivar nossos funcionários a participarem também deste aprendizado."

“O curso é surpreendente e obrigatório para qualquer empreendedor: seja para aprender conceitos e ferramentas administrativas ou para aprimorar conhecimentos. O ensino é focado na prática, com uma estrutura de professores impecável, tornando o empreendedor muito mais consciente de suas obrigações, direitos e importância no cenário econômico."

“Em 2017, completei 30 anos de graduação e me presenteei com a Escola Prática de Negócios. A interação com outros profissionais, com os professores e a diversidade de cargos e atividades estão me trazendo uma nova visão profissional."

"Esta tem sido uma experiência reveladora. Minha visão so-
bre a minha própria empresa mudou a partir das necessida-
des que o curso me mostrou que eu tinha. Por exemplo: eu
não tinha conhecimento algum sobre tributação e delegava
completamente ao escritório de contabilidade. Com as au-
las, aprendi a argumentar e as conversas com o contador e a
equipe de sistemas ficaram muito mais alinhadas."

"Tive a oportunidade de ter aulas com um corpo docente fantástico, que aumentou o meu conhecimento e me forneceu ferramentas de gestão para aplicações práticas no dia a dia."

"Um ponto interessante da Escola Prática de Negócios é o
networking formado. Tenho colegas da indústria, da área de
cosméticos, mercado financeiro e diversas outras áreas que
expõem suas necessidades em sala de aula. Para mim, que
trabalho com o desenvolvimento de softwares, esse subsi-
dio é maravilhoso."

“Não é um curso comum ou uma possibilidade de certificação em pós-graduação, é muito mais que isso! Para mim, significou uma quebra de paradigmas."

Fonte: elaborado pelos autores. 
Como observado nos relatos apresentados na Figura 02, a opinião é de que o curso foi extremamente relevante para os participantes. Houve uma forte união entre a turma, e um aproveitamento em relação aos conceitos de relacionamento, mudanças de paradigmas e aquisição de novos saberes. A Figura 3 apresenta algumas imagens do networking dos alunos da primeira turma da EPN.

Com base nas análises da coordenação do PDE e no depoimento dos alunos é possível considerar como aspectos positivos da formação do Programa a formação das turmas com elevado número de alunos, a avaliação positiva que a maioria dos alunos fez do programa e o retorno institucional obtido pelas instituições parceiras. Em termos de desafios, os discentes demandaram a continuidade das turmas, com o oferecimento de novos módulos e disciplinas, e muitos também necessitam de repor módulos perdidos por motivos de ausência e/ou insuficiência de notas para aprovação.

Figura 3 - Imagens do networking dos alunos da primeira turma do PDE-EPN

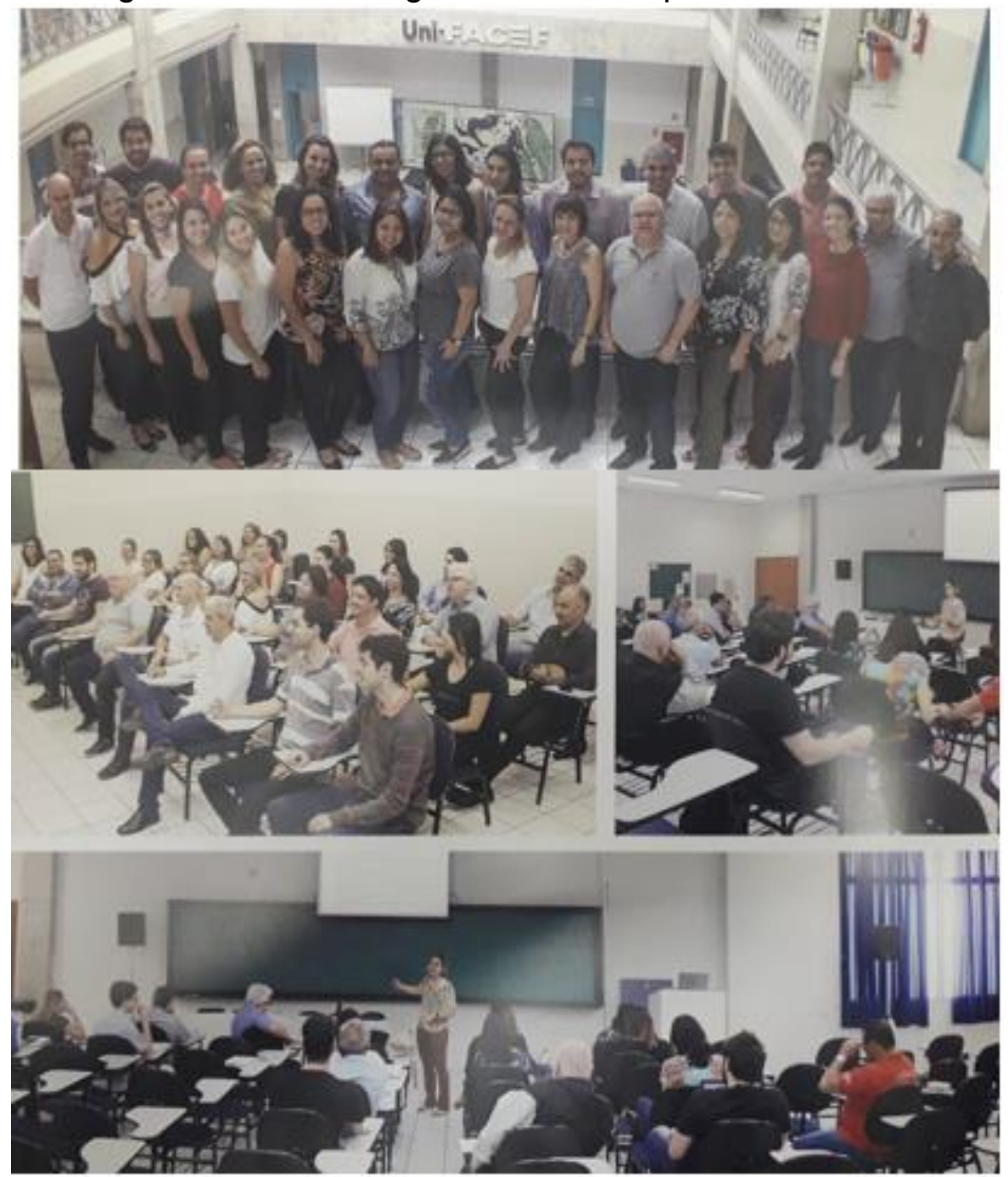

Fonte: EPN, 2019. Adaptado pelos autores. 


\section{CONSIDERAÇÕES FINAIS}

O objetivo deste trabalho foi o de apresentar o relato de caso da criação, evolução, resultados e desafios do Programa de Desenvolvimento Empresarial, que consiste no oferecimento de um curso batizado de Escola Prática de Negócios, feito em parceria firmada entre o Centro Universitário Municipal e a Associação do Comércio e Indústria de Franca-SP. Este curso é de extensão, oferecido em módulos separados, mas também pode ser de especialização para aqueles discentes que já possuem diplomas de cursos de graduação e completam a fase de produção acadêmica-científica do programa.

Foi apresentado um histórico e a evolução da concepção e realização do programa, em termos das ações que levaram à parceria institucional. Além disso, foram apresentadas todas as características e a estrutura do curso oferecido. Os aspectos do programa que podem ser considerados exitosos são: a formação de turmas com um elevado número de alunos, a avaliação qualitativa e quantitativa que os alunos fizeram do programa e o retorno institucional que o programa apresentou para as instituições parceiras. As dificuldades e desafios da parceria nos próximos anos consistem principalmente na continuidade das turmas, na evolução das disciplinas, na criação de novos módulos e na gestão administrativa de reposição de módulos.

Acredita-se que este relato de experiência é relevante, pois permite que aspectos da parceria sejam aplicados em outras regiões do país que tenham as mesmas características encontradas na cidade de Franca, especialmente, um alto número de empresas, uma universidade local e uma associação comercial, fortes e atuantes na comunidade.

\section{REFERÊNCIAS}

ACIFRANCA. Escola Prática de Negócios, 2019. Acesso em 19/08/2019.

Disponível em: http://www.acifranca.com.br /SITE/ conteudo/escola-pratica-denegocios-inicia-suas-atividades-com-aula-de-boas-vindas.html

EPN. Folder de Divulgação Escola Prática de Negócios, 2019.

GIL, A. C. Como elaborar projetos de pesquisa. 4. ed. São Paulo: Atlas, 2007

MARCONI, M. A.; LAKATOS, E. M. Metodologia do trabalho científico: preceitos básicos, pesquisa bibliográfica, projeto e relatório, publicações e trabalhos científicos. 6. ed. São Paulo: Atlas, 2001. 
SANTORO, F. Apresentação de Metodologia da Pesquisa Científica, Programa de Pós-Graduação em Informática - UNIRIO, 2010.

UNIFACEF. Pós-graduação Especializações. Acesso em 25/08/2019.

Disponível em: http://pos.unifacef.com.br/pt/ 


\title{
PRÁTICAS DE GESTÃO ESCOLAR DA EDUCAÇÃO BÁSICA: a estrutura da equipe gestora escolar da rede pública municipal de ensino em Franca/SP - perspectivas, atribuições e articulação do trabalho
}

\author{
VILAÇA, Andrea Marqueti \\ Mestre em Planejamento e Análise de Políticas Públicas - UNESP/Franca \\ amarqueti@gmail.com \\ COLOMBINI, Flávia Pinheiro da Silva \\ Mestre em Planejamento e Análise de Políticas Públicas - UNESP/Franca \\ flaviapscolombini@hotmail.com
}

\section{INTRODUÇÃO}

Este trabalho tem como objetivo caracterizar a atuação da equipe gestora das escolas públicas municipais pertencentes à Secretaria Municipal de Educação da cidade de Franca/SP. Nas escolas municipais, a equipe gestora é composta pelo diretor escolar, coordenador pedagógico, orientador educacional, pedagogo e pedagogo da sala de recursos multifuncionais, tornando-se um diferencial frente a muitos municípios que não possuem uma equipe com essa configuração para a atuação em conjunto na tomada de decisões técnico-administrativas e pedagógicas.

A composição de uma equipe gestora formada por cinco profissionais especialistas da educação favorece uma gestão escolar mais democrática, na medida em que descentraliza as decisões, mas, ao mesmo tempo exige articulação, interação e integração entre as diferentes áreas de atuação, dada a complexidade educacional que demanda as organizações escolares e as atribuições de cada gestor.

As instituições escolares configuram-se em ambientes de contínua renovação do conhecimento, com o ideal de proporcionarem ensino efetivo, de acordo com o saber produzido socialmente e pautadas no desenvolvimento contínuo para alunos, professores, funcionários e gestores. A educação constitui-se então em processos formais e organizados, com a finalidade prevista na LDB Art. $2^{\circ}$. Lei 9.394/1996 de "promover o desenvolvimento pleno do educando, sua preparação para o exercício da cidadania e sua qualificação para o trabalho".

Sabe-se que nesse contexto, o conhecimento da realidade e das novas demandas, como a tecnologia da informação e comunicação, as relações e influências globalizadas, os cenários socioculturais, políticos e educativos, fazem emergir a necessidade de readequação de seus Projetos 
Políticos Pedagógicos, a atualização dos currículos seguindo as orientações da nova Base Nacional Curricular Comum8, exigindo maior empenho e desempenho de seus profissionais, que sentem a necessidade de renovar-se e melhorarem continuamente suas intervenções, tendo o aluno como centro de todas as suas atuações.

Parte-se então do princípio que o trabalho em educação exige profissionais que tenham competências para realizar em seus contextos educacionais as readequações das demandas emergentes e de acordo com as necessidades em que atuam no interior das escolas.

Sendo assim, parte-se da apresentação da composição das equipes gestoras das escolas públicas municipais de Franca, como uma equipe de especialistas em educação que prezam pelo bom andamento da rotina escolar e que buscam diversas alternativas para se alcançar o êxito no processo educacional e na formação integral do aluno.

Para isso, partimos da análise de documentos oficiais da prefeitura e da Secretaria da Educação que determinam a composição e a atuação desses gestores nas escolas, dentre eles o Regimento Escolar, a Lei municipal 01/95 e o Estatuto dos Profissionais do Magistério do Município. Também utilizamos como base para essa análise, parte dos estudos específicos, realizados anteriormente pelas autoras, que tratam especialmente sobre a atividade profissional de alguns desses gestores

Conclui-se, portanto, que a adoção desse modelo organizacional de gestão escolar, implantado pela Secretaria de Educação do município, se apresenta como um modelo de relevância, pois toma como perspectiva a crescente complexidade do trabalho pedagógico e administrativo nos sistemas de ensino e o compromisso com a formação integral de qualidade de todos os seus alunos.

\section{A COMPOSIÇÃO DA EQUIPE GESTORA E SUA ATUAÇÃO}

Conforme destaca Luck (2009), a gestão escolar é pautada, principalmente, na figura do diretor escolar, da supervisão ou coordenação pedagógica, da orientação educacional e da secretaria da escola, de forma que todos devem ser atuantes da equipe gestora da escola. A autora também afirma que, pelo princípio de gestão democrática, o processo de gestão escolar

\footnotetext{
${ }^{8}$ A Base Nacional Comum Curricular (BNCC) é um documento de caráter normativo que define o conjunto orgânico e progressivo de aprendizagens essenciais que todos os alunos devem desenvolver ao longo das etapas e modalidades da educação básica. Disponível em http://basenacionalcomum.mec.gov.br/ Acesso em 1 set. 2019
} 
também deve incluir a participação ativa dos professores, funcionários e da comunidade escolar para a efetivação da garantia de qualidade do processo educacional para todos os alunos.

Para Luck (2009), a gestão escolar é a responsável por gerir a dinâmica cultural da escola, articulando as diretrizes e políticas educacionais com a implementação de seu projeto político pedagógico da escola, partindo dos princípios da democracia e métodos que criem condições para se criar um ambiente autônomo, onde a participação e o compartilhamento na tomada de decisões sejam práticas frequentes, buscando a efetivação dos resultados sempre com o acompanhamento e avaliação de todo o processo.

\begin{abstract}
A gestão escolar constitui uma dimensão e um enfoque de atuação em educação, que objetiva promover a organização, a mobilização e a articulação de todas as condições materiais e humanas necessárias para garantir o avanço dos processos socioeducacionais dos estabelecimentos de ensino orientados para a promoção efetiva da aprendizagem dos alunos, de modo a torná-los capazes de enfrentar adequadamente os desafios da sociedade complexa, globalizada e da economia centrada no conhecimento. Por efetividade entende-se, pois, a realização de objetivos avançados, em acordo com as novas necessidades de transformação socioeconômico-cultural, mediante a dinamização do talento humano, sinergicamente organizado. (LUCK, 2009, p. 24).
\end{abstract}

A mobilização e a articulação dos educadores que atuam no interior das escolas públicas municipais da rede de ensino de Franca-SP, principalmente em suas equipes gestoras, é o foco desse estudo.

Franca é um município brasileiro localizado na região nordeste do Estado de São Paulo. De acordo com dados do Instituto Brasileiro de Geografia e Estatística (IBGE), em 2018, a cidade possui uma população estimada de aproximadamente 350 mil pessoas. Possui uma economia predominantemente industrial, destacando-se no setor calçadista e coureiro, sendo reconhecida nacionalmente como a capital do calçado. Também se destaca pela relevante produção agrícola, como pertencente a umas das mais importantes regiões produtoras de café do país, a região da Alta Mogiana. Com um Produto Interno Bruto (PIB) per capita anual de $\mathrm{R} \$ 24.679,09$ é considerada uma cidade com bom desenvolvimento econômico e humano, possuindo um Índice de Desenvolvimento Humano Municipal (IDHM) de 0,78, segundo dados do IBGE, retirados do site do instituto.

Igualmente positivos também são os dados e índices educacionais do município. O percentual de escolarização entre crianças e 
adolescentes de 6 a 14 anos é de 98,2\%9 (IBGE, 2010) e o Índice de Desenvolvimento de Educação Básica (IDEB10) em 2017 para os alunos concluintes do $5^{\circ}$ ano do ensino fundamental foi de 7,2, uma média acima da média do Estado de São Paulo, que foi de 6,6 e do Brasil que foi de 5,6, segundo dados coletados no site do Instituto Nacional de Ensino e Pesquisa (INEP).

A Constituição Federal Brasileira define em seu artigo 30, inciso $\mathrm{VI}$, que compete aos municípios "[...] manter, com a cooperação técnica e financeira da União e do Estado, programas de educação infantil e de ensino fundamental." (BRASIL, 1988). Atendendo a este dispositivo constitucional, em Franca, a Secretaria Municipal de Educação (SME) foi instituída para atender e organizar seu próprio sistema de ensino, definindo normas e procedimentos pedagógicos adequados à realidade do município.

A Lei Complementar 01/95, que dispõe sobre o plano de cargos do Serviço Público Municipal de Franca e sua estrutura organizacional, determina que

Art. 9o - A Secretaria Municipal de Educação tem por finalidade implantar, coordenar e executar a política municipal de educação e tem por competências:

1. Implantação e coordenação da política municipal de educação;

2. Desenvolvimento de programas de Educação Infantil, Ensino Fundamental e Médio;

3. Supervisão da educação em geral, abrangendo o Ensino Fundamental, Médio, Educação de Jovens e Altos e Educação Especial, além de outras que a lei determinar.

4. Definir as diretrizes para a elaboração do Plano Municipal de Ensino.

5. Promover o desenvolvimento do ensino, incentivando a integração entre a escola e a comunidade.

6. Cuidar da construção e preservação de todos os próprios voltados para a área da Educação;

7. Emitir atos normativos, portarias ou resoluções, visando ao bom desenvolvimento dos projetos;

8. Formular políticas e estratégias para a inovação e modernização dos ambientes e das tecnologias educacionais;

9. Executar outras atividades correlatas. (FRANCA, 1995).

\footnotetext{
${ }^{9}$ De acordo com o IBGE, este percentual segue o seguinte cálculo: "[população residente no município de 6 a 14 anos de idade matriculada no ensino regular/total de população residente no município de 6 a 14 anos de idade] x 100."

10 O IDEB apesar de ser questionado por alguns estudiosos da área de Política Educacional, ainda, é o principal indicador de medição da qualidade da educação básica no Brasil. O índice sintetiza em um único indicador dois conceitos importantes para aferir a qualidade do ensino no país, fluxo (taxa de aprovação dos alunos) e a aprendizagem (resultados de desempenho nas avaliações da educação básica aplicadas pelo Instituto Nacional de Ensino e Pesquisa INEP). A média do IDEB varia de 0 a 10 sendo calculada a partir dos dados de aprovação escolar, obtidos no Censo Escolar, fornecidos pelas escolas anualmente com os resultados de desempenho obtidos na Prova Brasil (no caso de escolas e municípios) aplicada nos $5^{\circ} \mathrm{s}$ e 9ํㅗ anos do Ensino Fundamental.
} 
Em cada gestão administrativa, a Secretaria Municipal de Educação (SME) assume novas metas, missão e compromissos com a sociedade. Sendo assim, este departamento, em sua atual gestão (20172020), definiu como sua atribuição:

[...] planejar e executar as ações educacionais no âmbito o Sistema Municipal de Ensino, por meio da promoção de políticas públicas de democratização e acesso ao ensino público gratuito e de qualidade nos níveis da Educação Infantil, Ensino Fundamental, nas modalidades de Educação Especial e Educação de Jovens e Adultos. Tem como objetivos centrais preparar os educandos para o exercício da cidadania; valorizar os profissionais da educação; garantir autonomia didática e de gestão às unidades escolares; promover a integração entre a escola, a família e a comunidade; contribuir para ampliação do acesso, garantia de permanência e sucesso das crianças com idade escolar obrigatória. (FRANCA, 2018).

A SME afirma ainda que sua missão é "Servir a comunidade e a família garantindo educação de qualidade, assegurando acesso, permanência e sucesso de todos os alunos, promovendo uma cultura para a paz e a justiça, num processo de melhoria contínua." (FRANCA, 2018).

Portanto,

"[...] é através da Secretaria Municipal de Educação que as linhas de ação, a coordenação, a avaliação e os contínuos acompanhamentos são definidos, assim como a maioria das políticas públicas educacionais relacionadas à gestão escolar das escolas municipais." (MARQUETI, 2016, p. 80).

A missão defendida pela SME foi elaborada, nos anos de 2005 2007, quando houve uma reestruturação desta pasta, com o apoio de diversos atores da sociedade civil e busca ser consolidada pela equipe de gestão pedagógica que se forma a cada gestão administrativa/política na cidade. As determinações da SME sobre as metas da educação municipal e sobre a organização do trabalho nas escolas têm grande influência sobre a construção das funções dos profissionais que atuam nas instituições de ensino do município.

Convencionou-se, na SME desde os anos de 2005, a denominar os cargos de diretor, coordenador pedagógico, orientador educacional, pedagogos e pedagogo da Sala de Recursos Multifuncionais como Equipe Gestora. Em decorrência desta ideia, a concepção vigente desde essa época até os dias atuais é claramente expressa no que menciona Luck (2015, p. 87) sobre a gestão "a crescente complexidade do trabalho pedagógico levou à instituição de funções diferenciadas nos sistemas de ensino e nas escolas, sendo elas atribuídas a profissionais diversos". Porém a formação e composição da Equipe Gestora não encontra nenhuma regulamentação em lei ou regimento. A Lei 01/95 se encontra, portanto, desatualizada em relação à 
realidade vivenciada nas escolas do município, pois não contempla a existência, nem a descrição dos cargos de diretor de escola e do pedagogo da Sala de Recursos Multifuncionais 11.

Outro documento que caracteriza o quadro de pessoal das escolas públicas municipais de Franca é o Regimento Escolar, que apesar de não ter força legal, constitui-se em um conjunto de regras e normas que definem a organização administrativa e pedagógica das escolas, estabelecendo, por exemplo, os direitos e deveres daqueles que compõem o ambiente escolar.

De acordo com o artigo 29 do Regimento Escolar, fazem parte do quadro de pessoal das escolas municipais em Franca: inspetor de aluno, secretário de escola e escriturário, pertencentes ao quadro de apoio educacional e administrativo; ajudante geral e servente merendeiro, estes pertencente ao quadro operacional de apoio. Professor I, professor I de Educação Musical, professor I de Educação Especial, professor II de Educação Física, diretor de Escola, coordenador pedagógico, orientador educacional, pedagogo e supervisor de ensino (lotado na SME), todos estes pertencentes ao quadro do magistério. A disposição desses cargos segue os critérios da Lei Municipal 01/95, com exceção do cargo de diretor de escola, que não é previsto nesta lei, apenas no Estatuto do Magistério.

Genericamente, podemos definir a responsabilidade de cada gestor que compõe a equipe gestora das escolas públicas municipais de Franca da seguinte maneira:

Diretor escolar: Gestor responsável por administrar e gerir todas as atividades educacionais e administrativas na unidade escolar; garantir 0 funcionamento pleno da escola como organização social, estimulando a participação dos pais e comunidade na vida escolar, bem como nos colegiados e associações, respeitando e aplicando as determinações legais nacionais, estaduais e locais, em todas as suas ações.

Coordenador pedagógico: Gestor responsável pela organização e supervisão dos planos escolares em conjunto com os professores; participa de consultas bem como avalia e reajusta a programação curricular e desenvolve a formação continuada dos professores, nas reuniões pedagógicas semanais; conduz o Planejamento Anual da unidade escolar e as estatísticas e intervenções sobre os resultados escolares e de avaliações externas.

Pedagogo: Gestor responsável pela assistência aos educadores e atendimentos pedagógicos aos alunos, realizando pesquisas, aplicando testes pedagógicos, avaliando questionários, entrevistas e demais técnicas

\footnotetext{
${ }^{11} \mathrm{O}$ cargo de diretor está previsto como pertencente ao quadro do magistério apenas na Lei 4.972 de 1998, que institui o Estatuto do Magistério Público Municipal de Franca.
} 
disponíveis; busca a modernização dos métodos utilizados pelo pessoal docente; divulga experiências e materiais relativos à educação, para estimular o aprimoramento do processo pedagógico. Costuma-se mencionar que este profissional se especializa nas dificuldades de aprendizagem dos alunos, com o olhar também para as fragilidades do ensino que muitas vezes ocasiona a falsa ideia de que os alunos é que possuem dificuldades na aprendizagem.

Pedagogo das Salas de Recursos Multifuncionais: Gestor responsável por identificar, elaborar e organizar serviços e recursos pedagógicos de acessibilidade, considerando as necessidades específicas dos alunos, público-alvo da educação especial; elaborar e executar plano de atendimento educacional especializado, organizando os atendimentos (individual, grupo ou acompanhamento em sala de aula) e o número de atendimentos aos alunos. Esta função foi criada pelo Município de Franca desde a Política de Inclusão12 delineada pelo Ministério da Educação, no ano de 2009, de encaminhar para as escolas públicas materiais e formação para as denominadas salas de recursos. $O$ ingresso do profissional para esta função se dá mediante o concurso para pedagogo e no ato da atribuição, há a vertente pedagogo ou pedagogo sala de recursos.

Orientador educacional: Gestor responsável por desenvolver o processo de orientação educacional na Unidade Escolar, em cooperação com os professores, a família e a comunidade; participar do processo de identificação das características básicas da comunidade e alunos e realizar atendimentos aos alunos e familiares, dando devolutivas e orientações ao corpo docente.

Com a finalidade de preparar estes profissionais para um trabalho articulado, coletivo, em equipe e evitar que este avanço na educação municipal não causasse o individualismo de cada função, gerando dispêndio de recursos, de energias e sem resultados positivos, investiu-se e investe-se até hoje em formações continuadas oferecidas pela própria SME, pois como afirma Luck (2015, p.96) "a complexidade educacional demanda organizações escolares bem articuladas mediante ação conjunta e colaborativa" e ainda ressalta que onde "as pessoas atuam de maneira mais feliz e produtiva, e realizam seu potencial, quando o fazem de forma colaborativa, pela troca $e$ compartilhamento".

A Lei Federal 9.394/96 - Lei de Diretrizes e Bases da Educação Nacional (LDB) - trata sobre a formação continuada dos profissionais do magistério, em alguns dos seus artigos. $\mathrm{O}$ artigo $62, \S 1^{\circ}$ afirma que "A União,

12 Sobre o Programa de Implantação das Salas de Recursos Multifuncionais, maiores esclarecimentos encontram-se disponíveis em <http://portal.mec.gov.br/pnpd/194-secretarias112877938/secad-educacao-continuada-223369541/17430-programa-implantacao-de-salas-derecursos-multifuncionais-novo $>$ Acesso em 27 dez 2015 
o Distrito Federal, os Estados e os Municípios, em regime de colaboração, deverão promover a formação inicial, a continuada e a capacitação dos profissionais de magistério." (BRASIL, 1996).

\section{A mesma lei, no artigo 67, também determina que}

Os sistemas de ensino promoverão a valorização dos profissionais da educação, assegurando-lhes, inclusive nos termos dos estatutos e dos planos de carreira do magistério público:

[...]

II - aperfeiçoamento profissional continuado, inclusive com licenciamento periódico remunerado para esse fim;

[...]. (BRASIL, 1996).

Porém, em Franca, atualmente, este artigo da referida lei não é totalmente contemplado, pois o município ainda não possui plano de carreira específico para o magistério e, portanto, não prevê licença remunerada para os profissionais da educação que queiram se especializar.

As leis municipais norteadoras do magistério também tratam sobre a formação continuada dos profissionais da educação da rede pública de ensino. Sobre o treinamento dos servidores públicos municipais, a Lei Complementar 01/95 determina:

Art. 21 - Fica institucionalizado como atividade permanente, o treinamento dos servidores, tendo como objetivos:

I. criar e desenvolver mentalidade, hábitos e valores necessários ao digno exercício da função pública;

II. capacitar o servidor público municipal da administração direta para o desempenho de suas atribuições específicas, orientando-se no sentido de obter os resultados desejados pela Administração;

III. estimular o rendimento funcional, criando condições propícias para o constante aperfeiçoamento dos servidores;

IV. integrar os objetivos de cada servidor no exercício de suas atribuições à finalidade última da Administração como um todo.

Art. 22 - O treinamento será de dois tipos:

I - De integração, tendo como finalidade integrar o servidor no ambiente de trabalho e desenvolver valores necessários ao exercício da função pública; e

II - De formação, que objetiva dotar o servidor de maiores conhecimentos e técnicas referentes às atribuições que desempenha, mantendo-o permanentemente atualizado e preparando-o para a execução de tarefas mais complexas.

$\S 1^{\circ}$ - O treinamento será ministrado:

a. preferentemente pela Prefeitura, com a utilização de servidores de seu quadro;

b. mediante encaminhamento de servidores para cursos e estágios realizados por entidades especializadas, sediadas ou não no município;

c. através da contratação de especialistas ou entidades especializadas. (FRANCA, 1995). 
Da mesma forma, o Estatuto do Magistério também prevê, no Artigo $4^{\circ}$, inciso II o "[...] aperfeiçoamento profissional continuado, inclusive com licenciamento periódico remunerado para esse fim [...]", porém, como já foi dito acima esta lei atualmente não é respeitada, pois ao profissional da educação não é concedido licenciamento remunerado para seu aperfeiçoamento e especialização.

O Plano Municipal de Educação da cidade (PME) também prevê a formação continuada dos profissionais da educação do município, propondo como objetivo principal:

[...] subsidiar o trabalho pedagógico das escolas em seus aspectos teóricos e práticos, por meio de reuniões de formações continuadas e assessorias aos profissionais da educação atuantes em cada unidade escolar. Percebe- se a necessidade de estudos constantes para 0 aprimoramento pessoal e profissional no que diz respeito à educação de qualidade e de orientações por meio de assessorias, sempre garantindo a continuidade da compreensão da proposta pedagógica da Secretaria Municipal de Educação de Franca com formações e informações atualizadas. (FRANCA, 2015, p. 44).

Sendo assim, a formação continuada dos educadores da rede pública municipal fica a cargo da Secretaria Municipal de Educação (SME). A SME possui a Divisão de Gestão Educacional - Setor de Formação Continuada, responsável por oferecer formação continuada a todos os segmentos de professores e especialistas que atuam na escola.

[...] composto por profissionais concursados e que são designados para desenvolver 0 trabalho de formação, orientação e monitoramento das funções e ações, associando a teoria e a prática do contexto escolar, favorecendo a qualificação e instrumentalizando o profissional para que seja capaz de desenvolver com qualidade os serviços prestados, contribuindo assim para a formação integral de todos os alunos, dentro de seu nível de atuação. (MARQUETI, 2016, p. 83).

Como parte da formação continuada dos profissionais da educação da rede, nas escolas municipais de Franca são realizadas, semanalmente, as Reuniões de Estudos Pedagógicos (REPs) com todos os docentes e equipe gestora para estudos, planejamento de ações e avaliação do trabalho pedagógico. Com duração de 50 minutos, essas reuniões são, geralmente, dirigidas pelo coordenador pedagógico com o apoio da equipe gestora e atendem ao que é determinado pela Lei 01/95, quanto ao tipo de treinamento de integração do servidor ao ambiente de trabalho, desenvolvendo os valores necessários ao exercício de sua função. Na atual gestão municipal, outra parte da REP é realizada na modalidade a distância - REP online - 
atendendo ao artigo 87, $\S 3^{\circ}$, inciso III da LDB que determina que Distrito Federal, Estados, Municípios e União devem "realizar programas de capacitação para todos os professores em exercício, utilizando também, para isto, os recursos da educação a distância". (BRASIL, 1996). Na REP online, os professores devem cumprir as leituras e atividades propostas na plataforma, totalizando $2 \mathrm{~h}$ /aula semanais obrigatórias de estudos pedagógicos.

Mediante essa estrutura de recursos humanos disponíveis na unidade escolar, em especial ao detalhamento realizado sobre os profissionais que compõem a equipe gestora escolar, a estrutura de gestão e estrutura de formação pedagógica oferecida pela Secretaria Municipal de Educação, ressalta-se a importância da reflexão sobre o papel de cada membro da equipe gestora e a necessidade de continuidade no processo de profissionalização destas funções, oportunizando e oferecendo formação continuada em serviço, incentivando a continuidade das formações acadêmicas e os cursos de extensão.

\section{CONSIDERAÇÕES FINAIS}

Apresentar a estrutura organizacional da Secretaria Municipal de Educação de Franca, em especial das equipes que compõe a gestão escolar foi foco desse estudo objetivando proporcionar ao leitor uma visão dessa forma de organização que visa a integração de uma equipe a favor de um trabalho que privilegie uma visão ampliada de educação e da formação dos alunos.

Toda instituição escolar possui uma estrutura de organização interna para conseguir atingir suas finalidades, determinar papéis e responsabilidades. Geralmente, esta estrutura é prevista no Regimento Interno da escola e/ou em legislação específica estadual ou municipal, refletindo a concepção de organização e gestão vigente. Libâneo (2013) assegura que dificilmente na estrutura organizacional, o ordenamento e a disposição dos setores e funções que asseguram o funcionamento da escola conseguem escapar de certa burocracia, principalmente porque as escolas públicas integram uma rede de ensino ou um sistema educacional mais complexo.

No caso da Rede Municipal de Franca, por não ter seu sistema próprio de ensino, esta vincula-se à Secretaria de Estado da Educação de São Paulo no que diz respeito às legislações educacionais e orientações de funcionamento, de forma geral. A partir desses parâmetros, cria e elabora suas próprias formas de organização e funcionamento, como por exemplo a estrutura citada nesse estudo, que trouxe a composição das equipes gestoras escolares - diretor, coordenador pedagógico, orientador educacional, pedagogo e pedagogo das salas de recursos multifuncionais. 
Para subsidiar a organização e atuação desses profissionais nas escolas, torna-se imprescindível o trabalho realizado pela Secretaria Municipal de Educação de formação continuada em serviço, com o objetivo maior de proporcionar clareza das atribuições de cada profissional, inclusive do conhecimento das determinações legais em relação ao cargo que se ocupa, definir metas e ações e sobretudo oportunizar uma maior articulação e integração dos especialistas da equipe gestora a fim de contribuir para o bom andamento da escola e para o melhor desenvolvimento da aprendizagem. Ressalta-se também que esse modelo de organização de equipe gestora escolar tem-se destacado como um diferencial importante da rede municipal de Franca, sendo dificilmente encontrada essa mesma composição em outros municípios e estados.

Sabe-se que a articulação e a integração desses profissionais configura-se em desafio diário, tendo no Diretor o líder responsável por conduzir a equipe no planejamento de suas atividades. Luck (2009, p. 12) ressalta que "nenhuma escola pode ser melhor que os profissionais que nela atuam. Sob essa perspectiva, busca-se uma estrutura de gestão escolar mais democrática, afinada com as diretrizes e políticas públicas educacionais implantadas na escola, onde as condições de compartilhamento na tomada de decisões ganhem espaço e efetividade.

Com essas questões apresentadas, espera-se uma gestão escolar que seja capaz de maximizar os resultados através da formação integral do educando, contribuindo não apenas com o processo de aprendizagem pedagógica dos alunos, mas também com sua formação social, emocional, solidária, democrática e humana.

\section{REFERÊNCIAS}

BRASIL. Constituição da República Federativa do Brasil 1988. Diário Oficial da União, Brasília, DF, 5 out. 1988. Disponível em: https://www.planalto.gov.br/ccivil_03/constituicao/constituicao.htm. Acesso em: 10 ago. 2018.

BRASIL. Lei n. 9394 de 20 de dezembro de 1996. Estabelece as diretrizes e bases da educação nacional. Diário Oficial da União, Brasília, DF, 23 dez. 1996. Disponível em: http://www.planalto.gov.br/ccivil_03/leis/L9394.htm. Acesso em: 22 abr. 2018.

COLOMBINI, Flávia Pinheiro da Silva. A prática do orientador educacional e - seu papel no cotidiano escolar na Rede Pública Municipal de Franca/SP. 2019. 134 f. Dissertação (Mestrado em Planejamento e Análise de Políticas 
Públicas) - Faculdade de Ciências Humanas e Sociais, Universidade Estadual Paulista "Júlio de Mesquita Filho", Franca, 2019.

FRANCA. Lei Complementar n. 01, de 24 de julho de 1995. Dispõe sobre o Plano de Classificação de Cargos do Serviço Público Municipal de Franca, sua estrutura organizacional, institui as tabelas de vencimentos e dá outras providências. Comércio da Franca, [25 jul. 1995]. Disponível em: https://franca.sp.leg.br/legislacao/lei-complementar-no-1-de-24-de-julho-de1995. Acesso em: 2 nov. 2018.

FRANCA. Lei n. 4. 972 de 11 de fevereiro de 1998. Institui o Estatuto do Magistério Público Municipal de Franca e dá outras providências. Comércio da Franca, [12 fev. 1998]. Disponível em: https://franca.sp.leg.br/legislacao/lei-no4972-de-11-de-fevereiro-de-1998. Acesso em: 2 nov. 2018.

FRANCA. Secretaria Municipal de Educação. Plano Municipal de Educação. Franca, 2015. Disponível em: https://www.franca.sp.gov.br/images/EDUCACAO/1INSTITUCIONAL/PLANO_MUNICIPAL/plano_municipal_da_educaao.pdf. Acesso em: 18 jul. 2018.

FRANCA. Secretaria Municipal de Educação. Regimento Escolar: educação infantil e ensino fundamental. Franca, 2017. (Separata).

FRANCA. Secretaria Municipal de Educação. Franca, 2018. Disponível em: https://www.franca.sp.gov.br/administracao-municipal/administracaodireta/educacao/apresentacao-educacao. Acesso em: 18 jul. 2018.

IBGE. Estatísticas: por cidade e estado: Franca: panorama. Rio de Janeiro, 2017. Disponível em: https://cidades.ibge.gov.br/brasil/sp/franca/panorama. Acesso em: 17 dez. 2018.

LIBÂNEO, José Carlos. Organização e gestão da escola - teoria e prática. São Paulo: Heccus, 2013.

LUCK, Heloísa. Dimensões de gestão escolar e suas competências. Curitiba: Editora Positivo, 2009.

MARQUETI, Andrea. Políticas de acesso ao cargo de diretor de escola pública da educação básica: novas perspectivas a partir da realidade do município de Franca/SP. 2016. 153 f. Dissertação (Mestrado em Planejamento e Análise de Políticas Públicas) - Faculdade de Ciências Humanas e Sociais, Universidade Estadual Paulista “Júlio de Mesquita Filho", Franca, 2016. 


\section{ÍNDICE}

\section{A}

ARANDA, Maria Alice de Miranda, 71,83

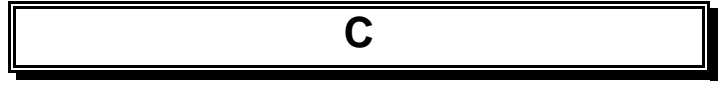

CARVALHO NETO, Silvio, 95 COLOMBINI, Flávia Pinheiro da Silva, 107, 117

\section{D}

DIAS, Matheus Henrique, 17

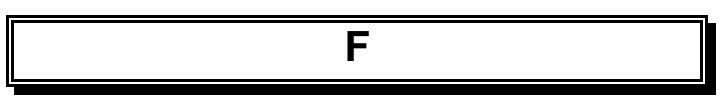

FINETTE, Carolina Rodrigues, 8

\section{M}

MALTA, Deise Aparecida Silva, 61

MALTA, Leticia Pereira, 32

MÁXIMO, Heliny de Carvalho, 61
MILITÃO, Silvio Cesar Nunes, 71, 83

\section{R}

ROCHA, Juliano Gomes da, 43

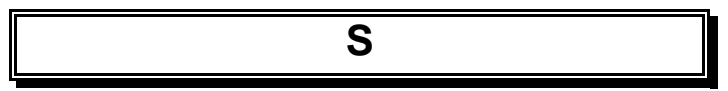

SARTÓTIO, Danila, 95

SILVA, Hilda Maria Gonçalves da, 8 SMITH, Marinês Santana Justo, 43 SOMMERHALDER, Aline, 61 SOUZA, Tatiana Noronha de, 32

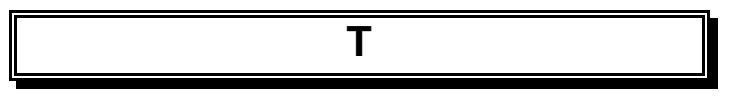

TOFFANO, Marcelo, 17

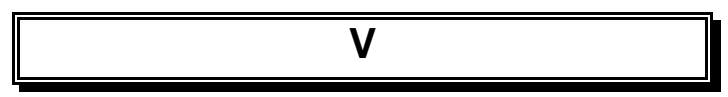

VILAÇA, Andrea Marqueti, 107 

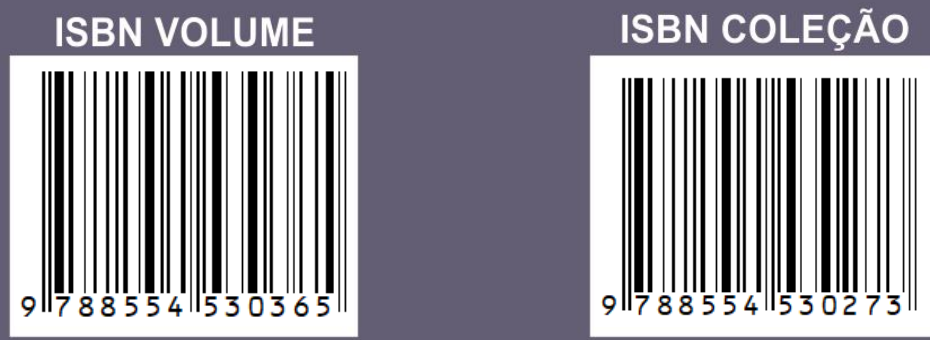

\section{8 | 163713.4688

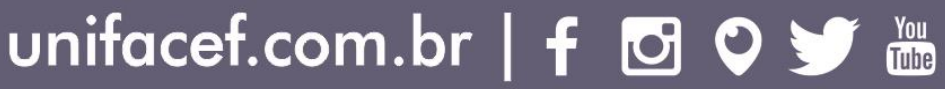 \\ 163706.8700 franca.unesp.br}

